\title{
The vitality and revitalisation attempts of the Mansi language in Khanty-Mansiysk
}

\author{
Csilla Horváth \\ A dissertation submitted for the degree of \\ Doctor of Philosophy at the \\ University of Szeged
}

Uralic Studies PhD Programme

Doctoral School in Linguistics

University of Szeged

Supervisors: Anna Fenyvesi, PhD.

Katalin Sipőcz, PhD.

Szeged, 2020 
És lássa, nem volt igaza. Én is ott voltam az ön művének előadásán; minden szavát úgy szívtam magamba, mint a mennyei mannát, s ha egyszer nyomtatva lesz, a biblia helyett fogom olvasni. De hogy elő nem adják többször, azt nem bánom. Ön uram, magának írta azt a darabot, meg még tíz embernek, akik közül öt még eztán fog megszületni. 
I would like to express my gratitude to all those who gave me support to complete this dissertation.

I would like to express my gratitude to certain representatives of the international society of railway workers, without whose help would not have been possible to carry out and to finance my studies and research 


\section{Table of contents}

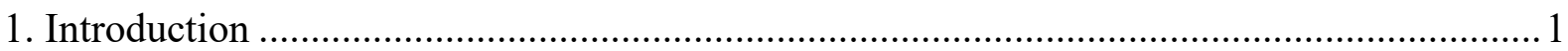

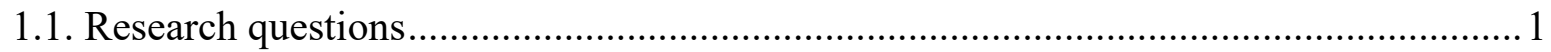

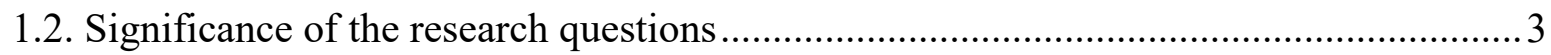

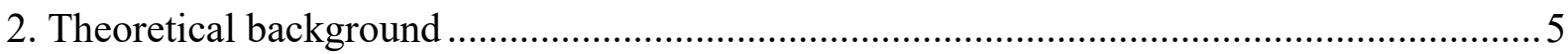

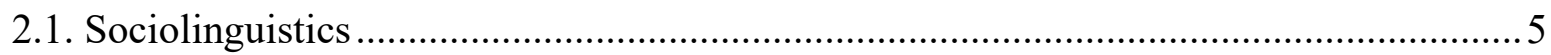

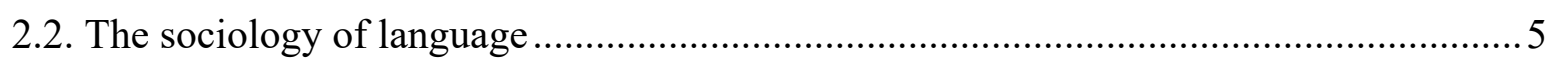

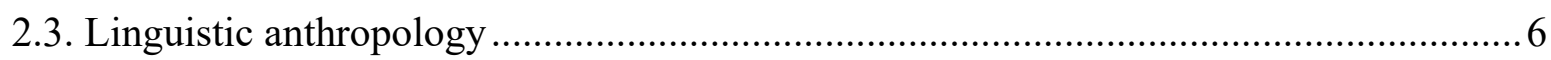

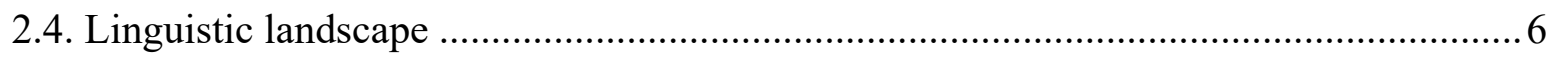

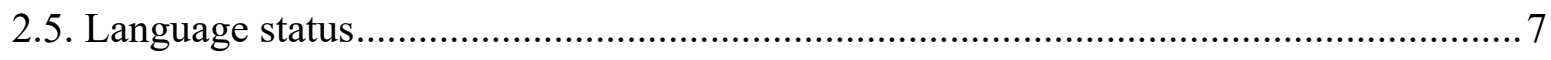

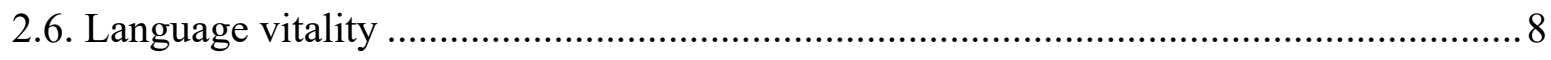

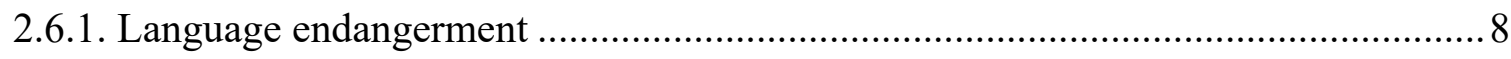

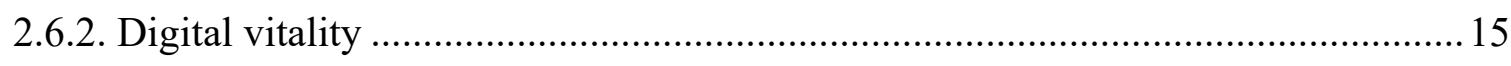

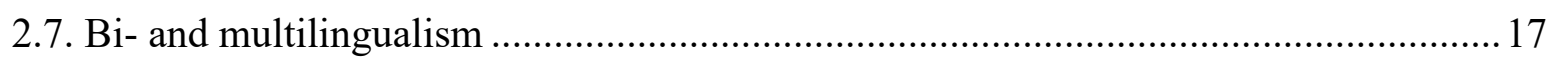

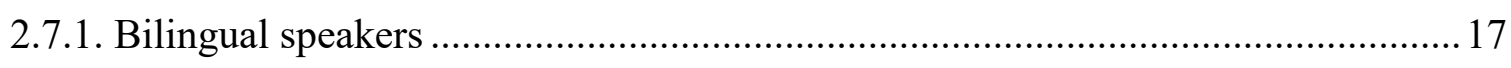

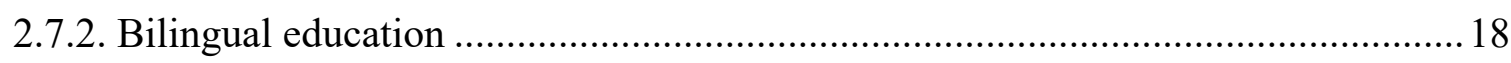

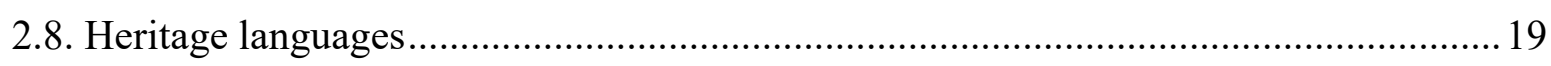

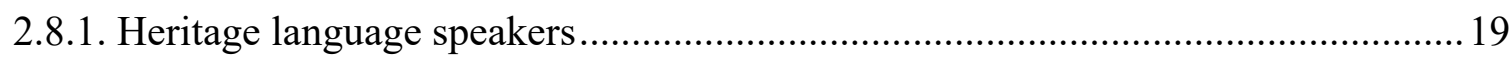

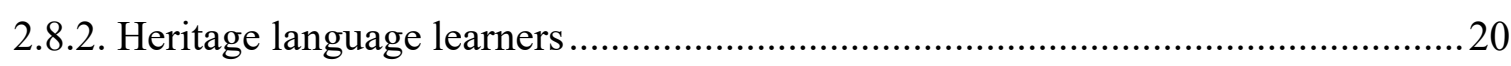

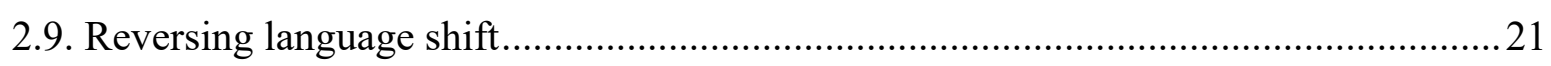

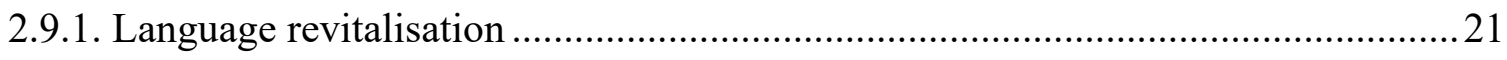

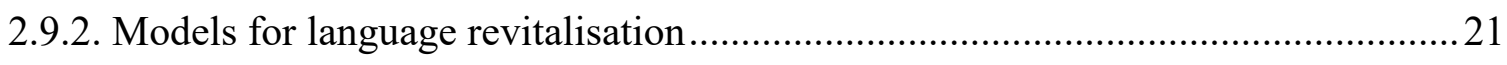

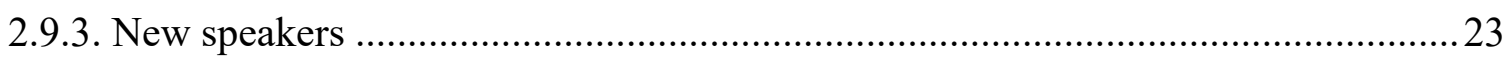

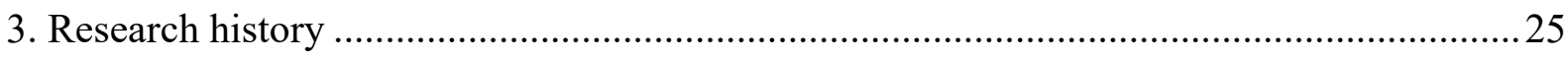

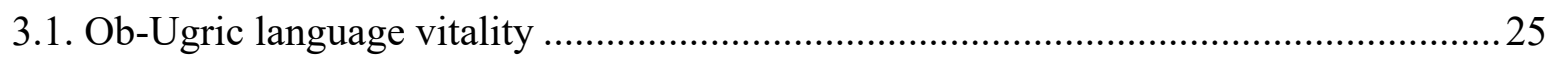

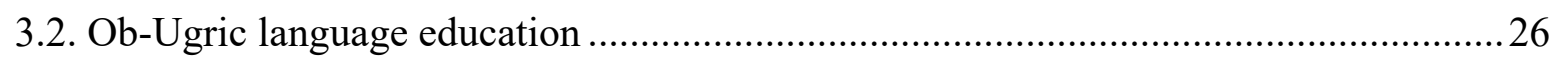

3.3. Representation of language nests in the Russian press .............................................26

3.4. Language policy concerning the indigenous peoples of the North.............................27

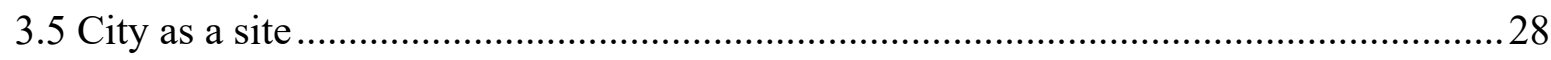

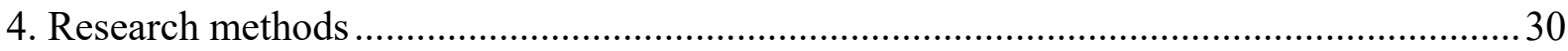




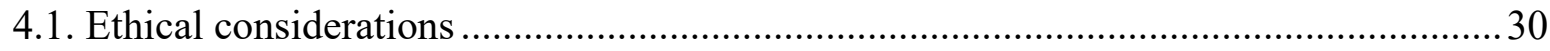

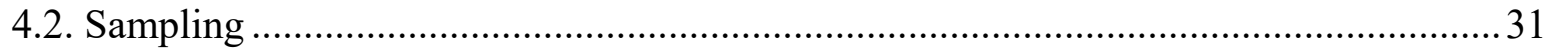

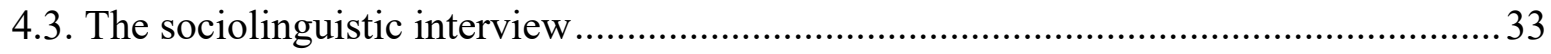

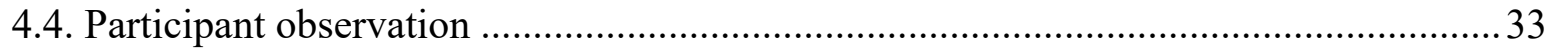

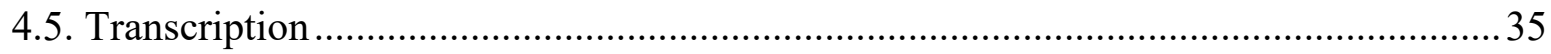

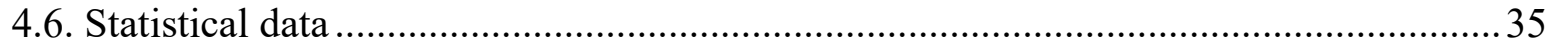

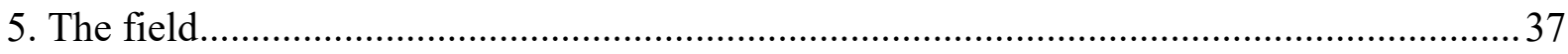

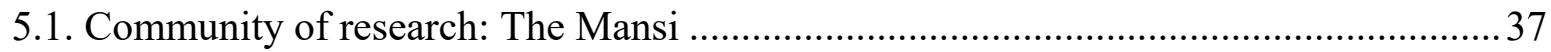

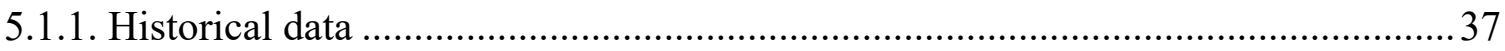

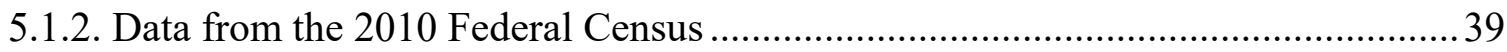

5.1.3. Data from the 2010 Federal Census regarding the Khanty-Mansi Autonomous

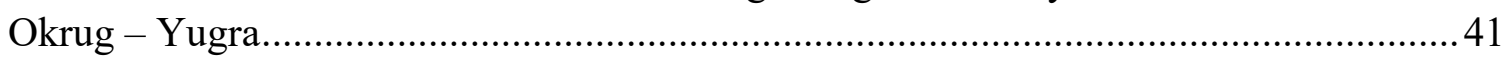

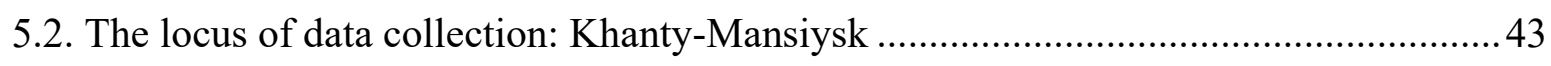

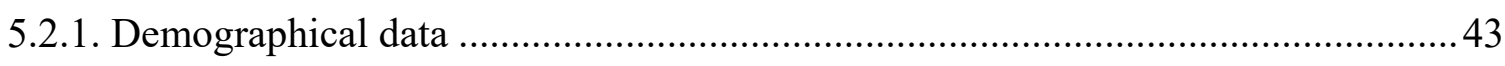

5.2.2. Institutions of Ob-Ugric relevance in Khanty-Mansiysk ..................................... 44

6. Ob-Ugric elements in the linguistic landscape of Khanty-Mansiysk ................................ 47

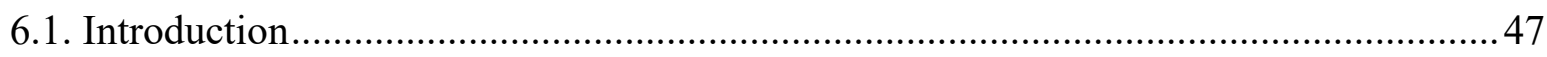

6.2. Major languages in the linguistic landscape of Khanty-Mansiysk ............................. 48

6.2.1. The Russian language in the linguistic landscape of Khanty-Mansiysk.................48

6.2.2. The English language in the linguistic landscape of Khanty-Mansiysk .................48

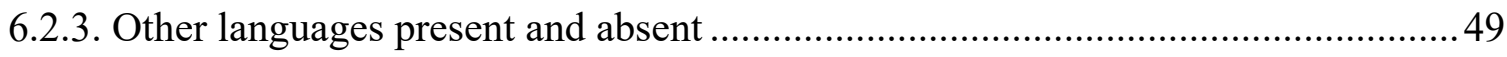

6.3. Ob-Ugric languages in the linguistic landscape of Khanty-Mansiysk.........................49

6.3.1. Ob-Ugric languages in the physical sphere ........................................................ 49

6.3.2. Visual signs and the Ob-Ugric landscape .......................................................50

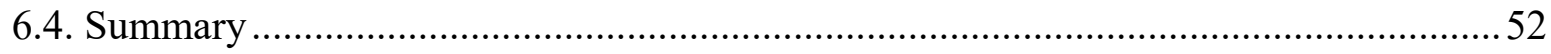

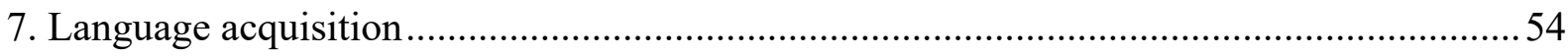

7.1. Characterising the Mansi speakers according to age groups .....................................54

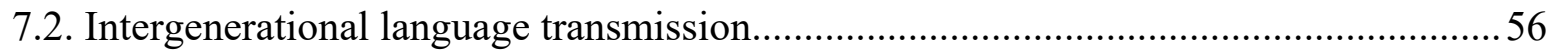

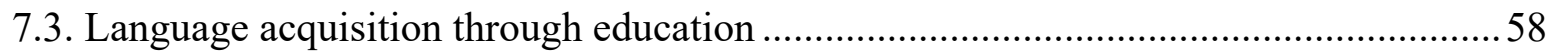

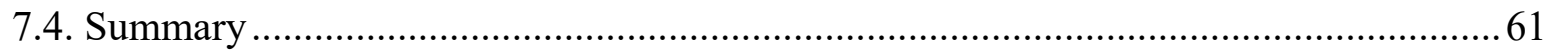

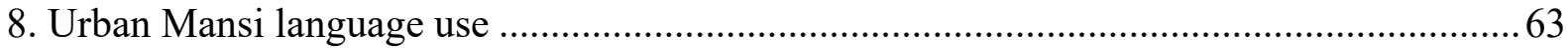

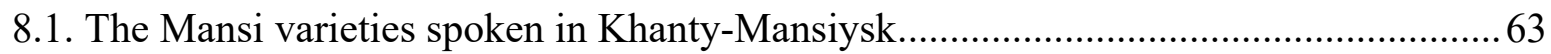

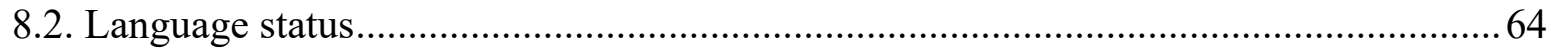

8.3. Non-linguistic conditions affecting Mansi language use ..............................................66

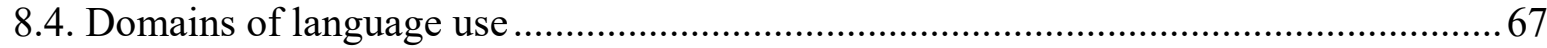




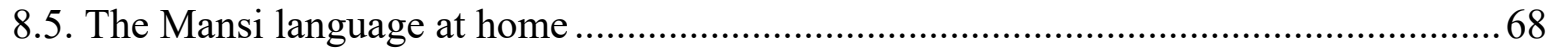

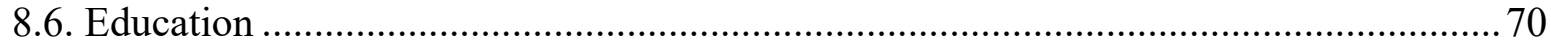

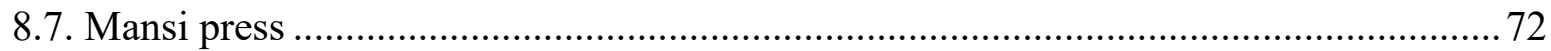

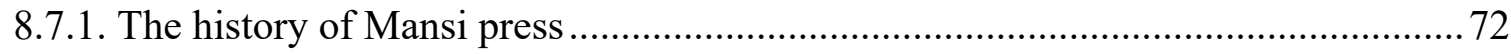

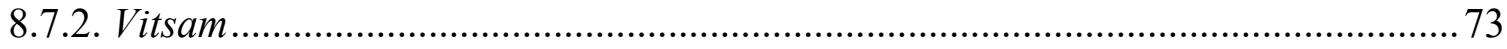

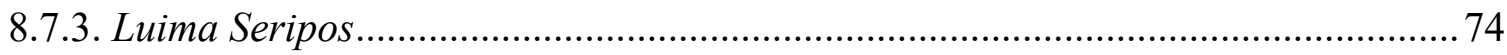

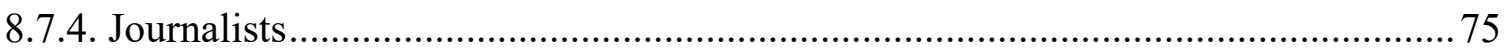

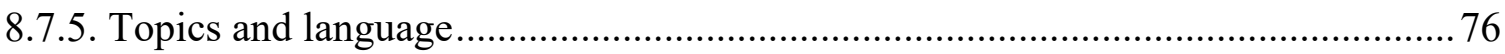

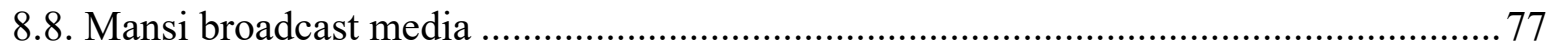

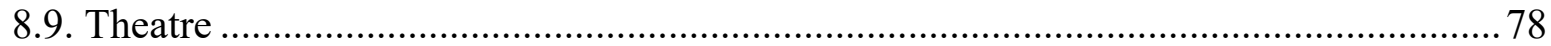

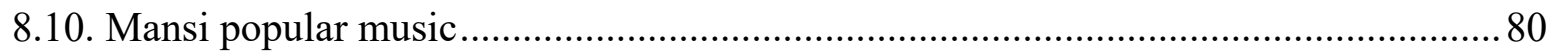

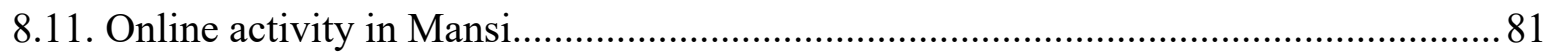

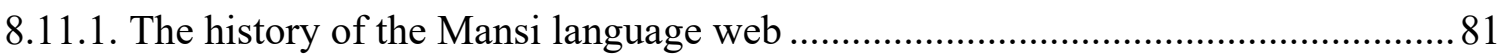

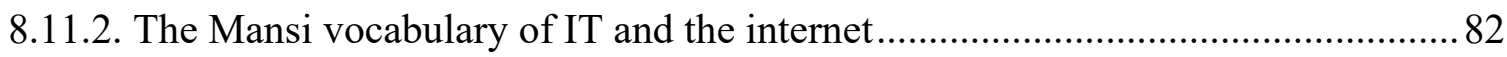

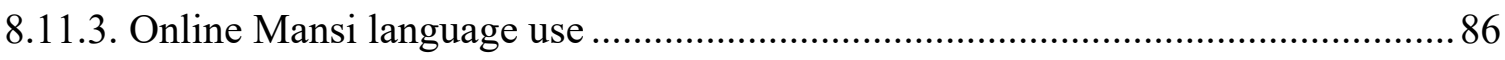

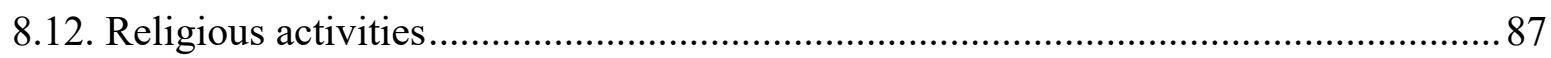

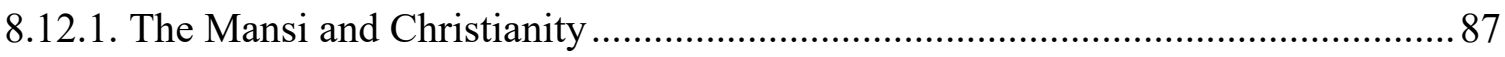

8.12.2. The classification of sacred Mansi sites .............................................................. 88

8.12.3. Mansi sacred sites in Khanty-Mansiysk and its environs ................................... 90

8.12.4. Rituals at the Torum Maa Museum........................................................................ 92

8.12.5. Attitudes towards sacred sites in Khanty-Mansiysk ........................................... 93

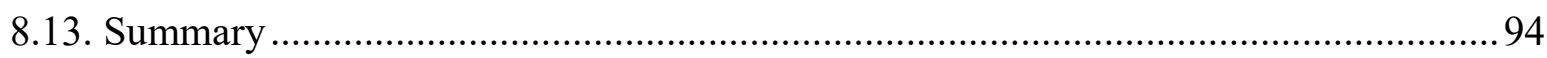

9. The role of the Mansi language in constructing ethnic identity ........................................ 96

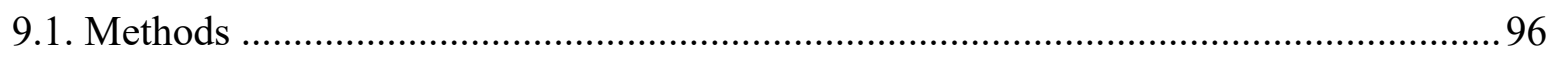

9.2. The importance of traditional markers of indigenous ethnic identity ...........................97

9.3. The assumed hierarchy of indigenous identity markers .......................................... 99

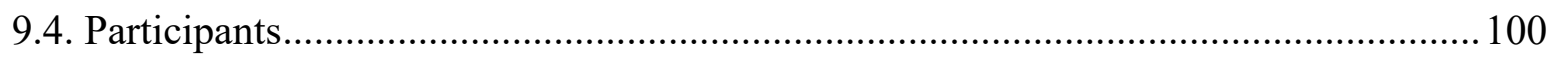

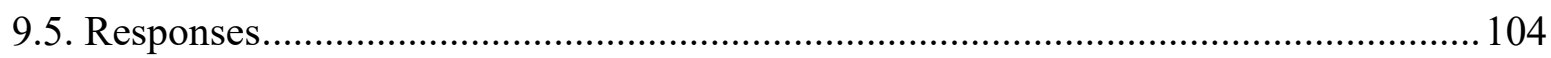

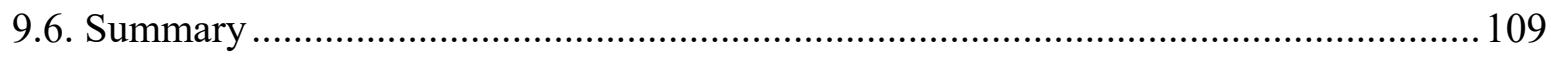

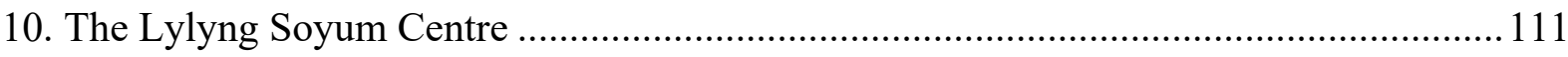

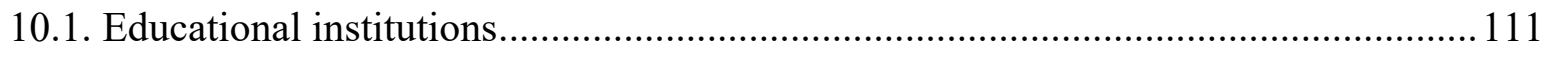

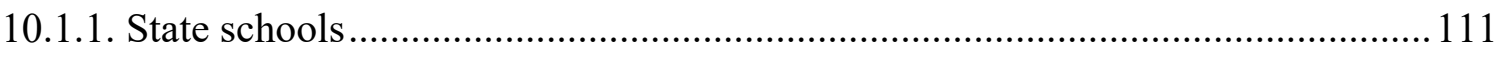

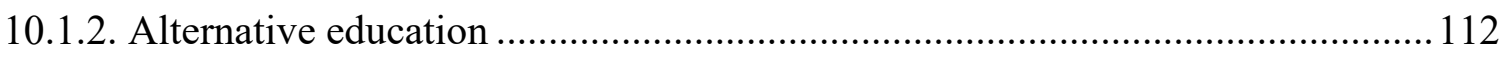

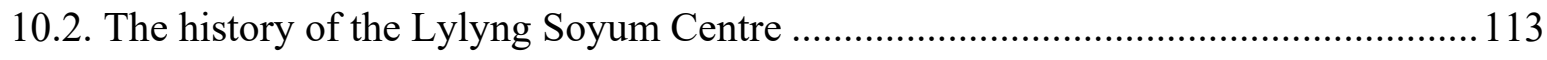

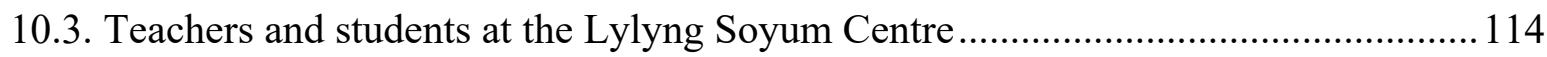




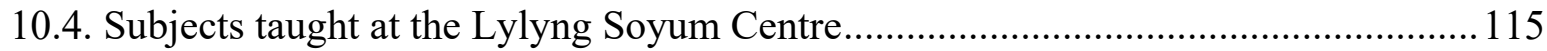

10.5. Teaching materials at the Lylyng Soyum Centre ................................................... 116

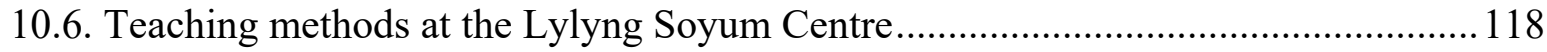

10.7. The role of the Mansi language in the curriculum of the Lylyng Soyum Centre ...... 119

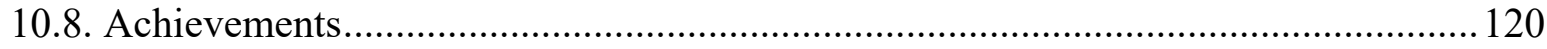

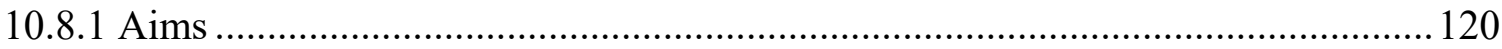

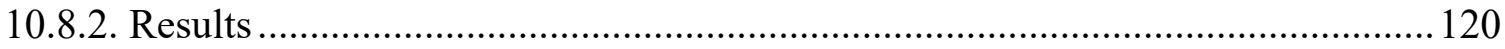

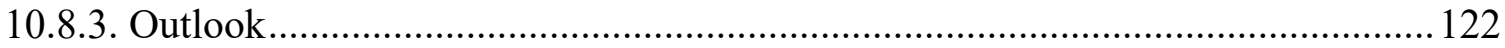

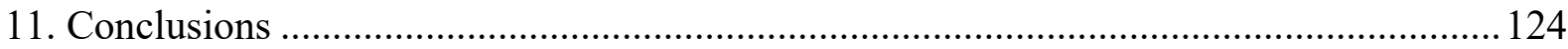

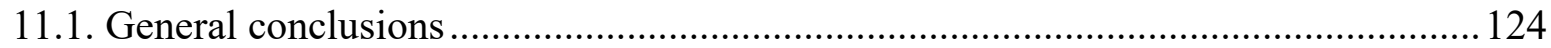

11.2. The situation of Mansi language vitality prior to the revitalisation attempts ............ 126

11.3. Mansi language revitalisation attempts in Khanty-Mansiysk ................................ 127

11.4. The effects of the Mansi language revitalisation movements on the language vitality

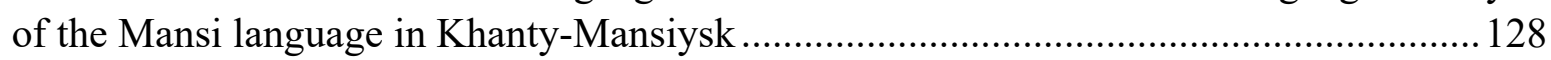

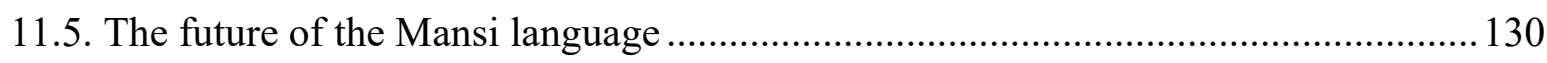

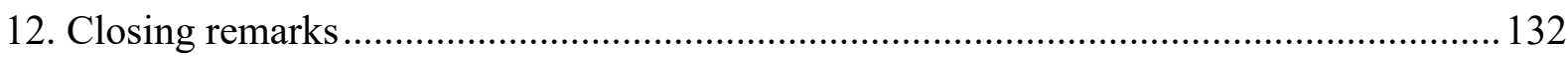

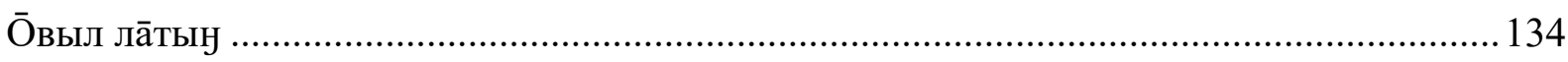

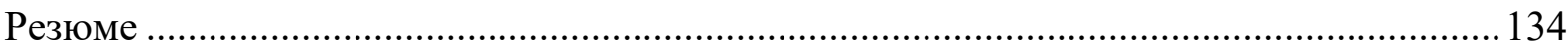

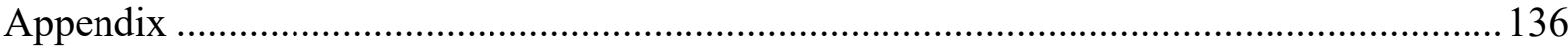

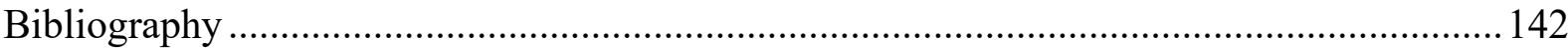




\section{Introduction}

\subsection{Research questions}

The Mansi language is an endangered indigenous minority language spoken in Western Siberia. Linguistically it belongs to the family of Uralic languages, socially it belongs among what is commonly called "numerically small indigenous peoples" in the Russian Federation.

The beginnings of bilingualism (and probable multilingualism) of the Mansi society are no doubt located in the distant past, and it would be problematic to determine the starting point of language shift, but it is certain that researchers (e.g. Munkácsi 1889a: 208, 222-224) have been complaining about the difficulty of finding native speakers due to assimilation and rapid language shift for more than a hundred years. Thus, it appears to be likely that at least a part of Mansi society became a subject of language endangerment already during the 19th century, and the process has continued ever since.

Interpreting the data of 2002 and 2010 Russian federal censuses, linguists often refer to this process taking place in the community of the Mansi (and some other smaller Finno-Ugric language) speakers as language death due to the rapidness of language shift, thus emphasising that language shift is essentially complete or in any case irreversible. In further cases, in opposition to those emphasising the inevitability of the process rather than the possible responsibility of the actors, other linguists (e.g. Sipos 2004: 17) use the term linguicide, promoted by Skutnabb-Kangas (Skutnabb-Kangas and Phillipson 1994). As a result of fieldwork carried out after the turn of the century, more thorough and precise descriptions of the process of language shift and linguistic vitality were published, using the term language shift (for Mansi, see e.g. Bíró and Sipőcz 2009). Thus, it is a well-known fact by now that at the turn of the $21^{\text {st }}$ century, similarly to essentially all cases of minority bilingualism, MansiRussian bilingualism is asymmetrical: while practically all Mansi speakers are able to speak Russian to some extent, only a handful of people were found among Russians or other ethnic groups able to speak Mansi. The most important factors resulting in Mansi-Russian bilingualism and Mansi language endangerment have been colonisation, the numerical and economic marginalisation of the Mansi, as well as the assimilation-oriented, centralised education system, and economically motivated migration in the region inhabited by Mansi.

The cultural branding strategy of the district, as a factor activating the scheme of ethnic identity, also gave advantage to the emergence of revitalisation efforts. The Khanty-Mansi 
Autonomous Okrug and Khanty-Mansiysk as its administrative and cultural centre often use the name Yugra, which refers to the indigenous Ob-Ugric peoples, as well as to ornaments and festivals originating from Ob-Ugric traditions, thus creating the district's and the city's own identity within Russia (Nagy 2016: 10-11). In order to "authentically" represent the Ob-Ugric cultural elements, the majority society needs Ob-Ugrians, including Mansis, who are considered "authentic", but defining the authentic Ob-Ugric identity is not unproblematic in urbanised conditions. While for both the legislative authorities and the scholarly community authentic representatives of the Ob-Ugric peoples often equal the followers of the traditional lifestyle, that is, those living off fishing, hunting, and reindeer herding, this subgroup makes up barely $8 \%$ of the population of the Ob-Ugric peoples (Nagy 2020:23) and is unrepresented among the Mansi living in Khanty-Mansiysk. Since in the urban environment the Mansi of Khanty-Mansiysk are deprived of their most tangible identity-marking element, the traditional way of life, particular importance in attached to other identity markers, for example the knowledge of Mansi culture, including Mansi language proficiency. Therefore, revitalisation attempts necessarily appeared earlier in the urban settings, that is, in an environment where many cultural groups interact with each other (Eriksen 1993: 329), as for the expression of ethnic differences at least the presence of two opposing, isolated ethnic groups is necessary.

In my dissertation I am seeking answers to the following questions:

(1) How is the vitality of the Mansi language in Khanty-Mansiysk prior to the emergence of revitalisation efforts and initiatives best described?

(2) What kind of revitalisation attempts has been appearing in Khanty-Mansiysk, aiming at the revitalisation of the Mansi language? Who are the initiators of these efforts? What are the goals of these initiatives, which groups constitute their target audience? To what extent have these initiatives been effective in relation to their goals?

(3) How has the situation of the vitality of the Mansi language in Khanty-Mansiysk changed as a result of the revitalisation efforts? 
Khanty-Mansiysk is an excellent site for studying the process of revitalisation among indigenous minorities living in urbanised environments, because, as the administrative, educational and cultural centre of the Khanty-Mansi Autonomous Okrug and the home of onetenth of the Mansi living in Russia, it offers an ideal opportunity for revitalisation initiatives as well as for research into the short-term results of these initiatives.

In the present dissertation after briefly introducing theoretical background (Chapter 2), research history (Chapter 3) and research methods (Chapter 4), I present a detailed description of the field (Chapter 5), the role of the Mansi language in the linguistic landscape of KhantyMansiysk (Chapter 6) and in the formation of ethnic identity by the Mansi living in KhantyMansiysk (Chapter 9). I analyse Mansi language acquisition (Chapter 7) and Mansi language use (Chapter 8), and because of its prominent role in both language acquisition and language revitalisation, I write in detail about the Lylyng Soyum Centre (Chapter 10), and its impact on the tendencies of Mansi language acquisition and language use in Khanty-Mansiysk (Chapter $11)$.

\subsection{Significance of the research questions}

The aim of my dissertation is to provide an introduction to and description of the endeavour and initiatives aimed at the revitalisation of the Mansi language in the city of KhantyMansiysk between 2003 and 2020, as well as an analysis of the institutions and other achievements created as a result of these initiatives.

According to a UNESCO report (UNESCO 2003), 50-90\% of the world's known languages are unlikely to survive the turn of the next century. Due to the limited amount of information available on the indigenous endangered languages of Siberia and the Russian Far East, sociolinguistic research into the Mansi language, especially its revitalisation attempts, as well as the study of urban language use and language vitality are of particular importance.

The impact of urbanisation on indigenous languages, the teaching or acquisition of endangered indigenous languages in urbanised conditions are relatively new research topics. This is especially true of the Uralic languages. While a large proportion of indigenous peoples speaking Uralic languages live in cities, and institutions experimenting with linguistic revitalisation are also appearing in small but rising numbers, the literature is still limited to a 
handful of studies, primarily carried out in Finland (e.g. Huss 1999, Olthuis et al. 2013, Pasanen 2015).

Linguistics, ethnography and cultural anthropology equally owe with the research of urbanisation of the indigenous people of Siberia, this debt is even more imperative, since "we may observe that by neglecting the city as a domain, not only the vast majority of Siberia's population is ignored, but also a significant portion of those belonging to indigenous minority peoples of the North is excluded from research. If we look at the Ob-Ugric peoples, the difference is even larger than the average: almost every second person is lost" (Nagy 2016: 5; my translation).

Regarding the status of the language, Mansi is an indigenous minority language, without any kind of official status. The consequences of rapid urbanisation, namely, the altered lifestyle, the multi-ethnic environment, the Russian-dominated press and media, etc. intensify the influence of factors accelerating language shift and create new opportunities to support language revitalisation attempts (cf. Horváth 2012). Although the domains of Mansi language use are becoming more numerous than before, they are still limited. Mansi is not an official language, neither at the regional nor the municipal level, and it is practically absent from official or semi-official domains such as legislation, public transport, or street signage. Mansi has no economic significance either, thus, it plays a marginal role in the business sphere or the labour market. Mansi has a small but growing importance in cultural and leisure activities, as well as on the internet, and, compared to these domains, it has a relatively strong position in education and the family. 
2. Theoretical background

In this chapter of the dissertation I discuss the theoretical framework that provides the basis for the present work, from the point of view of the various disciplines that underpin it.

\subsection{Sociolinguistics}

Sociolinguistics is a field of applied linguistics. Wardhaugh defines sociolinguistics as the discipline investigating the connection between language and society (Wardhaugh 2006: 1). According to Coulmas's more detailed description, the primary concern of sociolinguistics is to study correlations between language use and social structure. Sociolinguistics focuses on describing language use as a social phenomenon, and, where possible, it also tries to indicate causal links between language and society (Coulmas 1998: 5).

Regarding the perspective of sociolinguistic studies, micro- and macrosociolinguistics may be distinguished. Micro-sociolinguistics examines how social structure influences the way people talk, and how varieties correlate with social variables, while macro-sociolinguistics observes attitudes and attachments that explain the functional distribution of speech forms in society, as e.g. language shift, maintenance, and replacement (Coulmas 1998: 5-6). According to Trudgill, macrosociolinguistics may cover variationist linguistics, multilingualism, social dialectology, the sociology of language, that is areas involving the study of larger groups of speakers, while microsociolinguistics focuses on smaller groups of speakers and includes the sociolinguistic study of face-to-face interactions (Trudgill 2004: 1-2).

\subsection{The sociology of language}

Trudgill describes the sociology of language as a subfield of sociolinguistics which has partly social scientific goals and which investigates the relationship between sociological factors and language on a macrosociolinguistic scale, and in particular with language choice. According to his definition, the sociology of language covers the study of multilingualism, language planning, language maintenance and language shift, not drawing a very strict line between the two approaches, saying "we may, without too much distortion, observe [sociology 
of language] as an organisational principle that some work tends to be more language oriented, while other work is more society oriented" (Trudgill 2004: 4-5).

The sociology of language is often mentioned in relation to sociolinguistics, with which it is sometimes identified and sometimes contrasted. According to Janicki, if we place the sociology of language and sociolinguistics along a continuum of interest for the social aspects of language, the sociology of languages will concentrate on macro-linguistic phenomena, while sociolinguistics focusing on micro-sociological phenomena (Janicki 2004: 67).

\subsection{Linguistic anthropology}

The sociologically motivated research of languages in generally based on what is most often referred to as the Sapir-Whorf hypothesis, according to which language defines how people in various cultures perceive the world. Languages, even not actively used ones, define social groups. As a sub-discipline of anthropology, linguistic anthropology investigates how languages form social identity and group membership, and how they shape cultural beliefs and ideologies (ELDIA 2014: 23-24).

Among the disciplines in the social sciences and humanities that study communication, sociolinguistics is the closest to linguistic anthropology. Although sociolinguists traditionally favour quantitative methods and tend to work in urban environments while most linguistic anthropologists seem to prefer qualitative methods and often work in smaller scale communities, the overall goals of their research agendas appear very similar, especially since anthropologists have been turning their attention to urban contexts. Sociolinguists are also concerned with the definition of the speech community as a reference point for investigating the limits of individual variation in language use, while other foci of study, such as register, language and gender, speech acts, or discourse, have been more often shared with linguistic anthropologists (Duranti 1997: 13-14).

\subsection{Linguistic landscape}

In the past decades the investigation of the linguistic landscape has become a field of research on its own right. At an early stage studies focused on static public written signage, later the observations included textual elements on dynamic visual surfaces such as "flat screen 
displays, video walls and other dynamic visual stimuli" (Marten et al. 2012: 4) as well. The definition of linguistic landscape generally covers written elements only. The founding definition of the field by Landry and Bourhis (1997: 25), for example, identifies linguistic landscape as "visibility and salience of languages on public and commercial signs in a given territory or region", while according to Backhaus's permissively wide understanding (Backhaus 2006: 66), "any piece of written text within a spatially definable frame" qualifies for being regarded as part of the linguistic landscape.

Similarly, the approaches to interpret and analyse the collected material have changed over the years. In addition to the early studies focusing exclusively on the opposition of private and governmental language use, top-down and bottom-up language policies, sometimes complemented with quantitative research as well, the qualitative research methods, such as background interviews with those placing the sings and those regularly facing them, or the comparison of the patterns characterising oral and written language use, contribute to a deeper understanding of different linguistic phenomena (Marten et al., 2012: 3-4). The extension of the field of research as well as the research methodology is natural and understandable, since, as Hornsby and Vigers (2012: 74) also state, linguistic landscape is an important element of linguistic ecology, thus, investigating the symbolic structure of the community spaces also helps the mapping of the use of linguistic resources.

While the importance of language documentation and studying the patterns of indigenous minority language use has increased in the last decades, much less attention has been paid to observing the appearance of indigenous minority languages in linguistic landscapes. The observation of the minority languages of the Russian Federation as appearing in the linguistic landscape would be extremely urgent and important in post-Soviet cities. The change from the Soviet establishment to consumer culture altered the linguistic landscape of cities and changed the role of cities as well, turning communal spaces into the domains of advertisement and also into the sites of new identity constructions (Muth 2016: 19). Nevertheless, papers on post-Soviet urban linguistic landscape almost exclusively deal with Russian only. Detailed information on the role of Mansi in the linguistic landscape of KhantyMansiysk is to be found in Chapter 6 below.

\subsection{Language status}


The terms 'official language', 'national language' and 'state language' are sometimes used synonymously. The practical role of an official language is to function as the working language of public authorities and institutions; while a national language is associated with a nation, and although it is regarded as a language of a political, social and cultural entity, it does not necessarily function as an official language. In countries with a nation state tradition, the official language is often associated with the state, usually bears the designation 'state language', and serves both practical and symbolic functions. Scholars in Russia typically differentiate between the terms 'official language' (официальный язык) and 'state language' (государственный язык), and since the USSR and post-Soviet Russia were established not as 'nation-states' but as multinational states, the term 'national language' (национальныц язык) was employed for the languages of the peoples, that is, of nations, nationalities or ethnic groups (Zamyatin 2014: 17-18).

The term 'minority language' is often used to refer to a language spoken by a minority community of a country, even if the language is given official status. In post-Soviet Russia, on the other hand, speakers of non-dominant languages tend to have separate ethnic and national identities, as the result of which ethnic activists typically reject to label their language with the term 'minority language' (язык меньиинств), and prefer the term 'national language' (Zamyatin 2014: 18-19).

Mansi is most often framed in the language status discourse as the language of an indigenous small-numbered nation of the North, as well as a Finno-Ugric language, while reflection on the actual status of the language is missing.

\subsection{Language vitality}

\subsubsection{Language endangerment}

According to the well-known prognosis, by the turn of this century a large proportion of the existing languages are going to disappear. According to Austin and Sallabank, this means more than a half of the 7,000 languages existing now (Austin and 1992

: 1), or about 50-90\% of 6-7,000 languages, according to Grenoble (2011: 26). Although the rapid decrease in the number of languages has been happening since at least the middle of the $20^{\text {th }}$ century, language endangerment became a leading topic in sociolinguistics (and linguistics in general) only in 1992, after a special issue of the journal Language (Hale et al. 
1992) called for a concerted effort to record the remaining speakers, and to create linguistic archives for future reference.

The endangerment of a language may originate from a natural catastrophe, war or genocide, overt repression or assimilation, and dominance of cultural, political or economic nature (Austin and Sallabank 2011:5). Language endangerment causes great loss for linguistics, carrying with it an invaluable segment of cultural heritage. The degree of a language's endangerment may be defined according to different scales. Enumerating the most prominent and relevant scales in chronological order, the first such scale is Krauss' (1997) system, classifying the endangered languages according to the number and age of the speakers.

\begin{tabular}{|l|l|}
\hline LEVEL & DESCRIPTION \\
\hline a & $\begin{array}{l}\text { the language is spoken by all generations, including all, or nearly all, of the } \\
\text { children }\end{array}$ \\
\hline a- & the language is learned by all or most children \\
\hline b & $\begin{array}{l}\text { the language is spoken by all adults, parental age and up, but learned by few or no } \\
\text { children }\end{array}$ \\
\hline b- & the language is spoken by adults in their thirties and older but not by younger parents \\
\hline c & the language is spoken only by middle-aged adults and older, in their forties and up \\
\hline c- & all speakers in their fifties and older \\
\hline -d & all speakers in their sixties and older \\
\hline d & all speakers in their seventies and older \\
\hline d- & all speakers in their seventies and older, and fewer than 10 speakers \\
\hline e & extinct, no speakers \\
\hline
\end{tabular}

Table 1. Krauss' scale for measuring language endangerment

The most fundamental model to describe language endangerment has been Fishman's Graded Intergenerational Disruption Scale (GIDS), according to which the higher the GIDS level of a language is, the lower the ratings are regarding intergenerational continuity and maintenance perspectives of a language community (Fishman 1991a: 87-109). 


\begin{tabular}{|l|l|}
\hline LEVEL & DESCRIPTION \\
\hline Stage 1 & $\begin{array}{l}\text { Some use of Xish in higher level educational, occupational, governmental and media } \\
\text { efforts }\end{array}$ \\
\hline Stage 2 & $\begin{array}{l}\text { Xish in lower governmental services and mass media but not in the higher spheres of } \\
\text { either }\end{array}$ \\
\hline Stage 3 & $\begin{array}{l}\text { use of Xish in the lower work sphere (outside of the Xish neighborhood/community) } \\
\text { involving interaction between Xmen and Ymen }\end{array}$ \\
\hline Stage 4a & $\begin{array}{l}\text { Xish in lower education that meets the requirements of compulsory education laws: } \\
\text { Schools that are under Xish control and that can be attended in lieu of compulsory } \\
\text { education }\end{array}$ \\
\hline Stage 4b & $\begin{array}{l}\text { Xish in lower education that meets the requirements of compulsory education laws: } \\
\text { Schools for Xish pupils but under Yish control }\end{array}$ \\
\hline Stage 5 & $\begin{array}{l}\text { Xish literacy in home, school and community, but without taking on extra-communal } \\
\text { reinforcement of such literacy } \\
\text { the attainment of intergenerational informal oralcy and its demographic concentration } \\
\text { and institutional reinforcement }\end{array}$ \\
\hline Stage 6 & $\begin{array}{l}\text { most users of Xish are a socially integrated and ethnolinguistically active population but } \\
\text { they are beyond child-bearing age }\end{array}$ \\
\hline Stage 7 & $\begin{array}{l}\text { most vestigial users of Xish are socially isolated old folks and Xish needs to be re- } \\
\text { assembled from their mouths and memories }\end{array}$ \\
\hline Stage 8
\end{tabular}

Table 2. Summary of Fishman's GIDS

While the GIDS, at its introduction, provided new framework of the dynamics of language shift, several imperfections have become apparent since then. Fishman identified intergenerational transmission of a language as the single most important factor in language shift and paid limited attention to other domains or the interaction of domains.

The UNESCO framework (2003) establishes six categories in a scale of language vitality. For the purpose of describing the status of a language, the framework provides a set of 9 factors that can be observed to determine the category a language belongs to.

1. Intergenerational language transmission

2. Absolute number of speakers

3. Proportion of speakers within the total population 
4. Shifts in domains of language use

5. Response to new domains and media

6. Availability of materials for language education and literacy

7. Governmental and institutional language attitudes and policies including official status and use

8. Community members' attitudes toward their own language

9. Amount and quality of documentation

Each factor is accompanied by a graded scale, value ' 5 ' is assigned to the optimal situation and value ' 0 ', to the direst one (UNESCO 2003).

\begin{tabular}{|l|l|}
\hline DEGREE OF ENDANGERMENT & INTERGENERATIONAL LANGUAGE TRANSMISSION \\
\hline Safe & $\begin{array}{l}\text { The language is spoken by all generations; intergenerational } \\
\text { transmission is uninterrupted }\end{array}$ \\
\hline Vulnerable & $\begin{array}{l}\text { Most children speak the language, but it may be restricted to certain } \\
\text { domains (e.g., home) }\end{array}$ \\
\hline Definitely endangered & Children no longer learn the language as mother tongue in the home \\
\hline Severely endangered & $\begin{array}{l}\text { The language is spoken by grandparents and older generations; } \\
\text { while the parent generation may understand it, they do not speak it } \\
\text { to children or among themselves }\end{array}$ \\
\hline Critically endangered & $\begin{array}{l}\text { The youngest speakers are grandparents and older, and they speak } \\
\text { the language partially and infrequently }\end{array}$ \\
\hline Extinct & There are no speakers left \\
\hline
\end{tabular}

Table 3. The UNESCO framework of language endangerment

The UNESCO framework provides the richer set of categories the more endangered the language in question is, while it does not differentiate the status of languages which are above Level 6 on the GIDS scale. This framework has not been changed since 2003, while during the evaluation of the result for their questionnaire disseminated through various networks in 20062009, UNESCO researchers introduced a reliability index in order to determine the reliability 
of the data provided by linguists. The respondents were to choose the scores to categorise their replies:

3 Evidence from field work and direct observation

2 Evidence from other reliable sources

1 Very little evidence; a 'best guess'

0 No data available (UNESCO 2011).

Ethnologue categorised language vitality in terms of a five-point scale which is focused on the number of first-language speakers rather than on other factors connected to language use (Lewis and Simon 2010: 108). Though this categorisation is called a scale in all over the literature of language vitality and uses simple and clear criteria, it still does not lack inconsistency, since many languages falling into the categories of 'living' or 'second language only' languages may as well as be put into the category of nearly extinct languages for having fewer than 50 first or second language speakers.

\begin{tabular}{|l|l|}
\hline CATEGORY & DESCRIPTION \\
\hline Living & Significant population of first-language speakers \\
\hline Second language only & $\begin{array}{l}\text { Used as second language only. No first-language users, but may include } \\
\text { emerging users }\end{array}$ \\
\hline Nearly extinct & $\begin{array}{l}\text { Fewer than 50 speakers or a very small and decreasing fraction of an } \\
\text { ethnic population }\end{array}$ \\
\hline Dormant & $\begin{array}{l}\text { No known remaining speakers, but a population links its ethnic identity } \\
\text { to the language }\end{array}$ \\
\hline Extinct & $\begin{array}{l}\text { No remaining speakers and no population links its ethnic identity to the } \\
\text { language }\end{array}$ \\
\hline
\end{tabular}

Table 4. The Ethnologue's scale for measuring language endangerment 
Enumerating the long list of insufficiencies found in Ethnologue's categorisation system, Lewis and Simon introduced their updated version of Fishman's GIDS, the Expanded Graded Intergenerational Disruption Scale (EGIDS). Each numbered level is accompanied with a short one- or two-word label that identifies the main functional category of that level, and the table also refers to the corresponding UNESCO endangerment category. Lewis and Simon aim for the EGIDS to be applied to all languages of the world (Lewis and Simons 2010).

\begin{tabular}{|c|c|c|c|}
\hline LEVEL & LABEL & DESCRIPTION & UNESCO \\
\hline 0 & International & $\begin{array}{l}\text { The language is used internationally for a broad } \\
\text { range of functions. }\end{array}$ & Safe \\
\hline 1 & National & $\begin{array}{l}\text { The language is used in education, work, mass } \\
\text { media, government at the nationwide level. }\end{array}$ & Safe \\
\hline 2 & Regional & $\begin{array}{l}\text { The language is used for local and regional mass } \\
\text { media and governmental services. }\end{array}$ & Safe \\
\hline 3 & Trade & $\begin{array}{l}\text { The language is used for local and regional work by } \\
\text { both insiders and outsiders. }\end{array}$ & Safe \\
\hline 4 & Educational & $\begin{array}{l}\text { Literacy in the language is being transmitted } \\
\text { through a system of public education. }\end{array}$ & Safe \\
\hline 5 & Written & $\begin{array}{l}\text { The language is used orally by all generations and } \\
\text { is effectively used in written form in parts of the } \\
\text { community. }\end{array}$ & Safe \\
\hline $6 a$ & Vigorous & $\begin{array}{l}\text { The language is used orally by all generations and } \\
\text { is being learned by children as their first language. }\end{array}$ & Safe \\
\hline $6 b$ & Threatened & $\begin{array}{l}\text { The language is used orally by all generations but } \\
\text { only some of the child-bearing generation are } \\
\text { transmitting it to their children. }\end{array}$ & Vulnerable \\
\hline 7 & Shifting & $\begin{array}{l}\text { The child-bearing generation knows the language } \\
\text { well enough to use it among themselves but none } \\
\text { are transmitting it to their children }\end{array}$ & $\begin{array}{l}\text { Definitely } \\
\text { endangered }\end{array}$ \\
\hline $8 \mathrm{a}$ & Moribund & $\begin{array}{l}\text { The only remaining active speakers of the language } \\
\text { are members of the grandparent generation. }\end{array}$ & $\begin{array}{l}\text { Severely } \\
\text { endangered }\end{array}$ \\
\hline $8 b$ & Nearly extinct & $\begin{array}{l}\text { The only remaining speakers of the language are } \\
\text { members of the grandparent generation or older } \\
\text { who have little opportunity to use the language. }\end{array}$ & $\begin{array}{l}\text { Critically } \\
\text { endangered }\end{array}$ \\
\hline 9 & Dormant & $\begin{array}{l}\text { The language serves as a reminder of heritage } \\
\text { identity for an ethnic community. No one has more } \\
\text { than symbolic proficiency. }\end{array}$ & Extinct \\
\hline
\end{tabular}




\begin{tabular}{|l|l|l|l|}
\hline 10 & Extinct & $\begin{array}{l}\text { No one retains a sense of ethnic identity associated } \\
\text { with the language, even for symbolic purposes. }\end{array}$ & Extinct \\
\hline
\end{tabular}

Table 5. Summary of Lewis and Simon 's EGIDS

A possibly less known but more complex and, thus, more accurate model of describing language endangerment was created under the European Language Diversity for All (ELDIA) project. The main empirical tool it produced, the European Language Vitality Barometer (EuLaViBar) presents the results for languages observed on the scale from 0 to 4 , with respect to four focus areas: capacity, opportunity, desire, and language products. According to the explanation provided by the creators of the EuLaViBar, capacity refers to a person's confidence to use a specific language, or the language skills as reported by the respondents themselves; opportunity refers to the existing institutional arrangements in e.g. legislation, education etc, that allow for support or inhibit the use of languages; and desire refers to the willingness or preparedness of people to use a certain language (ELDIA 2014: 14-16).

The ELDIA project used a survey questionnaire for the speakers or heritage language speakers of European minority languages, divided into thematic sections:

A. biographical section: age, birth place, education, and profession;

B. 21 questions about language acquisition and learning, language use in the family and at school, and three questions about attitudes towards using the minority language with children;

C. the respondent's self-assessed language skills in maximally seven languages on a five-point scale in four dimensions (understanding, speaking, reading, and writing);

D. the respondent's self-assessed language use in twelve domains (home, relatives, work, friends, shop, and public authorities etc.) in maximally four languages;

E. 27 questions about the respondents' attitudes towards various languages and their impressions of three languages - the minority language, the majority language, and English; 
F. two questions about the revitalisation of the minority language and its use in fifteen different public domains (e.g. the Parliament, police stations, tax offices, hospitals, radio, and TV);

G. two long questions about the respondents' consumption of diverse cultural products (theatre and concerts) and media (newspapers, books, TV; Internet, e-mail, text messages, social media etc.) as well as their active use of each language in consuming these cultural products (for instance, keeping a diary, singing songs or writing poetry) (ELDIA 2014: 32-33).

The EuLaViBar distinguishes itself from the other tools in being based on a large-scale survey and in illustrating the degree of language maintenance with a barometer based on the survey results.

According to the UNESCO categorisation, the Mansi language is definitely endangered, and according to the EDIGS classification it is located between stages 7 and $8 \mathrm{a}$. The calculation of the result of the EuLAViBar investigation would be impossible on the basis of the existing data, but we can expect great differences to be observed between desire, opportunity and capacity. Detailed description of urban language acquisition and language use is to be found in Chapters 7 and 8.

\subsubsection{Digital vitality}

The increasingly multilingual character of the internet has become the most notable internal change since its beginnings as an overwhelmingly English medium. English lost its dominance in 2001 , when it was represented by $45 \%$ of the online users. This has been the most notable development within the medium since the 1990s (Crystal 2011: 78). Kornai considers digital ascent a relatively new phenomenon as well, especially on the hundred-year timescale common in studies of language death. Digital communication was not an important domain of language until the electronic document creation became widespread in the $1970 \mathrm{~s}$, the internet and email in the 1980s, the web and blogging in the 1990s, online encyclopaedias created as open collaboration projects (first and foremost Wikipedia) in the 2000s (Kornai 2013: 2).

The relationship between endangered languages and digital media is multidimensional. Digital media does not only serve as an easily accessible domain of language use, providing 
speakers and learners new chances to learn or to use endangered languages, but as a technological tool it also offers the endangered languages new opportunities for the production and consumption of media as well as technical support for language archiving. From the perspective of language vitality and language prestige, online content wholly or partly in an endangered language may inspire the speakers and the learners of the given language to use or to study it. Besides written communication skills, online activities, such as e.g. telecommunication applications or online multiplayer games, may encourage users to use and maintain their oral skills as well (Moriarty 2011: 453-456). Thus online language use may be crucially important for heritage language users (see e.g. Fenyvesi 2014).

The Digital Language Diversity Project (Ceberio et al. 2018) establishes six categories in a scale of digital language vitality (Table 6).

\begin{tabular}{|c|c|}
\hline CATEGORY & DESCRIPTION \\
\hline Pre-digital & $\begin{array}{l}\text { The language is not present in (online) digital media, and it lacks most basic } \\
\text { preconditions for digital use. It has no technological support; the infrastructure for } \\
\text { connectivity is limited or too expensive for the average person, therefore, the } \\
\text { language cannot expand on the Internet; people's digital competence is non-existent } \\
\text { or very low. }\end{array}$ \\
\hline Dormant & $\begin{array}{l}\text { The language is not present on the Internet although some of the main pre-conditions } \\
\text { for digital usage are in place: e.g. connectivity is ensured, there is some degree of } \\
\text { Internet penetration, and most language speakers are at least basically digitally } \\
\text { literate. However, there is no technological support for the use of the language (e.g. } \\
\text { there is no keyboard support for writing the language, no t9, auto-correction, etc.), } \\
\text { especially online. Therefore, although speakers are in principle capable of using the } \\
\text { language digitally, in practice they do not do so. }\end{array}$ \\
\hline Emergent & $\begin{array}{l}\text { The language begins to be used digitally. Internet penetration is good, speakers are } \\
\text { digitally literate. Overall, however the language enjoys limited technological support } \\
\text { (e.g. such as fonts and keyboards), perhaps a few (digital) language resources (such } \\
\text { as e-dictionaries and text collections) might be available. Texting and messaging as } \\
\text { well as social media start to be used in the language, albeit not yet extensively. } \\
\text { Wikipedia, if present, is small. }\end{array}$ \\
\hline Developing & $\begin{array}{l}\text { The language is visible on the Internet and is used in communication and social } \\
\text { media, although frequency may still be occasional. Some digital media and services } \\
\text { may be available, as well as a Wikipedia; basic (electronic) language resources exist, } \\
\text { and there might be evidence of more advanced ones. At least one among the social } \\
\text { media and the operating systems used by the speakers' community might be localised. } \\
\text { An online machine translation service or tool might be available, for one language } \\
\text { pair at least. }\end{array}$ \\
\hline Vital & $\begin{array}{l}\text { The language is highly present on the Internet and is used regularly for e- } \\
\text { communication and in social media, some of which may have a localised interface. } \\
\text { There is considerable variety of digital media available. Language resources are } \\
\text { widely available. Wikipedia projects are big and actively used/participated. The } \\
\text { language can be used in all digital domains. Most used operating systems and general }\end{array}$ \\
\hline
\end{tabular}




\begin{tabular}{|l|l|}
\hline & $\begin{array}{l}\text { purpose software are localised in the language. There is evidence of machine } \\
\text { translation tools/services. }\end{array}$ \\
\hline Thriving & $\begin{array}{l}\text { The language is pervasive on the Internet and is used extensively and without any } \\
\text { technological barriers in all current digital domains, from communicative to } \\
\text { transactional ones. The latest technology is available. }\end{array}$ \\
\hline
\end{tabular}

Table 6. : The DLDP Digital Language Vitality Scale for measuring digital vitality

The presence of endangered languages in popular culture domains, especially in modern popular music, tends to have a positive impact on the prestige of the language among speakers, especially among younger ones. The globally popular music genres, in the case of endangered languages, usually starting with hip-hop and reggae, can become more localised through the use of traditional instruments and local languages, elevating the prestige of the endangered language, and, at the same time, also serving as an intermediate step between traditional ethic identity and newly created ways of language use and expressions of identity (Moriarty 2011: 456-457). Widely available technology directs the creation and consumption of pop-culture to the online sphere, intensifying its spread and impact.

The digital vitality of the Mansi language is close to non-existent. Although some of the speakers with native Mansi competence have digital skills as well, Mansi speakers are absent from the majority of existing digital platforms, with the exception of the social media sites. More detailed information on online Mansi language use is to be found in section 8.11 below.

\subsection{Bi- and multilingualism}

\subsubsection{Bilingual speakers}

Endangered language communities are, by definition, multilingual speech communities, because language endangerment is caused by language shift, a more widely used and more powerful language gaining dominance over the domains of language use, while the endangered language decreasing to the point of not being heard (Grinevald and Bert 2011: 58). The speakers of endangered languages are mostly bilingual, almost always speaking the mainstream language as well (Fishman 2001a: 5).

A basic typology includes seven types of speakers considered to be typical of situations of language endangerment. The first three major types, namely, fluent speakers, semi-speakers 
and terminal speakers, are relatively well known. The category of rememberers, that is, of speakers who were forced to hide their proficiency but who may regain the possibility for active use, is less well defined but widely acknowledged. Less recognised are the categories of ghost speakers, that is, of those who against all the evidence deny to have proficiency in the endangered language, and of new speakers, that is, language learners appearing as the result of revitalisation programmes (Grinevald and Bert 2011: 49-52).

\subsubsection{Bilingual education}

Bilingual education refers to the use of two or more languages in instruction. The use of a language as a medium of instruction in state-funded school systems guarantees recognition and status to the language and its speakers within the minority and majority community as well, thus having an impact on language use and language prestige (Cummins 2009: 19). Bilingual education is different from traditional language education programs that teach a second or a foreign language, since they teach the language as a subject, while bilingual education uses the given language as a medium of instruction ${ }^{1}$ (García 2008: 6).

Bilingual education is often supported by the government, although generally not as a tool for revitalising minority languages, but rather for using them as tools of transition. Still, if bilingual education becomes available in an endangered language, the speakers of the language in question and often other minority populations as well see it as an opportunity to elevate language prestige and facilitate language survival. Even in cases when the use of minority languages is discouraged, forbidden, punished, or ridiculed, the mere presence of minority languages in the curriculum helps children to redevelop positive attitudes toward the minority language. Bilingual education in minority languages also provides opportunities for the development of writing systems, new vocabulary, and new written genres (Hinton 2011: 296).

Educators of bilingual programs implemented to serve the interests of dominant groups often argue that linguistic minority students need to become fluent and literate in the dominant language in order to succeed, which makes maximum exposure to the dominant language necessary. This argumentation makes bilingual education involving instruction partly in a

\footnotetext{
${ }^{1}$ Although in García's (2008: 6) word "bilingual education programs teach content through an additional language other than the children's home language", in fact, bilingual education may just as easily use the child's home language as one of the languages of instruction. According to Hinton (2011:296), "bilingual education is a model where academic subjects are taught in both a child's native language and in the dominant language of the school system", which is often, but not necessarily true. Both languages of instruction may be different from the child's native language.
} 
minority language dismissed on the grounds that it obstructs children's opportunity to master the majority language. Often even parents of minority group children or the children themselves support this explanation (Cummins 2009: 19-20). A detailed description of the Mansi language education is presented in sections 7.2 and 8.6 below.

\subsection{Heritage languages}

The concept of heritage language seems to appear in Bloomsfield's 1927 Literate and illiterate speech for the first time (Polinsky 2018: 2), while the term heritage language was coined in Canada in the early 1970s, and it has been gaining significance in United States since the 1990s (Hornberger and Wang 2008: 3).

In Canada, the term 'heritage language' refers to the non-official (other than English and French) and non-aboriginal languages (Duff 2008: 72), whereas in the United States it can mean a language other than English, spoken by immigrants and their children (Valdés 2001), or minority languages in general (Cummins 2005: 586), including colonial, immigrant and aboriginal languages as well. According to Montrul, heritage language may refer to any ancestral language, regardless of the fact whether it is spoken in the community or not (Montrul 2016: 14-15).

I regard the Mansi language as a heritage language, for those Mansi individuals or individuals of Mansi parentage living in Mansi communities where the Mansi language is still used, who are unable to participate in the Mansi language use, as well as for those Mansi or individuals of Mansi parentage, who have been living outside Mansi communities and would not be able to participate in Mansi language use if they were exposed to it.

\subsubsection{Heritage language speakers}

The term 'heritage speaker' was originally developed in the context of the Ontario Heritage Languages program in 1977, then it began to be used more broadly in the 1990s (Cummins 2005: 585). Heritage speakers can briefly be defined as unbalanced bilinguals whose heritage language is their first language, while according to Polinsky's more detailed description, they are simultaneous or successive bilinguals whose weaker language corresponds 
to the minority language and whose stronger language is the dominant language of their society (Polinsky 2018: 9).

In the narrow sense, the definition includes only those bilinguals who were exposed to the minority language from birth (Polinsky and Kagan 2007), while the more lenient interpretation also covers people of heritage background, who had no heritage language environment as a child but become interested in learning or revitalising their heritage language later (Fishman 2001).

Heritage language speakers may have both productive and receptive skills in the heritage language, or only receptive skills. Those heritage language speakers who appear to have low to none productive skills with the ability to comprehend the heritage language are called receptive bilinguals or overhearers (Montrul 2016: 44).

I regard as Mansi heritage speakers those individuals who have Mansi as their heritage language, and who have been exposed to Mansi language use during their life, and have some receptive skills.

\subsubsection{Heritage language learners}

The first volume on heritage language learners, Webb and Miller (2000), appeared in 2000 (Hornberger and Wang 2008: 3). Valdés defines heritage language learners as individuals with connection to minority languages not taught at school, or people bilingual in the majority language and a heritage language, attending language classes (Valdés, 2001: 37-38).

According to Montrul, those who have not been exposed to the heritage language during their childhood may not be called heritage language speakers, and even if they become heritage language learners in their adult life, they would show no difference to second language learners, as they possess no previous knowledge of the heritage language (Montrul 2016: 20). DołowyRybińska, on the other hand, argues that heritage language learners would have more emotional attachment to the heritage language than second language learners to the foreign language (Dołowy-Rybińska 2020: 31).

Heritage language education covers the different kinds of education targeted at heritage language learners, including indigenous language revitalisation attempts as well (Hornberger and Wang 2008: 11). 
I regard as Mansi heritage language learners those Mansi heritage language speakers who participate in any kind of Mansi language education or self-education during their life, partly or entirely as a result of their own decision.

\subsection{Reversing language shift}

\subsubsection{Language revitalisation}

The idea that on-going language shift can be prevented or reversed was first raised by Fishman and became more widely known with his monograph Reversing Language Shift in 1991 (ELDIA 2014: 27). Since then, a wide variety of strategies for revitalising endangered languages has been developed (e.g. Fishman 2001a, Grenoble and Whaley 2006, Olthuis et al. 2013, Pasanen 2015). Revitalisation means bringing a language back to renewed life (Ostler 2011: 331).

The aim of revitalisation is to act positively on the process of transmission of a language. (Ostler 2011: 332) The goal of revitalisation is to increase the relative number of speakers of a language and to extend the domains of language use. It may be contrasted to language maintenance, which aims to protect current levels and domains of use. Revitalisation almost always requires the changing of language attitudes, often not only in the minority community, but in the majority society as well, while maintenance seeks to protect against the imposition of outside attitudes (Grenoble and Whaley 2006: 13).

The two main strategies in language policy to revitalise endangered languages according to Sallabank are the expansion of domains of language use and the phatic route. Domain expansion relies on schooling, necessarily involves standardisation and modernisation, but rarely reproduces intergenerational transmission in the family. The phatic route promotes the use of the endangered language in the home and encourages users to endorse the link between language and identity (Sallabank 2011: 289). The process and effects of Mansi revitalisation attempts are evaluated in Chapter 11.

\subsubsection{Models for language revitalisation}

Establishing education in a threatened language proves to be extremely difficult if the language in question is not acquired as ethnic mother tongue by children, and if the language is 
not used outside school or after schooling, that is, when the revitalisation is limited to the domain of education only. If the parents are not motivated to use or inspired to study the endangered language, school itself only keeps the threatened language as a second language for another generation (Fishman 2001a: 14).

An immersion school for an endangered language is a school where education is instructed in the endangered language itself, and the dominant language of the society is not used at all, except as a foreign language. All the subjects are taught in the endangered language, the written materials, including textbooks and signage, are provided in the endangered language, preferably even the extracurricular activities are held in the endangered language as well. Immersion schools can also provide training and exposure to cultural practices, values, the indigenous knowledge of the environment, and indigenous philosophy, religion and ceremonies, such as traditional singing, rituals or ethnobotanics, and, as part of the school activities, excursions can be made to visit actively used sites of language or culture. The first immersion schools for endangered languages were pre-schools or language nests, based on the concept that the grandparent generation together with this type of education can substitute the missing generation of parent-age speakers. While language nests give the children opportunity to acquire the endangered language as their mother tongue, the results of language nests may be quickly outweighed if the continuation of the education in the endangered language is not possible (Hinton 2011: 298-299).

Total immersion programs are considered the best option for revitalising a language. These programs operate according to the underlying concept of providing a monolingual environment in the language of instruction. Nevertheless, the implementation of such programs is not always possible, they are better suited for communities where there are enough speakers available to create the immersion environment. These programs also need widespread support from community members in not only creating but also maintaining a speaking environment (Grenoble and Whaley 2006: 51).

Partial immersion programs are bilingual programs with some classes, mostly language classes, conducted in the revitalised language, while the others are taught in the language of wider communication. The most basic problem of partial immersion programs is that they are often used as transitional bilingual programs, and the minority language is taught as a foreign or second language. This is the most frequently observed model, in particular in certain parts of the world such as the Americas and the former Soviet Union (Grenoble and Whaley 2006: $55)$. 
The models mentioned are characterised by a view of education focusing on the classroom setting, but different educational approaches are practiced in many native cultures or desired by certain communities. Many communities prefer to use informal learning styles (Grenoble and Whaley 2006: 58-59). The master-apprentice program was developed in 1992 in California, for a situation characterised by a relatively large number of indigenous languages with very few speakers and no real language vitality, where, thus, turning to a community of speakers to engage in the effort of starting immersion programs would be impossible (Grenoble and Whaley 2006: 60).

Language reclamation refers to the revival of languages which are no longer spoken. This process has been given a variety of names, such as reclamation, resuscitation, awakening or revival, emphasising the fact that these languages have no native speakers left. Grenoble and Whaley cite Paulston et al. (1993: 276) mention Hebrew as "the only true example of language revival" (Grenoble and Whaley 2006: 63).

The Lylyng Soyum Centre, the headquarters for urban Mansi language revitalisation attempts, is introduced in Chapter 10.

\subsubsection{New speakers}

New speakers are learners of an endangered language who did not acquire the language through intergenerational transmission in the home or within the local community but learnt it through the education system or as adult learners, often through the means of revitalisation programmes and activities (Brennan and O'Rourke 2018: 8). The level of language competence achieved by these new speakers may correspond broadly to the various levels from low to higher fluency, while some new speakers could even reach the level of young fluent speakers. These new speakers, as opposed to native speakers may include language learners who are outsiders to the language community (Grinevald and Bert 2011: 52). Language shift and globalisation make intergenerational language transmission problematic in the case of endangered languages, and the social changes appearing as the result of these processes often result in having a number of potential speakers living in towns and cities instead of staying in the rural areas of their origin, as well as having new speakers using the standard or literary form of an endangered language instead of a local variety (Dołowy-Rybińska 2020: 119-120). New speakers of indigenous endangered languages often may outnumber native speakers (Brennan and O’Rourke 2018: 9) 
Hornsby associates the movement of operating schools offering education in a local indigenous minority language with the growing number of non-heritage, second language learners participating in these programs, whom he also regards as new speakers of given indigenous minority languages (Hornsby 2015: 1-2).

Following Dołowy-Rybińska, who distinguished new speakers from heritage language learners by having new speakers using the language at least to some extent (Dołowy-Rybińska 2020: 120), I regard as new Mansi speakers those Mansi heritage language learners who during their studies gained the ability to have productive skills. I would regard as new Mansi speakers second language Mansi learners with productive skills as well, however, during my fieldwork I met no such a person at all. 


\section{Research history}

\subsection{Ob-Ugric language vitality}

Since literature on language endangerment or language vitality is almost entirely devoid of works recording the sociolinguistic situation of indigenous peoples in Russia, it is not surprising that no comprehensive studies have been conducted on the situation of the Mansi language and Mansi speakers either. The few short reports published by Russian authors (e.g. Skribnik and Koshkaryova 1996, Сподина 2011) often mention data on the two Ob-Ugric languages, Khanty and Mansi, together, making it difficult or impossible to apply the conclusions to the Mansi speakers only. On the other hand, authors do not generally distinguish between the language use experienced among Mansis living in the traditional territories and the multiethnic cities.

It is not only linguistic analysis of the language used in the cities or the detailed descriptions of different aspects of language use that are missing, but researchers lack the most elementary statistical data concerning speakers as well. Csepregi's exemplary 2018 study notes that three of the 13 northern dialects are used in everyday life while considering the Middle $\mathrm{Ob}$ variety extinct, and she also presents an interpretation of the 2010 census data. While 30,943 people professed to be of Khanty ethnicity, 9,584 people stated that they speak the Khanty language, without specifying the subgroup these people belonged to or the variety they spoke. Csepregi states that approximately 3,000 of the total number may be speakers of the Surgut variety and cites Pesikova (Чепреги 2017) estimating the number as follows: 600 Khanties are living along the Yugan, 350 along the Pim, 850 along the Tromagan, and 600 along the Agan rivers, while there are 30 Khanties around Numto, 200 more along the Salym river, 60 Khanties along the Demyanka, and 50 along the Pur river. Regarding the towns and cities she reports that 20 Surgut Khanties live in Surgut, 10 each in Neftyeyugansk, Langepas, Sitomino, and KhantyMansiysk, 6 in Pity-Yakh, and 5 in Nizhnevartovsk (Csepregi 2018: 14). Explaining the census data she notes that the speakers' residence affects the level of their bilingualism as well as their Khanty language use, also pointing out that only the oldest and youngest Khanty speakers have no proficiency in Russian, since Russian has already penetrated every geographical location and domain of language use (Csepregi 2018: 16). Unfortunately, no similar report on the distribution of Mansi inhabitants and Mansi speakers is likely to appear until Norbert Szilágyi publishes the data he collected during his momentous field trip among the Mansi of the KhantyMansi Autonomous Okrug in 2017-2018. 
3.2. Ob-Ugric language education

While no comprehensive studies or case studies are available on Mansi language teaching, there are a handful of shorter articles describing the situation and problems of indigenous language teaching of the Khanty language (e.g. Jääsalmi-Krüger 1998 and Ventsel and Dudeck 1998), and more broadly on the educational situation of the peoples of the Arctic in Russia (e.g. Bartels and Bartels 1995).

Among the various topics, language teaching, as the crossroads of language use, language acquisition and language planning have the richest literature. Touluze's invaluable 1999 report on the founding of literacy and institutionalised education in Western Siberia is especially important for citing all the Russian resources and authors, largely unavailable in the Eastern and Northern European libraries. She mentions that both literacy and education arrived in Western Siberia with Christianity and missionary activity, thus, the gospel according to Matthew became the first known text translated into Mansi, and monastery schools served as the base of the educational system. By 1897 there were already 453 literate Mansis in the Konda region, among whom 4 had reached more than elementary education (Touluze 1999: 4). She cites Shumikhin and Borisova (1975) stating that there were only four schools in Northwestern Siberia in 1915, and according to Budarin (1952) they were attended by only 15 Khanty and Nenets children. The main problem of establishing the Soviet school system was the lack of cadres, and Toulouze cites Skachko (1931) mentioning that in 1923 the People's Comissariat of Nationalities asked the party leadership in Tobolsk for a literate Khanty but received the answer that "there was one, but he died in the civil war" (Toulouze 1999: 8). In 1926-27, according to the central statistics, $5.2 \%$ of the Khanty, $5.6 \%$ of the Mansi and $0.6 \%$ of the Nenets were literate, while the corresponding proportion for the peoples of the North was $7.2 \%$. In 1926, five schools were boarding schools, while by the end of the 1920's, there were 32 national schools in the Tobolsk region, 22 of them with Khanty students (280 children), 7 schools for the Mansi (180 children), and one for the Nenets (20 children) (Touluze 1999: 12).

\subsection{Representation of language nests in the Russian press}

The concept of language nest appeared in the Russian everyday discourse in the beginning of the 21 st century, in connection with the founding of the first Karelian language 
nest in 2000 (c.f. Pasanen 2003). The news portals, and later also scholarly literature usually referred to language nests as a typically Finnish language revitalisation tool, often mentioning the famous success story of the Inari Saami language (c.f. Pasanen 2015). The golden age of language nests lasted only a few years in the late 2000s to early 2010s, when further Karelian language revitalisation institutions have been opened («Языковые гнезда» появятся), followed by Veps («Языковые гнезда» спасут...), Komi (В Коми...), Enets, Dolgan, Nganasan and Evenki (Опьт Красноярского края...) language nests.

The Russian authorities started to voice their displeasure at around the same time. The first negative comments came from the regional level, for example, from the then newly appointed head of the Republic of Karelia Aleksandr Hudilainen, who pointed out that Russian being the only official language of the republic, providing preschool education solely in Karelian, Veps or Finnish would be unconstitutional («Языковые гнезда» cnасут...). Later top-level politicians decided to enter the discourse, for example, the minister of culture of Russia Vladimir Medinsky, who gave a speech at the opening of the 6th World Congress of Finno-Ugric Peoples in Siófok, Hungary, in 2012 about Russia being the key impetus behind the maintenance of Finno-Ugric languages since tsarist times («Языковые гнезда»не разрешеньк...), or the director of the department of interethnic relations of the Ministry of Regional Development Aleksandr Zhuravsky, who gave an interview at the same event, emphasising Russia's rich experience in minority language education, which makes the implementation of language nest method impossible (Министр культурь РФ...).

\subsection{Language policy concerning the indigenous peoples of the North}

Due to Zamyatin's achievements, a considerable amount of information and extensive analysis are available on the language policy concerning the minority languages of the Soviet Union and the Russian Federation, as well as the effects this policy had on minority language education. Although he focuses mainly on the republics located in the European part of presentday Russia, his comprehensive descriptions provide a deep insight into the tendencies determining contemporary language vitality and language use in Western Siberia. He points out that since Russian legislation guarantees official recognition of indigenous groups that are smaller in number than 50,000 as "numerically small indigenous peoples of the Russian Federation", thus, only part of the legal and institutional framework is shared by larger- 
numbered and small-numbered indigenous peoples (Zamyatin 2017: 188). According to the Provisions to the Federal Core Curriculum a division of classes into two groups for the purpose of native language teaching and foreign language teaching was planned, demanding a minimum number of students of 25 in urban schools and 20 in rural schools. Thus, three types of language education were retained, the first including both Russian language and literature and the native language and literature; the second introducing languages of the republics as subjects in the obligatory part of the main educational program; and the third devoting more hours of the syllabus to subjects that fall under the obligatory part of the Unified State Exam (such as e.g. the Russian language) at the expense of subjects from the variable part (including native languages). In particular, this concerned the regions and schools that chose a model where Russian is the medium of instruction and the national languages were taught as a subject (Zamyatin 2012: 36-38).

In the Russian Federation, there is currently no instruction provided in the languages of the small-numbered indigenous peoples, they are only taught as subjects. Their teaching is usually organised in local schools in the areas where indigenous peoples reside, including boarding and nomadic schools. Of 40 indigenous languages in the North, only 23 have been taught as compulsory subjects, five as optional subjects, while the rest were not taught at all (Zamyatin 2017: 196). Zamyatin compares the number of students studying indigenous languages as a compulsory subject during the academic year 2001/02 (20,406 students in 284 schools) with the data form the academic year 2012/13 (14,115 students in 215 schools in 2012/13), pointing out that the number of indigenous students learning their language as a subject decreased from 48.7 to 41.5 per cent (Zamyatin 2017: 196). According to the core curriculum, the amount of time allowed per week for teaching the titular language in republics does not usually exceed two hours, which is enough only for introducing the language to the students, but not for developing sufficient competence in it (Zamyatin 2018: 41-42).

\subsection{City as a site}

The ethnographic and anthropological literature on Siberia seems to be primarily focused on reindeer herders, hunters, and possibly fishermen, its research topics almost completely lacking the discussion of the city as a site, although in other regions the city is now one of the most important ethnological areas. Regularly mentioning this deficiency, Nagy (2016) cites Funk (2011) stating that "[i]f we review the list of dissertations and monographs written in the 1990s and 2000s about the Siberian peoples and the peoples of the North of the 
Russian Federation, it is striking that almost without exception they write about reindeer herders, a few about hunters, and rarely about villagers, the inhabitants of larger settlements are exceptionally mentioned, but urban citizens never", then he adds that the ethnographic literature about the Ob-Ugric peoples similarly neglects the urban topics (Nagy 2016: 1; my translation).

Tradition and traditionality are key terms in Siberian studies. Ventsel puts it as follows:

"In Siberia, Russian, Soviet and Western scholars have largely studied - and continue to study - communities, and the many aspects of tradition that are perceived as 'traditional'. Tradition is also something that embodies the essence of indigenous cultures for many scholars, indigenous activists and intellectuals. Tradition stands for a whole set of elements, including language, economy, national costumes, technological skills, religious beliefs, certain moral values, and many more. According to such an approach, 'a loss of tradition' automatically means the extinction of indigenous groups."

He also mentions Vitebsky stating at a conference in 2003 that Western scholars follow in the footsteps of Soviet ethnographers, as they go to the tundra and the taiga, and tend to ignore that Siberia is an industrial region where the level of urbanisation is extremely high (Ventsel 2009: 8).

Ethnic youth as a research group attracts even fewer researchers. Ethnic youth form a heterogeneous group, only a part of them live in so-called traditional ways, that is, hunting, fishing, or herding reindeer. Ventsel names a few of studies, but at the same time criticises them for giving mainly just quantitative data without an explanation of "how to perceive youth as a group different from children and adults and derive from the Soviet sociological traditions which [sic!] aim was simple - to study youth in order to "increase the effectiveness" of educating, controlling and forming the life paths of young people" (Ventsel 2009: 8). The same tendencies are true about the linguistic, sociolinguistic research of indigenous Siberian languages, especially the Ob-Ugric languages. 


\section{Research methods}

\subsection{Ethical considerations}

Just as the various kinds of linguistic research require different and differently applied research methods, they also raise very different ethical issues, thus no comprehensive ethical rules can be set, only guidelines and key concepts may be given. In this chapter the key ethical issues considered during fieldwork (following Eckert 2014) and their analysis are overviewed, followed by the preferred personal guidelines.

Research on underdocumented, endangered language necessarily involves cooperation with speakers, participants, and consultants. During my fieldwork I tried to turn to the largest possible number of consultants and not to refuse anyone who volunteered to discuss my research topic with me. This often led me into the middle of the smaller and larger conflicts suffusing the everyday life of a small community, and since participating in the conflicts would desperately limit the success of my research, I tried to tell my general, theoretical opinion when asked to, but not to commend individual behaviours or take sides in arguments.

I described my research questions to the consultants every time, asked for their permission to record their answers with a small digital recorder and to quote it later during my scientific work. As far as I am informed, every consultant took part in research not only out of consent but also voluntarily. I informed consultants every time about their right to interrupt the interviews and observations at any time and to revoke their consent to record them or to quote them during recording as well as at any time afterwards. I informed them that I shall cite their statements anonymously. Because of the intimate nature of the issues researched and the unfriendly political situation, I decided not to ask consultants to sign consent forms. I did not ask for prior permission when taking photos, because spontaneous photographs served my research better, and the consultants could check and delete the undesirable images after the session. This behaviour raised no conflict during the fieldwork, on the contrary, knowing that I always carried a camera with me, the consultants often requested that I take photos or short videos even on occasions when I had not intended to use the camera. On the rare occasion when our understanding of privacy turned out to differ, consultants warned me not to take photos before the activity started. 
While language documentation usually demands very straightforward collaboration between researcher and speaker, sociolinguists often prefer to de-emphasise their actual research questions in order to receive as unselfconscious answers as possible. The institutional background of research and researcher may affect the perception of the researcher's behaviour as well. During my fieldwork I tried to give brief and simple explanations about my research questions, if necessary, enumerating various possible answers and international examples, carefully hiding my expectations. Officially being a foreign exchange student at the local university from a post-socialist country was a very fortunate setting easily understood and accepted by every consultant, creating no conflicts and evoking only positive stereotypes.

Although consultants are usually aware of the fact that informants may receive a fixed sum or salary for participating in research, paying consultants is not yet an accepted practice in the Khanty-Mansi Autonomous Okrug. The consultants' position as the owners of knowledge apparently does not allow them to accept financial compensation, thus, transaction was limited to objects not forming the direct subject of the research (e.g. purchasing artefacts), while mutual souvenirs had been changed to strengthen agreeable relationships, and since the consultants were not interested in receiving the records of the interviews or the scientific paper resulting from them, the scientific part of the relationship was maintained by providing the consultants with various digital materials on Ob-Ugric languages and cultures available outside Russia. Just as in the case of the previous research projects carried out on the same topic at the same domains, I plan to translate the final work into Russian and to make it available to the Lylyng Soyum Centre and, on demand, to the library of the Ob-Ugric Research Institute.

During the analysis of the data collected during fieldwork, I decided to anonymise the interviews and refer to the consultants solely by numbers (e.g. "Consultant 12"). Although throughout the literature of sociolinguistics and anthropology it is accepted to mention informants by code referring to their sex, age, and often place of birth or residence, because of the complicated political situation in Russia I preferred to use the simplest way to differentiate between consultants. Recently a similar decision has been made by other researchers as well (e.g. Németh 2018). The table summarising the basic sociolinguistic data of the consultants cooperating during the research used in the present thesis is provided in the Appendix.

\subsection{Sampling}


While random sampling is often viewed as the surest way of providing equal probability of selection and regarded as ensuring representative results, thus permitting extrapolation from the sample to the entire community, a more populous speakers' community than the size of the Mansi community of Khanty-Mansiysk is necessary for applying.

The uneven distribution of observed populations in itself makes it impossible to achieve representativity. Thus, instead of random sampling, the snowball sampling method was applied during the fieldwork. Although this approach is usually more time consuming in terms of the time investment needed in order to enter the network as well as the emotional involvement required to operate within it, in the particular cases of my fieldwork I was fortunate enough to be introduced to many members of the Mansi community of Khanty-Mansiysk already at the beginning stage, and being recommended by relatives, friends and colleagues, the proposal of co-operation was very rarely refused by new potential consultants. According to Buchstaller and Khattab, the general rule of thumb for the social sciences would require reaching $3 \%$ to be regarded as representative (Buchstaller and Khattab 2014: 82), thus the approximately 100 members (for a detailed list of consultants, see the Appendix) of the Mansi community of Khanty-Mansiysk contacted during the fieldwork may be regarded representative.

By contacting the consultants I mean getting into contact with them in person (almost exclusively during the various periods of fieldwork, in the Khanty-Mansi Autonomous Okrug), or if necessary, with the help of online tools. By contacting them in person I mean meeting them deliberately at their work place in order to observe them during their work or in order to ask for an interview with them, as well as visiting them at their homes at their invitation, also including the occasions in the list of contacts when we met accidentally. It is nearly impossible to give a comprehensive description of who was contacted, when and under what circumstances, since the intensity and character of these contacts have been rather varied. I met Consultant 112 only once in October 2006, when he was visiting his aunt, Consultant 3. Consultant 3, on the other hand, is somebody I met several times. For example, just to make a summation of the 2015 fieldwork only, I visited her home five times: once to celebrate her daughter's birthday (with Consultants $1,4,8,9,10,11,65,66,68,69,108$ and 110 attending the same party), once to attend my farewell party (with Consultants 1, 4, 8, 9, 11 attending the same party), two times to make an interview with different family members, when it turned out that they were out, thus I stayed for dinner and informal conversation, and once to finally make the interview with one member of Consultant 3's household (with Consultants 1, 4 and 10 at home all three times). I visited Consultant 3 at her workplace twice to make an interview with her (with Consultants 
15,17 , and 21 around), and I met her at her workplace two other times when I arrived to visit her colleagues (with Consultants 14, 17, and 23 around, although Consultant 14 ended up refusing to participate in the study in question). I occasionally met Consultant 3 at a reception (with at least 25-30 consultants in the same company), and twice when she was arriving to pick up her daughter at the Lylyng Soyum Centre. Besides that we exchanged approximately 50 messages on a Russian social networking site.

\subsection{The sociolinguistic interview}

One of the most important tools for collecting data on language in its social setting is the sociolinguistic interview, where the recordings are overt, while the questions are designed to distract interviewees from focusing on specific linguistic forms and towards producing connected speech about topics of interest (Schilling 2014: 107-108). According to Levon, ethnographic interviews are similar to semi-structured sociolinguistic interviews, though they often lack the requirement of strict comparability and elicitation of a style range (Levon 2014: 210).

I carried out interviews with approximately 40 people about their history of language acquisition and language use as well as their opinion about the role of the Mansi language in Khanty-Mansiysk and the possible future of the language. The interviewees were employees of the institutions mentioned in section 5.2.2 or their immediate family members. The interviews lasted between 30 and 60 minutes each, were conducted in Russian, and recorded with a small digital recorder. The interviews were ethnomethodological interviews in their content, semistructured interviews according to the form-content constraints, individual and in some cases double interviews according to the framework of the interaction. As in qualitative interview situations in general, it was characteristic of this interview situation that the consultant acted not only as an interviewee but also as active collaborator (Szokolszky 2004: 459).

\subsection{Participant observation}


Participant observation is the primary data collection method of ethnographic and anthropologic research as well as of qualitative sociolinguistics. In practical terms, this means that the researcher takes part in as many activities of the observed group as possible, including formal and informal occasions as well (Levon 2014: 204-205). Because of the difficulties of multitasking, it is advisable to record the events observed. Since participant observation means more or less the direct and complete observation of a phenomenon, during the participant observation the researcher can validate the data obtained in the interviews, that is, they may check the examined attitudes and statements in practice, and on the other hand, they may come across data or tendencies not recalled in an interview situation (Babbie 2010: 327-328).

During observation, the researcher tries to observe social phenomena in their natural form, with the least possible influence by the informants (Szokolszky 2004: 419). The methodology of participant observation has remained essentially unchanged since its inception, and its theoretical framework has been determined by two major theoretical debates, on the one hand, discussing the asymmetry between researchers and scholars, on the other hand, regarding the definition of culture. As a result of the latter discussion and Geertz's Thick Description (Geertz 1973), the so-called interpretive approach emerged, focusing on the dual role of the researcher, the paradox of exclusion and inclusion, and the resulting interpretive task for the researcher (Letenyei 2005: 77-78). During participant observation, the observer carries out their research openly, exposing the position of researcher, and works according to predefined goals and criteria but without predefined or tightly defined categories (Szokolszky 2004: 432-433).

Although participant observation is exceptional in terms of the depth and quality of the data produced, it is extraordinarily time-consuming, and most researchers estimate an outcome ratio of at least 10:1, that is, ten hours of fieldwork resulting in one hour of recorded data (Buchstaller and Khattab 2014: 80). In addition to participant observation and interviews, the ways of collecting linguistic and social information include self-recording and collection of community artefacts. In the case of sociolinguistic fieldwork, self-recording mostly means keeping a diary, in written or in digital form, while by community artifacts physical materials such as images, broadcasts or other media products are understood (Levon 2014: 211).

I have spent approximately 18 months in the Khanty-Mansi Autonomous Okrug during fieldwork carried out between 2006 and 2019. During this period, I had the opportunity to carry out participant observation in nearly all of the important domains of language use in KhantyMansiysk. The Lylyng Soyum Centre, the (unfortunately closed) department of Mansi philology at Yugra State University, and the editorial offices of the Mansi newspaper Luima Seripos proved to be most important and central during the fieldwork. I observed classes at the 
department of Mansi philology at Yugra State University and the Lylyng Soyum Center as a student, I visited the department of Mansi philology at Yugra State University and the editorial offices of Luima Seripos as a visiting researcher, while I was able to visit the Office of Educational Development as a researcher. In addition to providing an insight into their work, the employees of these places also aided me by providing their family relationships and social network, thus making possible for me to get a more accurate picture of Mansi language use in Khanty-Mansiysk.

\subsection{Transcription}

While recording language samples or interviews, the researcher needs to make decisions regarding the transcription of voice recordings. The first decision is whether to transcribe the recordings at all, to transcribe only relevant passages, or to present all the available materials in text form. Researchers need to make ethical decisions regarding how much personal information to transcribe, and how to respect the anonymity promised to research participants. Names of speakers and individuals mentioned are often excluded, but further identifying information may also need to be eliminated or altered (Nagy and Sharma 2014: 236-238). Another relevant question regarding transcription in the choice of orthography or transcription system. Following contemporary practices regarding transcriptions, I provide the transcription of spoken Mansi texts in IPA, while out of respect for Mansi as a language, with literacy and standardised forms, I also give the same texts according to Mansi orthography as well.

\subsection{Statistical data}

The integrated results of the 2002 and 2010 Russian censuses were collected by me from the official website of the censuses, while the data from the same censuses limited to the Khanty-Mansi Autonomous District, and well as the statistics on public education and the social situation of minorities ${ }^{2}$ in the Khanty-Mansi Autonomous Okrug were obtained from the Regional Statistical Office and the Education Development Office in Khanty-Mansiysk.

\footnotetext{
${ }^{2}$ Especially the latter proved to be essential because since 2015 these statistics have been removed from the home pages of these offices.
} 


\section{The field}

\subsection{Community of research: The Mansi}

\subsubsection{Historical data}

As one of the most reliable sources on the size of the Mansi population prior to the Soviet censuses, Kannisto lists 4,886 Mansis in the territories he managed to reach at the beginning of the $20^{\text {th }}$ century (cf. Kannisto and Nevalainen 1970). All of his informants were also speakers of the Mansi language, since Kannisto did not add to his list those who had been living married to Russians (or people of other ethnicities) and had not raised their children as Mansi monolinguals.

Since 1926, the first census carried out in the territory of the whole Soviet Union, the size of the Mansi population has been constantly rising, while the number of speakers, oscillating until 1970, started to quickly decrease and continue to do so ever since (see Table 7). Keeping the questionable reliability of censuses in mind, the data of the 2020 Russian census may give an answer to many questions proposed in the present thesis paper.

\begin{tabular}{|c|r|r|}
\hline YEAR & MANSI POPULATION & SPEAKERS OF THE MANSI LANGUAGE \\
\hline $1926^{3}$ & 5,754 & - \\
\hline $1939^{4}$ & 6,315 & $\sim 3,820$ \\
\hline 1959 & 6,318 & $\sim 4,040$ \\
\hline 1970 & 7,609 & 3,742 \\
\hline 1979 & 7,434 & 3,184 \\
\hline 1989 & 8,279 & 2,746 \\
\hline 2002 & 11,432 & 938 \\
\hline 2010 & 12,269 & \\
\hline
\end{tabular}

\footnotetext{
${ }^{3}$ The Mansi were listed under the name "Voguls", no information was available on the number of speakers (Census SU 1926).

${ }^{4}$ No information was available on the number of speakers (Census SU 1939).
} 
Table 7. Census data regarding those declaring themselves to be of Mansi ethnicity (1926-2010) and the number of speakers of the Mansi language (1959-2010)

Paying attention to the data of the two censuses carried out after the collapse of the Soviet Union, the decreasing number of Mansi speakers (2,746 speakers in 2002, and only 938 speakers in 2010) and the emerging number of those declaring themselves as belonging to the Mansi ethnicity (11,432 people in 2002, and 12,269 people in 2010) (Sipöcz 2005, Census RF 2010 4/1 and Census RF 2010 4/5) are even more prominent. The possible reasons behind population growth are usually identified as the rising proclivity to declare anyone with a partly or completely Mansi family background as a Mansi, as well as the financial support given to the representatives of the indigenous peoples of the North (Németh 2018: 81).

\begin{tabular}{|c|c|c|}
\hline YEAR & MANSI POPULATION & $\begin{array}{c}\text { RATIO OF MANSI POPULATION LIVING IN } \\
\text { URBAN SETTLEMENTS }\end{array}$ \\
\hline 1959 & 6,318 & - \\
\hline 1970 & 7,609 & - \\
\hline 1979 & 7,434 & - \\
\hline 1989 & 8,279 & $45.6 \%$ \\
\hline 2002 & 11,432 & $51.8 \%$ \\
\hline 2010 & 12,269 & $57.3 \%$ \\
\hline
\end{tabular}

Table 8. Census data regarding those declaring themselves to be of Mansi ethnicity, and the ratio of Mansi population living in urban settlements (1959-2010)

The interpretation of the data on the number of speakers is also problematic. Several circumstances are responsible for the low proportion of Mansi speakers in relation to the Mansi population. One of these possible causes is the controversial understanding of the concept of first language. Although the term "native tongue" is used in the local scientific discussions according to the general traditions, that is, understanding the native language (родной язык) to be the speaker's primarily language, first acquired language, the language of early childhood, it is well known that "the question of the meaning of the concept of 'native language' has always 
caused heated discussion" (Хакназаров 2013: 83; my translation), and among the representatives of indigenous, minority languages the term is used in the meaning of the language correlating with one's nationality, the language of one's ancestors. Thus, while some respondents may decide not to state having a native tongue different from Russian, others may refer to an indigenous language as their first language despite of not being able speak it. Either way, based on changes occurring after the 2002 census, it can be stated that the demographic situation of the Mansi has changed in the last hundred years at least as radically as the situation of the Vasyugan Khanties (cf. Nagy 2007: 17-31).

According to the findings of the 9-month-long fieldwork carried out by Norbert Szilágyi in the Khanty-Mansi Autonomous Okrug in 2016 and 2017, the number of speakers presented in the 2010 Russian federal census is approximately accurate. The researcher, having visited the Konda, Ob, Sosva and Lyapin regions, reported the middle-aged speakers from the MiddleSosva as the largest subgroup, with approximately 200-400 speakers ${ }^{5}$.

Regarding the data available on the ratio of Mansi population living in urban type of settlements compared to the total population, the growing importance of the urban population is visible, by 2010 almost $60 \%$ of the Mansi population have been living in urban centres (See Table 8).

\subsubsection{Data from the 2010 Federal Census}

According to the results of the 2010 Federal Census, there were 12,269 Mansis (5,590 men and 6,679 women) living in the territory of the Russian Federation, 7,028 of them in cities (3,115 men and 3,913 women), while 5,241 Mansis (2,475 men and 2,766 women) lived in other types of settlements (Census RF 2010 4/1) at the time. A total of 11,614 Mansis lived in the territory of the Tyumen Oblast, ${ }^{6} 10,977$ of them in the Khanty-Mansi Autonomous Okrug

\footnotetext{
${ }^{5}$ Personal communication.

${ }^{6}$ 5,414 men and 6,459 women, 6,588 (2,911 men and 3,677 women) of whom live in cities and 5,026 people (2,372 men and 2,654 women) live in other types of settlements.
} 
- Yugra, ${ }^{7}$ and 166 Mansis lived in the Yamal-Nenets Autonomous Okrug ${ }^{8}$. Another 251 Mansis lived in the Sverdlovsk Oblast, ${ }^{9}$ and 8 in the Komi Republic ${ }^{10}$ (Census RF 2010 4/19).

Among those respondents who made a declaration about their native tongue during the 2010 census, 1,790 stated to have Mansi as their first language. Little is known about the ethnic categorisation of these people, but among the representatives of what is called the "major ethnic groups" 5 Russians, 2 Maris and 1 Komi stated to have Mansi as their mother tongue (Census RF 2010 4/8).

From the 11,614 Mansis living in the territory of the Tyumen Oblast, 11,584 answered the question about mother tongue, and 9,891 gave Russian as their first language, 15 Khanty, and $15 \mathrm{Komi}$, while 6 people gave other, unlisted languages. A total of 1,657 Mansis professed to have Mansi as their mother tongue. Of the 10,977 Mansis living on the territory of the Khanty-Mansi Autonomous Okrug - Yugra, 10,949 answered the question about their mother tongue, and 9,344 gave Russian as their first language, 14 Khanty, and 14 Komi, while 3 other persons gave other, unlisted languages. All in all, 1,574 Mansis stated to have Mansi as their mother tongue. Of the 166 Mansis living on the territory of the Yamal-Nenets Autonomous Okrug, 133 gave Russian as their first language, 1 gave Khanty, and 1 Komi, while 31 Mansis professed to have Mansi as their mother tongue (Census RF 2010 4/23).

Of the 12,269 Mansis living in the territory of the Russian Federation, 12,251 professed to be able to speak Russian, 7,018 of them living in cities and 5,233 in other types of settlements (Census RF 2010 4/3). Of the total, 12,238 Mansis answered the question about their mother tongue: 10,426 professed to have Russian as their first language, 15 Khanty, 17 Komi, 1 Mari,

\footnotetext{
7 5,027 men and 5,950 women, 6,080 (2,697 men and 3,383 women) of whom live in cities and 4,897 people (2,372 men and 2,654 women) live in other types of settlements.

${ }^{8} 64$ men and 102 women, 115 (48 men and 67 women) of whom live in cities and 51 people (16 men and 35 women) live in other types of settlements.

${ }^{9} 127$ men and 124 women, 125 (58 men and 67 women) of whom live in cities and 126 people (69 men and 57 women) live in other types of settlements.

104 men and 4 women, 5 ( 2 men and 3 women) of whom live in cities and 3 persons ( 2 men and 1 woman) live in other types of settlements.

${ }^{11}$ Of the "largest ethnic groups" (наиболее многочисленных национальностей), in this section the following ethnic groups were listed: Russians, Tatars, Ukrainians, Bashkirs, Chuvashes, Chechens, Armenians, Mordvins, Kazakhs, Azeris, Dargins, Udmurts, Maris, Ossetians, Belarusians, Kabardians, Kumyks, Yakuts (Sakha), Lezgins, Buryats, Germans, Uzbeks, Tuvans, Komis, Karachays, Romanis, Tajiks, Kalmyks, Laks, Georgians, Jews, Moldovans, Koreans, Tabasarans, Adygheans, Balkars, Turks, Nogais, Kyrgyz, Komi-Permyaks, Greeks, Altaians, Cherkesy, Khakas, and Karelians.
} 
1 Uzbek, and 5 some other, unlisted language, whereas 1,773 Mansis stated that they had Mansi as their mother tongue (Census RF 2010 4/22). A single Mansi speaker was living in the Krasnodar Krai, ${ }^{12} 1$ in the Leningrad Oblast, ${ }^{13} 1$ in the Tomsk Oblast, ${ }^{14} 4$ in the Chelyabinsk Oblast, ${ }^{15}$ and 2 in Saint Petersburg ${ }^{16}$ (Census RF 2010 4/23). A total of 938 people in the Russian Federation stated that they spoke the Mansi language (Census RF 2010 4/5), and only 834 of them were of Mansi ethnicity (Census RF 2010 4/20).

As many as 12,257 Mansis answered the question about their competence in foreign languages: 1 of them spoke Arabic, 8 spoke Armenian, 1 Bashkir, 2 Belarusian, 1 Chuvash, 273 English, 1 Finnish, 12 French, 2 Georgian, 82 German, 5 Hungarian, 1 Italian, 1 Japanese, 3 Kazakh, 24 Khanty, 1 Kyrgyz, 3 Komi, 1 Latin, 6 Mari, 4 Nenets, 1 Swedish, 3 Spanish, 2 Tajik, 6 Tatar, 3 Udmurt, 9 Ukrainian, 3 Uzbek, 1 Yakut, and 5 persons spoke other, unlisted languages (Census RF 2010 4/20).

5.1.3. Data from the 2010 Federal Census regarding the Khanty-Mansi Autonomous Okrug Yugra

According to the 2010 Federal Census, 10,977 Mansis were living in the territory of the Khanty-Mansi Autonomous Okrug - Yugra, 3,457 of them in the Berezovskiy rayon, 3,584 in the Kondinskiy rayon, 12 in Nefteyuganskiy rayon, 49 in Nizhnevartovskiy rayon, 439 in Oktyabrskiy rayon, 167 in Sovetskiy rayon, 56 in Surgutskiy rayon, and 173 in the KhantyMansiyskiy rayon. In addition to these rayons, Mansis also were residing in towns and cities of the Okrug, namely, 18 of them in Kogalym, 22 in Langepas, 22 in the region of Megion and 15 more in Megion, 60 in Nyagany, 72 in Nyefteyugansk, 156 in Nizhnevartovsk, 192 in the region of Beloyarskiy and 71 more in Beloyarskiy, 11 in Raduzsniy, 256 in Surgut, 917 in Uray, 1208 in Khanty-Mansiysk, 51 in Yugorsk, 87 in Sovetskij, and 16 in Lyantor (Census HMAO 2010 4).

\footnotetext{
${ }^{12}$ Of 19 ethnic Mansis, 18 gave Russian as their mother tongue.

${ }^{13}$ Of 12 ethnic Mansis, 11 gave Russian as their mother tongue.

${ }^{14}$ Of 22 ethnic Mansis, 21 gave Russian as their mother tongue.

${ }^{15}$ Of 22 ethnic Mansis, 18 gave Russian as their mother tongue.

${ }^{16}$ Of 35 ethnic Mansis, 33 gave Russian as their mother tongue.
} 


\begin{tabular}{|c|c|c|}
\hline & RUSSIAN FEDERATION & $\begin{array}{c}\text { KHANTY-MANSI } \\
\text { AUTONOMOUS OKRUG }\end{array}$ \\
\hline Ethnic Mansi & 12,269 & 10,977 \\
\hline \multicolumn{3}{|l|}{ of them, speak as mother tongue } \\
\hline Russian & 10,426 & 9,344 \\
\hline Mansi & 1,773 & 1,582 \\
\hline \multicolumn{3}{|l|}{ of them, with proficiency in } \\
\hline Russian & 12,251 & $?$ \\
\hline Mansi & 834 & 682 \\
\hline
\end{tabular}

Table 9: Summarising 2010 census data regarding the ration ethnic Mansi, respondents with Mansi or Russian mother tongue and respondents having proficiency in Mansi and Russian

Among those who answered the question about their native tongue, 1,582 professed to have Mansi as their first language. Little is known about the ethnic categorisation of these people, but among the representatives of what is called in Russia the "major ethnic groups", ${ }^{17}$ 2 Russians, 1 Maris and 1 Komi professed to have Mansi as their mother tongue (Census HMAO 2010 8).

Of the 10,977 Mansis living in the territory of the Khanty-Mansi Autonomous Okrug Yugra, 10,949 indicated their native languages: 9,344 Mansis professed to have Russian as their first language, 1 named Uzbek, 14 Khanty, and 16 named other, unlisted languages. Only 1,574 Mansis gave Mansi as their mother tongue (Census HMAO 2010 9).

Among the Mansi residents of the Khanty-Mansi Autonomous Okrug - Yugra, only a handful of people were found who were unable to speak Russian: 3 in Berezovski rayon, 2 in

\footnotetext{
${ }^{17}$ Of the "largest ethnic groups" (наиболее многочисленных национальностей), in this section the following ethnic groups were listed: Russians, Tatars, Ukrainians, Bashkirs, Chuvashes, Chechens, Armenians, Avars, Mordvins, Kazakhs, Azeris, Dargins, Udmurts, Maris, Ossetians, Belorusians, Kabardians, Kumyks, Yakuts (Sakha), Lezgins, Buryats, Germans, Uzbeks, Tuvans, Komis, Karachays, Romanis, Tajiks, Kalmyks, Laks, Georgians, Jews, Moldovans, Koreans, Tabasarans, Adygheans, Balkars, Turks, Nogais, Kyrgyz, Komi-Permyaks, Greeks, Altaians, Cherkesy, Khakas, and Karelians.
} 
Kondinskiy rayon, 1 in Oktyabrskiy rayon, also one each in Megion, Nizhnevartovsk and Uray, 4 in Pyty-Yakh, and 3 in Yugorsk (Census HMAO 2010 4).

In the Khanty-Mansi Autonomous Okrug - Yugra, only 757 people professed to speak the Mansi language (Census HMAO 2010 5). Little is known about the ethnic categorisation of these people, but among the representatives of what is called the "major ethnic groups" ${ }^{18} 15$ Russians, 27 Komis, 1 Komi-Permyak, and 1 Udmurt professed to speak Mansi (Census HMAO $20106)$.

Of the 10,977 Mansis living in the Khanty-Mansi Autonomous Okrug - Yugra, 10,969 people indicated their foreign language proficiency: 10,966 professed to speak Russian, 7 Ukrainian, 2 Tatar, 54 German, 1 Azeri, 2 Uzbek, 1 Chuvash, 1 Kyrgyz, 8 Armenian, 21 Khanty, 6 Mari, and 233 gave other, unlisted languages. Only 682 Mansis stated that they were able to speak Mansi in the territory of the Khanty-Mansi Autonomous Okrug (Census HMAO 2010 7). For a summary of the most important 2010 census data, see Table 9.

\subsection{The locus of data collection: Khanty-Mansiysk}

\subsubsection{Demographical data}

According to the 2002 Russian census, the largest ethnic group living in the KhantyMansi Autonomous Okrug were Russians (66.1\%), while $8.6 \%$ of the population were Ukrainians, and 7.5\% were Tatars. Among the remarkably high number of 123 nationalities residing in the district, the Mansi make up only $0.7 \%$ of the population. According to the 2010 census, the largest ethnic group was the Russians (68.1\% of the population), $7.6 \%$ of the district's population was Tatar, $6.4 \%$ were Ukrainian, while $1.8 \%$ were Azerbaijani (Census RF 2002 3, Census RF 2010 7).

\footnotetext{
${ }^{18}$ наиболее многочисленных национальностей, in this section the following ethnic groups were listed: Russians, Tatars, Ukrainians, Bashkirs, Chuvashes, Chechens, Armenians, Avars, Mordvins, Kazakhs, Azeris, Dargins, Udmurts, Maris, Ossetians, Belarusians, Kabardians, Kumyks, Yakuts (Sakha), Lezgins, Buryats, Ingushes, Germans, Uzbeks, Tuvans, Komis, Karachays, Romanis, Tajiks, Kalmyks, Laks, Georgians, Jews, Moldovans, Koreans, Tabasarans, Adygheans, Balkars, Turks, Nogais, Kyrgyz, Komi-Permyaks, Greeks, Altaians, Cherkesy, Khakas, Karelians.
} 
While the Mansi form only $0.72 \%$ of the population of the Khanty-Mansi Autonomous Okrug, their proportion is twice as high in the city of Khanty-Mansiysk, where the Ob-Ugric peoples together give $3.7 \%$ of the population. Mansis have been migrating to the capital of the Khanty-Mansi Autonomous Okrug from the traditional Mansi territories since the second half of the $20^{\text {th }}$ century, since, as a result of the industrial and economic boom of the district, they moved to cities. This explains the lack of exclusively Mansi institutions or domains of language use in the cities of the Okrug.

\subsubsection{Institutions of Ob-Ugric relevance in Khanty-Mansiysk}

The open-air museum Torum Maa, located on one of the hills of Khanty-Mansiysk, in the Northern part of the city, was founded on the initiatives of the Mansi poet Yuvan Shestalov and the Khanty writer Yeremey Aypin in 1987. In addition to presenting the traditional ObUgric building types, the museum also houses a sacred storehouse on poles, and idols depicting the seven sons of Numi Torem, god of the upper sky, created by the Khanty painter Gennadiy Rayshev. In the buildings a rich ethnographic collection of women's and children's clothes, birch bark, pearls, and fur objects is displayed (Шафранов-Куцев 2000: 281).

The Centre of Arts for the Talented Children of the North ${ }^{19}$ opened in 1997 with the support of A. V. Filipenko, governor of the Khanty-Mansi Autonomous Okrug. Its students were educated in three specialisations: music, art, and choreography. Since 2000, Ural State Academy of Architecture, Moscow State University of Culture and Art, and the Russian Academy of Music have been operating branches in the Centre. In 2000, the Centre was given the title of UNESCO Associated School, and since 2004 it has been the member of the International Society for Music Education. Although in its name the Centre referrs to the children of the indigenous peoples of the North, apart from classes of traditional Ob-Ugric musical instruments, the Centre had had almost no importance in representing or maintaining the languages and cultures of the Ob-Ugric languages already during my first fieldwork, carried out in 2006, still it was necessary to add it to the list of institutions with Ob-Ugric profiles,

\footnotetext{
19 Центр искусств для одарённых детей Севера.
} 
because when enumerating the buildings and institutes created and founded for the Ob-Ugric peoples, the Centre is always mentioned by consultants.

The Pedagogical College ${ }^{20}$ (since 2010, Technical-Pedagogical College of KhantyMansiysk) has the longest history among the institutions of Mansi relevance, training specialists for Mansi and Khanty schools and kindergarten (among others) since 1932. In 2010, in addition to the project entitled "The training of teachers specialising in indigenous minority language and literature", other training programs operated as well, such as "Instrumental music played on sankwaltap ${ }^{21}$ and education of the folklore of the northern peoples", "Socio-cultural activities, folk art and folk dance of the peoples of the North". Operating side by side with the specialisation of Mansi philology at Yugra State University, it attracted a larger number of Mansi students, native and heritage language speakers of Mansi.

The training of future Mansi and Khanty linguists and ethnologists took place at Yugra State University from 2003 to 2010. The program did not exist for long enough to fit into the structure of Ob-Ugric education, while obviously the students attending the programs were unable to fit the training concept, for many of the most talented students left the university to work at the Ob-Ugric Theatre instead, while many of the most committed students continued their studies at the pedagogical college. Following the "temporary" closure of the Department of Mansi philology, until Yuvan Shestalov's death in 2011 the Shestalov Laboratory continued to work with the Mansi language, preparing Munkácsi's Mansi folklore collection for publication. The Centre of the Peoples of the North ${ }^{22}$ opened in 2012, officially and openly leaving indigenous languages out of their agenda.

The Ob-Ugric Research Institute ${ }^{23}$ was created in 2005 by merging the Research Institute of Ob-Ugric studies ${ }^{24}$ and the Regional Archive for the Small Indigenous Peoples of the North. ${ }^{25}$ Residing on two levels of the House of Peoples' Friendship, ${ }^{26}$ originally designed

\footnotetext{
${ }^{20}$ Педагогический колледж (Ханты-Мансийский технолого-педагогический колледж).

${ }^{21}$ A Mansi plucked string instrument.

${ }^{22}$ Центр Народов Севера, originally confusingly called the Institute of the Peoples of the North, Институт Народов Севера

${ }^{23}$ Обско-угорский институт прикладных исследований и разработок, Ob-Ugric Institute of Applied Research and Projects

${ }^{24}$ Научно-исследовательский институт угроведения

${ }^{25}$ Окружной научный фольклорный архив коренных малочисленных народов Севера

26 Дом дружбы народов
} 
to house only institutions with an Ob-Ugric profile, the Research Institute coordinates the research on the indigenous peoples of the Okrug. During my first fieldwork in 2006, the employees of the Research Institute were almost exclusively representatives of the Ob-Ugric people, including, for example, Yevdokiya Ivanovna Rombandeeva. In 2018 and 2019 only four researchers were employed at the Department of Mansi Philology and Ethnology, three of them described as native speakers of Mansi, while one Mansi native speaker worked for the Department of Ob-Ugric Literatures, and one researcher engaged in research concerning Mansi culture worked at the Department of History and Ethnology.

The Theatre of Ob-Ugric peoples ${ }^{27}$ was founded in Khanty-Mansiysk in 2002, with the aim to preserve and develop the folklore and spiritual culture of the indigenous peoples of the Khanty-Mansi Autonomous Okrug, as well as to provide a domain for the development of professional Ob-Ugric theatre. One of the initiators of the foundation was Gennadiy Stepanovich Rayshev, a locally famous painter of Khanty descent, while the first artistic director of the theatre was the Udmurt actress Olga Yakovlevna Aleksandrova. The theatre has been located in the building of the House of Peoples' Friendship, alongside with other Ob-Ugric institutions, and since the original concept included the intent to create an authentic environment and atmosphere, beside a classic theatre hall, the theatre also houses a circular showroom too, to represent the interior of an Ob-Ugric tent. The work began in 2003, the first show premiered in 2004.

The local branch of the Russian State television started to broadcast a Khanty program in 1992, while in Mansi in 1994. Originally the channel featured a Mansi TV program once a week, while the radio channel aired news in Mansi every second day. Both kinds of programs lasted for approximately 30-40 minutes per episode. The local TV channel broadcast news in Mansi for 5-10 minutes every Sunday.

\footnotetext{
27 Театр обско-угорских народов - «Солнце»
} 
6. Ob-Ugric elements in the linguistic landscape of Khanty-Mansiysk

\subsection{Introduction}

This chapter aims to place Mansi and Khanty, that is, the Ob-Ugric languages in the linguistic landscape of Khanty-Mansiysk city, Western-Siberia, Russia. The analysis covers not only all the Mansi written elements displayed in the public spaces of the city, but also other visual signs connected to the Ob-Ugric peoples, such as graphic representations of relatively widely known elements of verbal folklore (folk tales and myths), decorative ornaments, and architectural forms. The small number of signs forming the Mansi and Khanty linguistic landscape does not reach a sufficient amount to make any genre categorisation possible, nevertheless, it allows to outline the various strategies of identity construction taking place in Khanty-Mansiysk.

The signs on the buildings of institutions, communal places, stores, memorials and other sites related to Ob-Ugric people in Khanty-Mansiysk are predominantly in Russian only. There are only a few documented exceptions from the rule of Russian linguistic dominance, written in English, in official languages of some EU member states, and only a few in the Ob-Ugric languages. The complete investigation of the presence of Mansi and Khanty peoples in KhantyMansiysk necessarily includes the investigation of materials containing no text but visual elements too, such as buildings, statues and graffiti.

The data on the linguistic landscape of Khanty-Mansiysk were collected and documented during fieldwork, carried out six times between 2006 and 2015 in the KhantyMansi Autonomous Okrug - Yugra. The data on online use of the Mansi and Khanty languages have been collected via online participant observation, carried out mostly on the two most popular social media sites since 2009. The information on the textual and visual Ob-Ugric elements placed around the city as results of bottom-up initiatives were collected via semistructured interviews with active members and actors of the indigenous circles in KhantyMansiysk (especially with the co-workers of the Lylyng Soyum Centre and the editorial staff of the Mansi newspaper Luima Seripos). 
6.2. Major languages in the linguistic landscape of Khanty-Mansiysk

6.2.1. The Russian language in the linguistic landscape of Khanty-Mansiysk

As mentioned above, Russian is the mother tongue of the ethnically Russian population (68.1\%, Census 2010 7) of the town, most likely also the first language of the vast majority of the various other ethnic groups forming the remaining proportion of the population. Russian is the dominant language of Khanty-Mansiysk, as well as the mediating language of the interethnic families and urban domains (such as e.g. the marketplace). Consequently, it is not surprising that the official, commercial, communal and private signs in the city are to be found exclusively in Russian, and the exceptions to this rule total such a small number that they can be easily enumerated.

\subsubsection{The English language in the linguistic landscape of Khanty-Mansiysk}

The presence of English in the local linguistic landscape has a rather short history. Khanty-Mansiysk attracts tourists to a minimal degree, visitors speaking English and no Russian arrive in the town on the occasion of specific international programs, such as e.g. scientific conferences, art festivals, and sports championships. Signs containing English texts beside Russian are desultorily situated at the location of such events, as e.g. in the biathlon centre. The first English-Russian bilingual street signs (constituting the majority of the town's bilingual signs) were placed in the city centre in 2008 on the occasion of the EU-Russia summit. Soon after the necessary, or least reasonable, placement of these bilingual signs, a similar tendency appeared in the cultural sphere, especially in the case of museum collections since the first half of the 2010s, although the English section of these descriptions is not a complete translation of the Russian text but often consists only of the mere denomination of the displayed artefacts. Words or phrases in English (written in the Latin or Cyrillic alphabet) occur in advertisements targeted at Russian-speaking customers as well. The main loci of English logos and other brand-building expressions written in Cyrillic are restaurants of international fast food chains, appearing in Khanty-Mansiysk one after another. Although the first language of commercials and advertisements, just as of the customers, is Russian, a growing number of signs display the nature of the offered services in English as well, e.g. at language schools and local fast food restaurants. 


\subsubsection{Other languages present and absent}

Besides the signs containing texts in Russian, English or the Ob-Ugric languages, the remaining examples are to be found written in only three European languages, which are Czech, Slovak, and Hungarian. The bilingual signs in these languages and Russian are situated at the honorary consulate of the Czech Republic, Slovakia, and at the entrance of the Hungarian classroom of the Yugra State University, respectively. On the one hand, the presence of these languages is surprising, since no native speaker of them lives in town (except for the visiting lecturer of Czech language at Yugra State University). On the other hand, it is also surprising to compare the presence of the three European languages with the complete absence of signs in minority languages spoken in Russia or the former Soviet Union. Both the indigenous and local languages (e.g. Nenets or Komi) spoken in the Okrug and the neighbouring subjects, as well as the languages of immigrant ethnic groups, are missing from the linguistic landscape of KhantyMansiysk.

6.3. Ob-Ugric languages in the linguistic landscape of Khanty-Mansiysk

6.3.1. Ob-Ugric languages in the physical sphere

The signs on the buildings of institutions, communal places, stores, memorials and other sites related to Ob-Ugric people in Khanty-Mansiysk are dominantly written exclusively in Russian. There are only a few documented exceptions, usually in the business sphere, for example, the names of the cinema and leisure centre Langal and hotel Misne. While the name of hotel Misne is rarely commented on in everyday conversation as a reference on the relatively well-known, fairy-like Mansi mythological figure, the name of the cinema centre Langal is often remembered to have got its name after "the Khanty name" of the river Irtysh. ${ }^{28}$

Just as in the case of language use, while observing the linguistic landscape the less official domains seem to be more promising for minority language use than the official or

\footnotetext{
${ }^{28}$ In fact, Лауал is the name of the river Irtysh in the Kazym Khanty dialect, which is the variety with the highest prestige and highest number of speakers in Khanty-Manisysk.
} 
business spheres. Since the two most dominant domains of Ob-Ugric language use - family and education - are not equally active and significant in the linguistic landscape, it is reasonable to pay more concentrated attention on the role of education. In Khanty-Mansiysk no public school offers language classes in Mansi or Khanty, the only educational institution offering Mansi and Khanty lessons is the alternative educational centre Lylyng Soyum. The name of the Centre contains Mansi words (льлльу сорюм 'living creek'), thus, the sign bearing the name of the Centre at the main entrance of the building is the only sign in Khanty-Mansiysk that functions as a marker denoting the presence of $\mathrm{Ob}-\mathrm{Ugric}$ language and culture instead of merely referring to the titular peoples of the Okrug as a cultural reference of identity construction. Subsequently the Lylyng Soyum Centre is the most stable place in Khanty-Mansiysk where signs and texts in Ob-Ugric languages are present not only on the outside of the building but also inside. In the classrooms of the Centre both permanent and temporary signs and texts are displayed, and it is important to note that while in the oral language use the overwhelming dominance of Russian is unquestionable, taking the signs into account, texts in Khanty and Mansi outnumber the ones in Russian.

The lack of more a conscious, diverse and prominent presence of the Ob-Ugric languages in public spaces is of course motivated by the non-official status of the Ob-Ugric languages as well as by the small number of Ob-Ugric native speakers in town. Still, it is difficult to explain why, for example, the memorial plates of Yuvan Shestalov, the most wellknown Mansi poet and local public figure, do not feature any Mansi text, since neither the memorial plaque on the house he used to live in, nor his statue in the local open-air museum do so. Overall, the lack of signs containing Ob-Ugric elements as a result of status planning or spontaneous emplacement is rather surprising.

\subsubsection{Visual signs and the Ob-Ugric landscape}

The definitions of linguistic landscape generally cover written elements only, still papers expanding their field of observation to "visual images, non-verbal communication, architecture and the built environment" (e.g. Jaworski and Thurlow 2010: 2, cited in Hornsby and Vigers 2012: 57) can also be found. For a more comprehensive investigation of the presence of Ob-Ugric people in Khanty-Mansiysk it is definitely necessary to include materials 
containing no text but visual elements - as e.g. buildings, statues and graffiti - to the research, in addition to the observation of written signs both in the online and offline domains.

The Khanty-Mansi Autonomous Okrug - Yugra, and its administrative and cultural centre Khanty-Mansiysk often prefer to feature the name Yugra, depictions of rituals, or decorative elements related to the Ob-Ugric peoples on surfaces belonging to governmental institutions, and occasions of municipal, regional importance. Besides representing the indigenous minority peoples of the Okrug, this practice is rather aimed at creating the Okrug's and its capital's unique identity within the Russian Federation (Nagy 2016: 10-11). Buildings resembling the shape of the chum, the traditional dwelling place of the indigenous peoples, can be observed at many sites of Khanty-Mansiysk, especially on prominent spots of the city centre, as for example the mall in the main square of the city, or the main building of one of the largest hotels in town, Yugorskaya dolina. Khanty-Mansiysk is surprisingly rich in monuments and sculptures, and there are several interesting statues related to the Ob-Ugric religious beliefs and myths as well. The statue titled "Hunter and bear", erected in 2005 next to the municipal anthropological museum, the Museum of the Human and Nature, depicts a realistic yet highly supernatural fight of the Ob-Ugric hunter and the bear, a beast deeply venerated and surrounded by many taboos in the Ob-Ugric traditions. In 2010 seven statues have been placed along Dzerzhinsky prospect illustrating Ob-Ugric mythological figures and events, such as the Spirit of Water or the Creation of the World.

With the exception of a few tags, no graffiti were observed in Khanty-Mansiysk, especially in the city centre until 2014. In 2014, on the initiative of a graphic artist and teacher of the local art school, dozens of graffiti appeared in the streets of Khanty-Mansiysk, at the beginning in cooperation with the local government, later in an independent, partly illegal way. The graffiti contain almost no texts or written elements, but many of them are related to cultural elements of the Ob-Ugric peoples. Next to the Museum of the Human and Nature a whole series of graffiti depict the Ob-Ugric world view since the creation of Earth to the visualisation of nomadic lifestyle, which is still followed by a smaller group of the Ob-Ugric peoples. The most spectacular and impressive element of graffiti representing the Ob-Ugric peoples in public spaces is the graffiti of the café Mona Lisa depicting the Mona Lisa of Khanty-Mansiysk against the background of a tundra landscape with an Ob-Ugric tent, while the graffiti is compiled of small squares illustrating aspects of urban life, thus, merging traditions and urban lifestyle in the same picture. 


\subsection{Summary}

Although the majority of the Ob-Ugric peoples have already moved to cities, they form small, fragmented minority groups there, and their presence is visible in the public spaces only to a small extent, even in the cultural and administrative capital bearing their name. The presence of Ob-Ugric languages in the linguistic landscape - just as in the context of language use - is rising, yet it is still rather narrow in Khanty-Mansiysk. Mansi and Khanty are absent from the official and semi-official domains of the linguistic landscape, almost all the available examples of Ob-Ugric elements in the linguistic landscape are to be found in the business sphere and in domains controlled by bottom-up initiatives, such as alternative minority institutions and private language use.

There are a few documented exceptions under the rule of Russian linguistic dominance, usually in the business sphere, mostly in the forms of proper names (e.g. place names). These exceptions function to demonstrate the presence of indigenous minority peoples and do not allude to any actual presence of representatives of the Ob-Ugric peoples in the buildings in question or any minority language use.

The most significant element of the Mansi linguistic landscape and the only representative of the non-business sphere is the alternative educational institution of KhantyMansiysk, the Lylyng Soyum Centre. Besides the sign at the entrance, Mansi and Khanty signs, texts, and decorations are also regularly displayed in the classrooms of the Centre, during both courses and performances.

Private language users seem to have little or no impact on their physical environment, their activity using Ob-Ugric languages in written forms can be observed rather in the online domains than offline. On social media sites indigenous minority languages are also used by individualss with minimal command of Khanty or Mansi who typically publish shorter texts in Ob-Ugric languages.

Visual arts, especially sculptures and graffiti gain preeminent significance in the ObUgric linguistic landscape of Khanty-Mansiysk, and it is also important to mention that while in the case of written elements of the linguistic landscape no outsiders are involved, the 
inventors, initiators and artists participating in the creation of Ob-Ugric visual arts without exception come from non-Ob-Ugric backgrounds.

My findings suggest that Ob-Ugric languages play an important role in the linguistic landscape, and, thus, in the self-identification of Khanty-Mansiysk as a city, but the textual and visual presence of Mansi and Khanty elements in the offline and online publicity of the city is apparently merely symbolic. Although examples may be found of both bottom-up and top-down initiatives of placing signs with Ob-Ugric elements, the Ob-Ugric linguistic landscape lacks any sign of intentional or complex status planning. 


\section{Language acquisition}

7.1. Characterising the Mansi speakers according to age groups

The Mansi speakers in the Khanty-Mansi Autonomous Okrug can be roughly divided into three groups according to the correlation between age and command of the language (similarly to Skribnik and Koshkaryova 2006). The first group, the elderly speakers born before 1945, were born and raised in small Mansi settlements, in the traditional lifestyle, and with very little formal education. These speakers are bilingual to some extent, though their command of Russian is clearly below the native speaker level. Members of the second group, the middleaged generation (born between 1945 and 1975), were also born in Mansi families and raised in traditional Mansi settlements, but these speakers became Mansi-Russian bilinguals during their school years. Many of them have college or university degrees, and they live in urban settlements and in inter-ethnic marriages. The third group, the youngest Mansi speakers born after 1975 only constitute a tiny minority in their generation. As Consultant 3 phrased it:

In the 2000s, these young people rather lived in cities, for them the language, taking speech into consideration, was already lost. [...] [T] hose who grew up after us have learnt this and that from their grandparents, they could understand us, they could even joke, but they could no longer talk. Those attending college after us were only able to learn according to textbooks. Our generation, who still speaks the language well, is already over forty. Those younger than us can't speak any more, regardless of city or village.

Like middle-aged Mansi speakers, the majority of the speakers belonging to the youngest generation have attended Russian-medium schools and during most of their adult life they have been living in urbanised settlements, even if they were born and raised in Mansi settlements and acquired Mansi language in their families.

The oldest generation of speakers has native competence in the Mansi language and has been using Mansi both in childhood and adulthood. As Consultant 63 recalled in order to confirm the latter:

When my cousins studying in upper grades came home in the 1950s and were acting as if they were unable to understand Mansi any more, my grandmother told them that a year 
ago they knew no Russian at all, and if they indeed had forgotten how to speak Mansi, they

didn't need come here anymore.

Speakers belonging to this first group understand Russian and are usually able to converse in it, with an easily recognisable accent and grammar errors. Some representatives of this generation were reported to be multilingual, speaking Komi or Khanty besides Mansi and Russian. The Mansi-speaking middle-aged generation used Mansi only in their childhood, continued to speak it to their elder relatives, childhood friends, and generally shifted to Russian when starting their own family. Though the representatives of this generation often live in an interethnic marriage and report having learnt their spouse's mother tongue as well, in practice they mainly use Russian. Some representatives of the youngest generation, born after 1975, were raised in dominantly or exclusively Mansi speaking families as younger siblings, thus they grow up having Mansi as their mother tongue. ${ }^{29}$ Still, the majority of this age group have not acquired any other language than Russian, and even if they have, they have almost predominantly used Russian during their childhood and are very likely to continue using Russian in their own families as well.

The Mansi speech community of Khanty-Mansiysk may be divided into the same three categories. The group of the oldest speakers has always been of small number and keeps decreasing, consisting of a few Mansi specialists working at the Ob-Ugric Research Institute, the Pedagogical College and the Yugra State University, as well as the elder relatives of the middle-aged Mansis working and living in Khanty-Mansiysk. Some of these elderly speakers have been living permanently in Khanty-Mansiysk, while others prefer to spend only the winter months in the city, and for the summer they return to their home village. The middle-aged speakers have come from all over the Mansi-speaking territories, most of them speak the Sosva and Lyapin varieties, some the $\mathrm{Ob}$, and a few the Lozva varieties and the Konda dialect. They form the largest fraction of the Mansi speakers in Khanty-Mansiysk, about fifty people, mostly women. The youngest Mansi speakers in Khanty-Mansiysk are usually not directly related to the middle-aged speakers and were not born and raised in the city either, most of them come

\footnotetext{
${ }^{29}$ It is important to note that children living in the small Mansi community of the Sverdlovsk Oblast, very likely due to the isolated location of the community, are characterised by speaking Mansi as their mother tongue.
} 
from the Lyapin-region, and some from the Lozva. No speaker is known to have acquired the Mansi language while living in Khanty-Mansiysk.

\subsection{Intergenerational language transmission}

The speakers born before 1945 were raised in Mansi-speaking families, in most of the cases in monolingual Mansi, or at least non-Russian-dominant villages. They got into contact with the Russian language through the school system, but since the generation's education was intermitted by the war and the consequent economic downturn, and the eldest speakers stayed in contact with the Mansi villages during their work years as well, and their Russian competence never became as high as their Mansi proficiency. The oldest speakers have spent their whole life in Mansi-speaking households, acquired Mansi from their closest relatives and raised their children speaking Mansi as well.

The speakers of the middle-aged generation grew up in Mansi-speaking families, acquired the Mansi language there, and used it as the medium of conversation within their family and micro-community. When asking Consultant 22 about her language acquisition history, she expressed her close relationship with the Mansi language as follows:

CsH: How have you acquires the Mansi language?

Consultant 22: Mansi?

CsH: Yes.

Consultant 22: I've acquired Russian. Mansi-I grew up in it.

As students, middle-aged speakers spoke Mansi with their Mansi peers at school and in dormitories, despite of the controversial minority language policy adapted at public education: Mansi was the medium of education in primary school classes (especially during the preparatory year) and a subject afterwards, also many of the teachers at primary classes were Mansis themselves, yet, students speaking Mansi outside designated classes were often punished, a common practice in the education of indigenous minority children of the North 
(Bartels and Bartels 1995: 56). The representatives of the middle-aged speaking group came into contact with the Russian language usually at school and became balanced Mansi-Russian bilinguals by the end of their studies. Due to the insults suffered at school and the generally low prestige of the Mansi language, middle-aged people usually did not transmit the Mansi language to their children, or did not force its use in case their children decided to give up speaking it. As a result of this practice, the tendencies of intergenerational language transmission radically changed by the 1980 s and '90s.

Mansi families do not form neighbourhoods or groups living in Khanty-Mansiysk, the cohabitation of three generations in one household is also rare, and shared ethnic background, home region or similar language skills do not appear as community-forming factors either, thus, for the majority of Mansi children living in Khanty-Mansiysk the nuclear family provides the only possibility to acquire the Mansi language. But Mansi children and young adults born or raised in Khanty-Mansiysk mostly grow up in inter-ethnic families and in multicultural environments, where Russian is the dominant or exclusive language of communication.

According to Spodina's small-scale study carried out among university students of indigenous minority background, a remarkably high proportion of indigenous students in the Khanty-Mansi Autonomous Okrug are Russian monolingual, yet the prestige of the Mansi language is slowly but significantly growing, and even those people claim it to be their native language who do not speak it at all (Сподина 2011: 214).

The factors causing the interruption in intergenerational transmission can be observed in the independent adult life of middle-aged speakers. These factors are largely due to urbanisation, since the three main variables controlling language choice and thus affecting language transmission are the place of residence, profession, and marriage. Middle-aged speakers are living in urban(ised) type of settlements of more than a few dozen inhabitants, that is, in large villages, towns, and cities. They have occupations other than traditional fishing, hunting, or reindeer-breeding, which means that the professional terminology they use during their work is Russian. With some exceptions, they work together with people who are usually unable to communicate in Mansi. In settlements inhabited by both indigenous and immigrant ethnic groups, the majority of inter-ethnic marriages are between indigenous ethnic groups and other ethnicities (Демографические процессы 2013). As the result of these three factors, middle-aged Mansi speakers use Russian in almost every sphere of their lives, and they are unable to create a Mansi-speaking environment where they could teach Mansi to their children. 
The heritage language speakers living in Khanty-Mansiysk typically are the children of the middle-aged Mansi speakers living in Khanty-Mansiysk. The first cohort of heritage language learners demanding Mansi language courses in Khanty-Mansiysk, and participating in self-education or the available local Mansi programs also used to come from the children of middle-aged speakers, and they still form the majority of students attending these courses.

\subsection{Language acquisition through education}

The Mansi language has both standardised variety and codified written form. Literacy in the Mansi language has a relatively short history. Although Mansi texts were published in Tsarist Russia already at the turn of the $19^{\text {th }}$ and $20^{\text {th }}$ centuries (Эпископ Никанор 1903), their subject matter, language and distribution made them practically inefficient for the speech community, and they primarily hold importance for scholars. One of the best known examples was the Gospel of Matthew translated to the Konda dialect, first published in 1869, arriving in Hungary via Helsinki and Tartu, where, besides Reguly's unexplained notes, it was the only source of knowledge regarding the Mansi language for decades (Hunfalvy 1872: 1, Матпіинэл и Маркнэл... 1882,).

The actual beginning of Mansi literacy is considered to have begun in the year 1931 (Чернецов 1937: 168), when the Latin based alphabet of the Mansi language was created in Leningrad, at the Institute of the Peoples of the North, together with the writing systems of other Siberian languages. The transition to Cyrillic writing system took place in 1937, in accordance with the provisions of policy of standardisation. The first books in Mansi were the Mansi translation of Jakobson's book on Arctic animals (Jakobson 1935), Vladimir Tambi's work on the history of aviation (Tambi 1937), Pushkin's tale of fish and the fisherman (1938), and Maxim Gorky's biography (Торгашин 1940). The first textbooks (Śernecov 1932, 1934) and dictionaries (Чернецов and Чернецова 1936) used in public education were published at around the same time. (For more information on Mansi literacy, see section 9.4.)

As opposed to the problems surrounding the standardisation of the Khanty language, unsolved and re-emerging to this day (see, e.g., Schmidt 2006: 19-36, and Sipos 2006), the creation of the literary Mansi standard was seemingly spared these difficulties. Works of fiction, 
textbooks, and other publications were written almost exclusively in the northern dialect, ${ }^{30}$ as the other dialects did not have a significant speaking community left. The Mansi standard was based on the Sosva variety of the Northern dialect.

The social changes that led to the establishment of the system of public education took place in the Mansi territories after the Soviet takeover. In the 1930s, as a result of collectivisation, the majority of the families still following a nomadic or semi-nomadic lifestyle were settled, often in new, centralised settlements. In parallel with the development of the new settlement network, infrastructure was created, followed by the establishment of the school network: primary schools, boarding schools, and secondary vocational institutions operated in the central settlements (Schmidt 2006: 21-22).

Zamyatin (2017) notes that the policy of multiculturalism was neglected in the Soviet Union as early as the late 1930s, and the Russian language, which was originally introduced as a mere compulsory subject, gradually became the medium of instruction. The arrival of the internal immigrants in the Northern regions of Russia between the 1930s and the mid-1950s led to dramatic changes in the lifestyle of indigenous peoples and a rapid shift from indigenous languages to Russian. In 1958, when parents were given the opportunity to choose the languages of instruction in schools, many small national schools switched to Russian, while the introduction of boarding schools distanced and alienated indigenous children from their families and indigenous languages, thus interrupting the continuity of intergenerational language transmission (Zamyatin 2017: 188).

The grammars and textbooks used in state education were almost without exception designed for students who were native speakers of Mansi, preferably raised in families following traditional lifestyles. The schoolbooks generally featured stories and illustrations depicting this traditional lifestyle, that is, they represented an already unfamiliar, distant model for the alienated students. As a result, these schoolbooks were unsuitable to help Mansi children without a Mansi proficiency to acquire the language or to raise the students' interests in and motivation towards the acquisition of Mansi.

The decisionmakers needed a very long time to realise that if they wanted to maintain their image as the authorities motivated to stop Mansi language shift, they needed to revise the regional policy regarding textbooks for indigenous languages. Supposedly it was the impulse

\footnotetext{
${ }^{30}$ Although a small number of Mansi literature written in the Eastern dialect (Конькова 1991) has been published, even in the second half of the 20th century this dialect never played a more important role in education.
} 
of alternative educational institutions (cf. Chapter 10.6) that served as inspiration for creating a new generation of textbooks. First, additional collections of tests were published, to complement the existing textbooks (Нахрачева et al. 2012, Соловар and Кумаева 2012, Герасимова 2015), then starting in 2014 a new generation of experimental Mansi textbooks appeared (Кумаева and Нахрачева 2014а, Кумаева and Нахрачева 2014b, Кумаева and Шиянова 2014а, Кумаева and Шиянова 2014b, Кумаева et al. 2014), especially designed for students without previous competence in Mansi. The textbooks consist of only twenty pages each, and being textbooks for the elementary classes, they contain at least as much visual material as text, accompanied with the collections of tests complementing the new curriculum (Кумаева and Соловар 2015а, Кумаева et al. 2015, Кумаева and Соловар 2015b), they may assist heritage language education both in state supported and alternative educational programs. The textbooks and review exercise books were followed by collections of tests for what is called Olympiads of the Mansi language (Герасимова et al. 2016), and besides the Mansi textbooks, the second Mansi language mathematics textbook appeared (Динисламова 2014).

Publishing next generation Mansi textbooks appears to be an indicator, or at least a playground for a fight of dominance. In no other way is it possible to explain the publishing of two Mansi primers in the same year, one in Saint Petersburg (Афанасьева 2013), the other in Khanty-Mansiysk (Панченко 2013). In 2017 Prosveshenie, the publisher of textbooks in indigenous languages, announced the publication of the first four volumes of a new series of Mansi textbooks under the aegis of the project "New textbooks of the North" (Новая линия...), while based on personal communication further textbooks are made ready for the classes 1 through 9. Upon contacting the publisher, no confirmation or detailed information was provided about the textbooks or their authors.

The efficiency of teaching Mansi to heritage language learners with methods and materials designed for native speakers can be demonstrated with the help of the study carried out among the students of the former Institute of History, Culture and Languages of the Ugric Peoples (i.e. the departments focusing on Ob-Ugric languages and cultures at Yugra State University). According to Spodina's survey among the indigenous minority students of the Institute (that is, students of Mansi, Khanty, and Nenets origin), $70 \%$ of the respondents named an indigenous minority language as their mother tongue, and $20 \%$ of them considered themselves bilingual in Russian and an indigenous minority language. On the other hand, the same respondents stated that they had been using only Russian at home, and $20 \%$ of them came from families where no family member spoke any indigenous language (Сподина 2011: 214). 
This survey illustrates the contradiction of the ideal and the real situation: while the students participating in Mansi language education are supposed to and are officially believed to have native or very high competence in Mansi, most of them have practically no or only very unstable knowledge of Mansi.

The effects of the new point of view regarding the teaching indigenous languages of the Khanty-Mansi Autonomous Okrug as well as the new generation textbooks appearing as the results of this change may not be immediately visible and most likely need to be aided by new teaching methods, and possibly newly trained or re-trained teachers as well.

Due to the problems of intergenerational language transmission, language teaching could play a key role in maintaining language acquisition. At the time of the foundation of public education for the Mansi, the goal of the Mansi language in education was to direct Mansispeaking students from the use of Mansi to the Russian language through a transitional model. During the last decades the situation has changed: there are practically no students who are unable to speak Russian by the time they reach school age, thus the purpose of Mansi language education has also changed, and its primary task today would be to deepen the children's Mansi proficiency and to help them learn the language if they had no opportunity to acquire it at home. However, public education in its current form, despite all intentions, is unsuitable for teaching the language without prior language skills, mostly because of the unchanged teaching methods and textbooks, whose target audience consists of native speakers and excludes heritage learners or second language learners.

\subsection{Summary}

The Mansi speakers living in Khanty-Mansiysk may be categorised according to the correlation of their age and command of the Mansi language. There have been a few old speakers born before 1945 living in the city. They were without any exception born in the countryside, into Mansi families, and they were raised as Mansi native speakers and have been solely or dominantly speaking Mansi thorough their life. They became the temporary or permanent citizens of Khanty-Mansiysk as invited specialists working for one of the Ob-Ugric institutions (for the list of institutions, see section 5.2.2), elderly relatives of middle-aged speakers living in Khanty-Mansiysk, in order to help their relatives or because of becoming 
unable to lead an independent life. The middle-aged speakers of Khanty-Mansiysk were born between 1945 and 1975, also in the countryside, and into Mansi families. Mansi is the dominant or only language they have been using with their close relatives and the language they used in their immediate environment. The representatives of the youngest group of speakers, born after 1975, were typically born and raised in similar families, but usually in larger type of settlements and in multiethnic communities using Russian as the language of communication. Although the middle-aged speakers' children are also living in Khanty-Mansiysk, they are heritage language speakers and to a lesser extent heritage language learners, while the young speakers are not or only distantly related to the middle-aged speakers. Thus, the Mansi speakers of KhantyMansiysk represent a different level of language endangerment, definitely endangered according to the UNESCO classification, and threatened according to the EGIDS classification.

Besides possible private considerations, the interruption of the intergenerational transmission is largely affected by urbanisation. The Mansi represent a small proportion of the population of Khanty-Mansiysk, forming no neighbourhood or microcommunity in town, and often living in dominantly Russian-speaking interethnic marriages. Mansi language education cannot expect students to have a previous competence or knowledge of the Mansi language from the students, and it is unable to solve the problem of language transmission. Even though the specialists in charge recognised the problem and decided to organise the publication of Mansi textbooks, the new generation of textbooks could not compensate for the lack of intergenerational language transmission. (The relation of Mansi language education and language use is discussed in section 9.6 below.) 
8. Urban Mansi language use

8.1. The Mansi varieties spoken in Khanty-Mansiysk

The classification of the Mansi varieties into dialect groups could not take place until researchers have collected a sufficient amount of linguistic material to categorise them, that is, until the second half of the $19^{\text {th }}$ century. Early Hungarian researcher Bernát Munkácsi's first classification, for example, divided the Mansi language into two major sub-groups, the Northern dialect group (spoken by the Upper Lozva river, the Sosva, and its tributaries) and the Southern dialect group (the Konda, the Pelym and the Middle and Lower Lozva varieties) (Munkácsi 1894: 1). Later a more differentiated classification became widely used in the Western and Russian literature ${ }^{31}$ (e.g. Riese 2001: 7, Kálmán 1976: 10-11, Ромбандеева Вахрушева 1984: 3) as well, dividing Mansi into four different dialect groups (Northern, Western, Eastern, and Southern).

The Western dialect group consisted of the varieties formerly spoken along the Middle and Lower Lozva, as well as along the Vagilsk and Pelymka rivers, in which group Russian and Komi influence was significant. The Eastern dialects of the Mansi language have been spoken along the Konda and Yukonda rivers, with considerable Tatar influence recognised in them. The varieties of the Southern Mansi dialect group were spoken along the Tavda river. The strongest Tatar influence appeared in these varieties (cf. Keresztes 1998).

The Southern dialects were extinct by the $1950 \mathrm{~s}$, the Western dialects died out somewhat later. The situation of the Eastern Mansi dialects is uncertain, most researchers believe that Eastern Mansi is almost or completely extinct by now, while some fieldworkers have claimed that there may still be a handful of isolated speakers. ${ }^{32}$ The remaining Mansi speakers are almost

\footnotetext{
${ }^{31}$ Except for Honti, who distinguished three dialect groups in Mansi, the Northern, the Central and the Southern groups, and divided the Central group into two further sub-groups, the Eastern (spoken along the Konda and Yukonda rivers) and the Western (spoken by the Pelymka, the Vagilsk rivers, as well as along the Middle and Lower Lozva) (Honti 1988: 148).

32 Szilágyi (personal communication, 2018) reported meeting at least two speakers of Eastern Mansi: Maksim Semenovich Shivtorov in Shugur, and Gavril Andreevich Vakhrushev in Polovinka. Although the online newspaper Khanty-Mansi Mir sadly announced the obituary of G. A. Vakhrushev (Светлой памяти, Герой), nо similar news has been published of M. S. Shivtorov (LS 2015/15, p. 14).
} 
exclusively using the Northern dialects, thus, unless specifically noted, this dissertation identifies the Mansi language with the Northern Mansi dialect.

According to this widely prevalent classification, the Northern Mansi dialect group contains the dialects spoken along the Sosva and the Lyapin rivers, formerly along the Upper Lozva, and in the Berezovo region as well. This dialect group (especially the Sosva variety) serves as the basis of standardised Mansi. The Northern dialect group is characterised by Russian, Komi and Nenets influence, and has been in intense contact with the northern Khanty dialect as well (Keresztes 1998: 390).

In Khanty-Mansiysk, only the speakers of the Northern Mansi dialect group have been identified, most of them speak the Sosva and Lyapin varieties, a few speakers grew up by the $\mathrm{Ob}$ river, and some other speakers come from the Sverdlovsk Oblast. The speakers of each variety agree with the general claim in the literature (e.g. Kálmán 1976: 10) that the varieties of the Northern dialect are mutually intelligible.

\subsection{Language status}

Regarding the status of the language, Mansi is an indigenous minority language spoken in Western Siberia. Mansi is not an official language, either at the regional or the municipal level. According to Act N 89-03, passed on 4th December, 2001, by the Duma of the KhantyMansi Autonomous Okrug, the authorities of the Okrug provide a social, economic, and legal protection of the languages of indigenous peoples living in the Autonomous Okrug. According to Article 2 of the act, the authorities of the Okrug are obliged to preserve, study, and develop the languages of indigenous peoples; to develop, adopt and implement measures and programs aimed at the conservation; and study and develop the languages of indigenous peoples, including:

(a) the development of measures to enhance the role of indigenous languages;

(b) the development of measures to use the languages of indigenous peoples in public life, the gradual expansion of their social and cultural functions;

(c) the development of measures aimed at promoting the languages of indigenous peoples and their culture in the media; 
(d) conducting research to expand and deepen the development of indigenous languages;

(e) providing appropriate material and technical support to educational institutions providing instruction in the native languages of indigenous peoples;

(f) the preparation and publication of training programs, textbooks, teaching aids and dictionaries;

(g) the introduction of a system of lifelong learning of mother tongues in relevant educational institutions;

(h) improving the system of training teachers for teaching the languages of indigenous peoples in schools, secondary and higher education institutions;

(i) assisting the study of the languages of indigenous peoples living in the Autonomous Okrug on the basis of inter-regional treaties and agreements with constituent entities of the Russian Federation;

(j) promoting the development of linguistic contacts and ties of indigenous minorities with related Finno-Ugric peoples. (Act N 89-03)

Mansi is not used as the language of jurisdiction, and no laws, regulations and administrative provisions are published in Mansi, except for the Universal Declaration of Human Rights (Resolution 217 A (III) and the UN's Declaration on the Rights of Indigenous Peoples (Resolution 61/29). Short summaries of the regional directives in Mansi are regularly published in the Mansi newspaper Luima Seripos. The Mansi language is also absent from public transport and official public signage.

Mansi has an extremely limited economic significance. It plays a marginal role in the business sphere or the labour market. Speaking or understanding Mansi does not provide any advantage in working positions unconnected to the Mansi language or culture, moreover, due to the insufficient number of Mansi speakers even positions closely related to the Mansi language may be occupied by people with inadequate proficiency in Mansi, especially in the field of education and scholarly research. 
8.3. Non-linguistic conditions affecting Mansi language use

The use of the Mansi language is closely connected to the speakers' Mansi proficiency, while proficiency in Mansi is typically related to the speakers' age. It is a common experience that the older the speakers are, the more likely they are to have native competence in Mansi. This general tendency is often counterbalanced by the speaker's place of birth and residence: younger speakers born and raised in smaller, monolingual Mansi settlements often have good command of the Mansi language.

In the case of bilingual speakers, language choice may be influenced by multiple causes. According to Grosjean, factors determining language choice may be the participants, the situation, the topic of discourse, and the function of interaction (Grosjean 1984: 135-143).

In private conversations respondents stated that they use Mansi with their relatives and childhood friends no younger than them, without any further specification of the situation or the topic. When referring to the topics of discussion, the consultants mentioned no preference, they stated that they could converse about any kind of topic. Although while answering another researcher's questionnaire, to appoint the persons whom they would use only Mansi, Consultant 3 mentioned the Mansi gods and spirits. This statement emphasises the role of religion as the only domain of language use in which only Mansi-speaking actors may be engaged and only the Mansi language may be used. (For a detailed description of Mansi religious life in KhantyMansiysk, see section 9.12.) Perhaps in connection with religious practices and ritual taboos, the Mansi prefer to use Mansi when speaking or writing about various illnesses and their treatments, certain crimes, and family secrets, often of a sexual nature.

Young Mansi speakers are often described as too timid to use Mansi in public. Consultant 42 reported the following:

Youngsters are always shy. There used to be classes [at the department of Mansi philology of the Yugra State University] with rather good Mansi speakers. We were travelling together on the marshrutka [shared routed taxicab, the most popular vehicle of KhantyMansiysk public transport], I asked them questions in Mansi, and they answered me, but they were giggling all the time. After we got out of the car, I asked them how it felt. "Well, it was awkward. What are they [probably fellow-passengers] going to think about us?" "Do you hear others, Tajiks, Uzbeks speak their own language among themselves?" "Yes." "And do you find it shameful?" "No, on the contrary, we keep listening to it, we find it 
interesting." "This is the same." Their mentality is like that, they are quiet, they are shy.

They speak even Russian quietly.

Although Consultant 42 draws a clear line between the generations, this grouping may under- or overgeneralise, since on hand representatives of the same generation have - although sporadically - been witnessed to use Mansi in public transport, on the other hand not only young speakers, but also the middle-aged speakers in general prefer switching to Russian when they have unfamiliar people within earshot.

It is a general tendency that Mansi speakers only use Mansi if they know their conversation partners relatively well, i.e. if they have an idea about each other's competence in Mansi, if they have a common history of using Mansi, and only when no third person without sufficient knowledge of Mansi is within hearing range (in order to avoid confronting outsiders with an unintelligible language). This practice can be linked to the offences which today's Mansi speakers have suffered during their childhood in boarding schools because of using their mother tongue instead of Russian, and with the relatively low prestige Mansi has had until recently.

\subsection{Domains of language use}

Mansi is an endangered language which plays a minor role in its Russian-dominated, multi-ethnic and multilingual environment. Its situation is heavily affected by the loss of the traditional way of life and by rapid urbanisation. The domains of Mansi language use are expanding but still limited.

As it has already been mentioned, Mansi is barely present in official or semi-official domains such as legislation, public transport or street signage, and due to its low economic significance, it is also absent from the business sphere and only plays a marginal role on the labour market. While in other parts of the Khanty-Mansi Autonomous Okrug firms with Mansi names operate, ${ }^{33}$ in Khanty-Mansiysk the value of the Mansi language as a brand seems to be somewhat lower, in contrast with the Khanty language as such, no Mansi tags have ever

\footnotetext{
${ }^{33}$ As for example ООО «Элаль» in Saranpaul. (https://www.list-org.com/company/1829720)
} 
appeared even on a fish can. Besides the complete lack of a written presence, the oral use of Mansi is missing from the everyday use of official and semi-official domains as well.

The Mansi language has a relatively short history of literacy, Mansi publications come in a relatively narrow range of genres. Mansi is practically limited to scientific publications, especially various kinds of folklore collections (e.g. Попова 2001 or Попова - Ромбандеева 2010) and occasional short papers (е.g. Ромбандеева 2004, Динисламова 2015). While Khanty infrequently has been used to perform scientific presentations at conferences of local importance in Khanty-Mansiysk, no similar practice has been witnessed with Mansi as the language used at work. During Soviet times, a small number of children's books appeared in Mansi translation (е.g. Гайдар 1955, Маяковский 1955), this tradition was not continued after the change of regime, with the exception of folk tales (e.g. Слинкина 2013) being published, which differ from the folklore collections only in their length and illustrations. Similarly to book publishing, Mansi is absent from audio and video materials as well, there are no Mansi audio books, Mansi cartoons, or Mansi-speaking films.

There is no unofficial public domain of Mansi language in Khanty-Mansiysk which would be unconnected to family gatherings, and which lone Mansi speakers or individual Mansi language learners could attend. Consultant 29 reported on a previously existing domain at the local art centre, where the Mansi of Khanty-Mansiysk used to gather every weekend to have a club of Mansi conversation.

Compared to the public domains, Mansi has stronger position in family life and in education; it also has a small but growing importance in leisure activities, such as theatre plays and musical performances; and it is present in the online sphere as well. Despite the long tradition of translating the Gospels and other biblical texts into Mansi (Иванова 2000), the language is never used in Orthodox (or other Christian) church services but only in the traditional Mansi religious rituals. The description of the significance and function of these more active domains of language use is presented in the following sections.

\subsection{The Mansi language at home}

Consultants have been very positive about their attitudes to Mansi language use in their families. Middle-aged Mansis stated that they taught their spouses Mansi and raised their 
children (at least) bilingual in Mansi and Russian. Consultant 42, for example, described the language acquisition history of her family as follows:

I've learnt Tatar in order to communicate with my in-laws. We have two children, their first language is Russian, but their second language is Tatar. They used to spend summers in [name of a middle-sized Mansi village] and learned Mansi on a conversational level there.

Participant observation on the other hand found little proof of multilingual inter-ethnic families or bilingual children in Khanty-Mansiysk featuring Mansi language use in addition to Russian and other minority languages. The fact that the children raised by middle-aged speakers participate in Mansi language learning programs as heritage language learners or second language learners proves that they must have had little opportunity to acquire the Mansi language at home.

The use of Mansi as the language of family conversations, just like having a strong competence in Mansi in general, is often associated with having a Mansi parent living in the family (e.g. Fejes 2010: 192). Participant observation confirms attitudes and self-reported practices: Mansi is really used at home in the few families of Khanty-Mansiysk where older relatives live together with their children, just as in the case of Consultants 1,13 , and 16. These older relatives (generally grandfathers and grandmothers) use Mansi on every occasion, they carry out conversations, comment on TV-programs, and make toasts in Mansi, while Consultant 1 even took the opportunity to do an interview with me in Mansi.

The middle-aged Mansi speakers in Khanty-Mansiysk use Mansi with their parents or siblings, if they live in the same household or in the same city, otherwise they correspond with them in Mansi (in emails and text messages). Those middle-aged Mansi-speaking consultants who had no immediate relatives living in Khanty-Mansiysk eventually moved back to their home regions during the duration of observation, such as Consultants 71 and 103.

There are no Mansi speakers among the children born and raised in the Mansi families of Khanty-Mansiysk. Consultant 2's younger child and Consultant 23's older child (both born in 2013) were observed to understand and to a limited extent speak the Mansi language in 2015, Consultant 2's smaller child later gave up using Mansi, while Consultant 23 decided to leave 
Khanty-Mansiysk, thus no further information is available on their child's further language use. Young adults moving to Khanty-Mansiysk in order to study there usually had no one in town to speak Mansi with, as a rule they left the city after a couple of years, such as Consultants 103 and 75. Young adults moving to Khanty-Mansiysk in order to work there usually arrived with their siblings and used Mansi with them, such as Consultants 59 and 60. The only young adult who had no previous knowledge of Mansi but gained proficiency in Khanty-Mansiysk arrived from the Konda region and studied Northern Mansi.

\subsection{Education}

Most of the Mansi population now live in towns and cities, and the children are growing up in multiethnic families in which Russian is the language of interaction. Since the family cannot provide a stable basis for language acquisition and language use, only education could play an important role in increasing Mansi competence, or even in reversing language shift.

Although one quarter of the Mansi children attend schools in cities, there are no urban schools teaching Mansi as a native language (Арефьев 2018: 194). In the territory of the Khanty-Mansi Autonomous Okrug ten primary schools offer Mansi language classes at present. Eight of them are found in the Berezovskiy and Beloyarskiy Rayons (in the towns and villages of Kimkyasuy, Lombovozh, Nizhnie Narykary, Nyaksimvol, Saranpaul, Sosva, Shchekurya and Vanzetur), one in the Kondinskiy Rayon (in the village of Shugur), and one in the Nizhnevartovskiy Rayon (in the village of Sosnoviy bor) (Шесталова 2011, 2012). The students studying Mansi as a subject usually learn it from first to ninth grade (Арефьев 2018: 195).

While Hungarian researchers were given information about only two students learning Mansi in 1990 (and none in 1992) in Saranpaul, the heart of the traditional Mansi-speaking area (Sipőcz and Dolovai 2001: 57), Lalaeva reported 1,042 students in the whole Okrug at the beginning of the new millennium (Лалаева 2005: 3, also quoted in Pusztay 2006: 150-151). The available data on the number of Mansi students for other schoolyears are summarised in Table 10. 


\begin{tabular}{|l|r|l|l|}
\hline Schoolyear & Mansi students & $\begin{array}{l}\text { Mansi students studying } \\
\text { Mansi as a subject }\end{array}$ & $\begin{array}{l}\text { Mansi students studying Mansi } \\
\text { in extracurricular form }\end{array}$ \\
\hline $1996 / 97$ & 1,403 & 436 & 97 \\
\hline $2001 / 02$ & 1,332 & 617 & 0 \\
\hline $2005 / 06$ & 1,463 & 611 & 2 \\
\hline $2006 / 07$ & 1,335 & 524 & 2 \\
\hline $2007 / 08$ & 1,342 & 656 & 0 \\
\hline $2008 / 09$ & 1,362 & 592 & 22 \\
\hline $2009 / 10$ & 1,338 & 355 & \\
\hline
\end{tabular}

Table 10. The number of Mansi students, Mansi students studying Mansi as a subject, and Mansi students studying Mansi in extracurricular form according to school years (based on Арефьев 2018: 453-454)

The Department of Education and Youth Policy of the Khanty-Mansi Autonomous Okrug published more recent statistics; according to their data, in 2011 a total of 453, in 2012 423 school children were learning the Mansi language (Шесталова 2011, 2012). In regional distribution, $0 \%$ of the Mansi children were studying Mansi in the Beloyarskiy and the Nizhnevartovskiy Rayons ( 0 of 23 and 13 Mansi children respectively), only 2.8\% (25 of 771) of the Mansi children attended Mansi as mother tongue classes in the Kondinskiy Rayon, while $49.1 \%$ (320 of the 625 ) of the Mansi children in the Berezovskiy Rayon, and 64.8\% (59 of 91) in the Oktyabrskiy Rayon were studying Mansi during the 2012/2013 school year (Арефьев 2018: 199).

In the territory of the Khanty-Mansi Autonomous Okrug both state-owned and alternative educational institutions try to cope with the insufficient number of well-trained teachers and suitable textbooks. Although, for example, Consultant 63, a respected speaker and specialist described teachers being "roughly speaking semi-literate" in Mansi until recently apparently, the lack of the latter is perceived as the worst problem.

The complex and controversial picture of Mansi education in the Khanty-Mansi Autonomous Okrug can be illustrated best through the example of Khanty-Mansiysk city, the capital of the Okrug. There are 1,208 Mansi people living in Khanty-Mansiysk, on the one hand making them one of the smaller minorities of the city (comprising only $1.51 \%$ of the population), on the other hand, constituting almost one-tenth $(9.85 \%)$ of the total Mansi population in the Russian Federation. 
The situation of public education teaching of the Mansi language in Khanty-Mansiysk is more limited than in the Khanty-Mansi Autonomous District in general. Altogether 238 Mansi children were pursuing their studies in Khanty-Mansiysk in 2010, yet there is no kindergarten, primary or vocational school offering full training or at least some of the classes with Mansi as the language of instruction, also except for a few experimental occasions, Mansi was not taught at any of the local governmental schools either. Mansi language teacher training has been available at the Pedagogical College in Khanty-Mansiysk since its opening in 1932, and in 2002 Yugra State University was founded, where a department of Mansi studies and specialisation of Mansi philology operated. In 2005, the university had 236 Mansi students (Szalontai-Dmitrijev 2005: 20), most of whom attended the program of the department of Mansi studies, despite the fact that students usually entered the university with elementary Mansi language skills and did not reach the conversation level or higher proficiency until graduation (Horváth 2010a: 18-19). In the academic year of 2006/2007, the students studying at the department of Mansi studies, almost exclusively of Mansi background, attended classes in five grades, in groups of 25-30 people, divided into subgroups based on ethnographic and linguistic profiles. This was the last academic year when Yugra State University enrolled students to study Mansi, and in 2010, the institute hosting Mansi studies, among others, was temporarily closed (Сподина 2011: 220). Since then the Mansi language has only been included in the curriculum as an optional subject studied for a short period of time.

\subsection{Mansi press}

\subsubsection{The history of Mansi press}

Mansi articles appeared occasionally during Soviet times, frequently during the $1980 \mathrm{~s}$ in the mainly Khanty-speaking local newspaper of the time, the Ленин пант хува ('On Lenin's way'), but as Consultant 27 recalled, the history of the official Mansi press began due to a coincidence, since as the result of an epidemic, all the Khanty co-workers were lying in bed with the flu, and only one Mansi journalist was able to work, so she compiled a whole number in Mansi. The official Mansi newspaper started to appear in February 1989, under the name Лўима̄ сэ̄рunoc (Luima Seripos, 'northern dawn') twice a month on four pages, now it is available every second week on 16 pages. The print version of the newspaper is in Mansi only, 
while on the official homepage articles can be found in Mansi and in Russian as well. The Mansi texts published cover various topics such as traditional lifestyle, folklore and short biographies, as well as aspects of urban life. Since the newspaper is financed by governmental sponsorship, the laws and decrees issued in the Okrug have to be published in Luima Seripos as well, thus encouraging the journalists to create the missing Mansi (first and foremost, judiciary) terminology.

In addition to Luima Seripos, the editorial board also published five issues of a journal for children, under the title Хо̆талкве ('little Sun'). Another monthly journal for children, Bumcam ('waterdrop') has been published since 2014, written by the Mansi poet Svetlana Dinislamova and edited by Mansi journalist Tamara Merova.

\subsubsection{Vitsam}

The first three issues of the children's journal Vitsam appeared in 2012 (Динисламова 2017: 3), titled Витсам, Раквсам and Туйтсам ('waterdrop', 'raindrop' and 'snowflake' in Mansi). Since 2014 it has been published once a month, on twenty pages, and - according to its imprint - in 999 copies. The journal does not accept subscriptions and is not available online. The production of Vitsam was the Mansi poet Svetlana Dinislamova's idea, she has been responsible for applying for grants to ensure the necessary financial background, and, apart from the few occasions indicated, it is reasonable to assume that all the texts, especially the poems appearing in the journal are Dinislamova's own work. In addition to Dinislamova as general editor, Tamara Merova fulfils the editor's role, and occasionally other Mansi journalists and researchers take part in the writing process.

The name "Vitsam" means 'waterdrop' in Mansi, thus nicely coincides with the similarly titled first book of poems by Dinislamova (Динисламова 2004) and Norova's Mansi primer (Норова 2011), used at the beginners' Mansi courses at Lylyng Soyum Centre. Every issue features a greeting from a Mansi person, a reader's letter from a Mansi child, various educational materials (e.g. on forest animals, Finno-Ugric peoples) published in earlier volumes, puzzles (grammatical exercises, composition booklets), wordlists, riddles, and recipes. 
Mansi folktales, due to their frequent depiction of violent events, are hardly suitable to entertain children, and since besides the occasional, project-based creation of Mansi comics and cartoons no visual program is created for children in Mansi, Vitsam serves as the only regular content intended for children in the Mansi language. The journal is distributed for free, and the undistributed copies are usually stored at the Lylyng Soyum Centre.

\subsubsection{Luima Seripos}

In 1989 Luima Seripos appeared every second week, on two pages, in 130 copies. One newspaper cost one kopek. ${ }^{34}$ The newspapers were written entirely in Mansi, with the traditional orthography characteristic of the time, that is, Cyrillic alphabet without marking vowel length or using letters absent from the Russian alphabet. In 2019 Luima Seripos also appeared twice a month, but this time on 16 pages, in 1,710 copies. The editorial board accepts subscriptions, but the newspaper cannot be obtained commercially. The articles are written in Mansi, with occasional Russian translations of reader's letters in the section for children. The journalists use an orthography which marks the length of the vowels as well as special characters missing from standard Russian, which differs slightly from the orthography used in scientific and scholarly literature. One of the greatest differences between the first and the latest volumes of the Mansi newspaper is the appearance of boxes with headings. The various articles

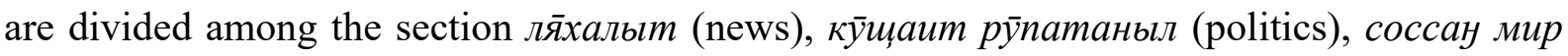
олупса (the life of the Arctic peoples), руттыг оллнэ мирыт (news from the Finno-Ugric world), ловиньтым-уищлахтэ̄н (literary pages), and нйврамыт матгсыл (pages for children) (see also Bíró and Sipőcz 2017).

Currently the situation of newspaper is nearly unsustainable. One of the greatest problems is the overload of the journalists, who receive constant demands regarding the topics and the actual content of the newspaper from the local authorities, and who, besides creating the Mansi articles, are obliged to translate all their texts into Russian as well. As the majority of the editorial board is approaching retirement age, the journalists find it difficult to find or train their successors, since the job is unpopular due to the overwork and the relatively low income, also, among younger Mansis, the lack of sufficient proficiency in Mansi. In spite of its

\footnotetext{
${ }^{34}$ The Soviet average salary in 1989 was 263 rubles per month.
} 
uncertain future, Luima Seripos may be regarded successful in having increased its size eight fold, having become technically and structurally developed enough to meet contemporary standards. The Mansi journalists are successful in formulating local and global news in Mansi, focusing on both rural- and urban-dwelling Mansis, while through their Russian translations they represent the Mansi news accessible to the Russian-speaking readers as well.

\subsubsection{Journalists}

The Mansi newspaper is edited by a relatively small editorial board, which usually consists of 6-8 Mansi journalists. Women are overrepresented among them: during the history of Luima Seripos no more than five men have ever worked for the newspaper as journalists. The journalists were born in villages or other small settlement on the outskirts of the Okrug, in Mansi families, growing up speaking Mansi as their mother tongue and being balanced MansiRussian bilinguals.

Luima Seripos has always been written and edited by a small number of specialists. In 1989 the Mansi newspaper had only five resident journalists, together with about 10-15 correspondents. The journalists were all born and raised in traditional, monolingual Mansi settlements, at least two of them also had university degrees, and after giving up journalism they returned to their previous scientific work.

Recently there are six resident journalists working for Luima Seripos. (Looking through the issues, the reader may find ten recurring family names under the articles, since the journalists tend to use other pen names besides their actual family name as well.) The journalists were born and raised in monolingual Mansi families but spent their schooldays in a bilingual environment, becoming fluent in both Russian and Mansi. Although most of the journalists hold degrees in teaching or the humanities, the editorial board of the newspaper has been their first or most stable workplace.

Besides translating political declarations, travelling to other towns and villages to cover stories, writing their own reports and translating every article into Russian, the journalists also maintain regular contact with the readers. They frequently mention receiving calls from the countryside, and often refer to the readers' opinions in reasoning for or against decisions. At the same time, the newspaper has no wide readership base in Khanty-Mansiysk, and its range 
of readers may be shrinking in the countryside as well, as according to Consultant 2 ten years ago the reporters were able to freely take interview in Mansi, while now they have only a few Mansi interviewees, in most of the cases they need to translate the interviewees' answer to Mansi.

\subsubsection{Topics and language}

The range of topics discussed in the Mansi newspaper has widened and changed a lot during its three-decades-long existence, still there are subjects regularly reoccurring on the pages of Luima Seripos. Not surprisingly, the list of evergreen topics includes Soviet and Russian public holidays such as International Women's Day (8 March), Labour Day (1 May), and Victory Day (9 May), as well as political events such as general and local elections. Portraying the representatives of local, especially Ob-Ugric intelligentsia and the Mansi and Khanty folk artists proves to be an eternal topic as well.

In 1989 Luima Seripos had, naturally, quite a socialist character, celebrating Soviet memorial days like Lenin's birthday, discussing agricultural news such as the end of harvest or the beginning of the summer fishing season. Nevertheless, it is worth mentioning that, at the same time, the earliest issues were also more open and outspoken: the newspaper regularly featured letters from the readers, usually complaints, resenting social problems, even crimes.

The range of topics discussed became more diverse over the years, the modern newspaper differs from the first volume not only in dismissing directly socialist subjects, but also by including various new trends and topics. One of the most important innovations is the representation of urban events and contemporary lifestyle: reports about conferences, film festivals, and even beauty contests, as well as interviews, features articles on agriculture, economics, or the oil industry. Another strengthening line is the introduction of traditional ObUgric cultural events (bear feasts, crows' day, or the day of the reindeer herders), as well as featuring honoured members of the Ob-Ugric society working outside the sphere of science and folk art (religious leaders, and heads of families). Politics have not lost any of its significance over the decades, although the political orientation appears to be somewhat different: in addition to interviews with local politicians (often the same politicians as 30 years ago) the newspaper also publishes greetings and announcement, both politicians greeting the readers and the 
newspaper greeting politicians or other local celebrities. The readers' letters section has undergone a similar change: instead of grownups criticising or complaining, Luima Seripos prefers to publish children's reports on receiving their ID cards or participating in summer camps.

According to Bíró and Sipőcz's 2009 finding, the language used in Luima Seripos is considerably different from the variety documented at the turn of the $19^{\text {th }}$ and $20^{\text {th }}$ centuries. They found considerable change in the use of the passive structure and evaluated this as simplification explained by language shift, as well as inconsistencies in the use of the dual. The lexical investigation resulted in finding significantly more Russian loanwords as well as Mansi neologisms (Bíró and Sipőcz 2009). The formation, distribution and semantics of the Mansi neologisms in Luima Seripos were also investigated by Virtanen (2020), while the terminology of mother tongue and indigenous languages by Bíró and Sipőcz (2017).

\subsection{Mansi broadcast media}

A very limited number of programs is available in the Khanty-Mansi Autonomous Okrug in Mansi, and a very limited amount of information is presented about them. The Yugoriya Television and Radio channel and the local branch of the of the state-owned Rossiya television channel have been broadcasting regular programs in the indigenous languages, in Khanty since 1992, and in Mansi since 1994. The indigenous newsroom Ochag (Oчaz, 'fireplace' in Russian) was founded in 1995, lately employing one Khanty and one Mansi speaking reporter.

The channel airs news in Mansi every second week, for approximately 30 minutes in the framework of Uvas mir putar (Увас мир nymap, Khanty for 'the word of the peoples of the North'). ${ }^{35}$ The program Yomvosh Shunyang Yoh (Ёмвош шунянг ёx, 'happy people of KhantyMansiysk' in Khanty) occasionally broadcasts videoclips in Mansi as well. ${ }^{36}$ In addition to these

\footnotetext{
${ }^{35}$ The online archive of the program is updated irregularly and does not indicate whether the language of the broadcast is Khanty or Mansi. http://www.ugoria.tv/program/7206/

${ }^{36}$ The online archive of the program is updated irregularly and does not indicate whether the language of the broadcast is Khanty, Mansi or Russian. http://www.ugoria.tv/program/7205/
} 
programs the broadcast Ugorskoye nasledyie (Угорское наследие, 'Ugric heritage' in Russian) aims to reach Russian monolingual viewers.

Radio Yugoria broadcasts news in Mansi in its programs Taryg Tursuye (Tapblz mypcye, 'the crane's voice' in Mansi). The regional TV-channel Yugra has been producing episodes of the children's serial Yugorika, ${ }^{37}$ a television project dedicated to the study of the Khanty and Mansi languages, since 2011 (KMNS HMAO 2019: 5).

\subsection{Theatre}

The Theatre of Ob-Ugric peoples employs specialists of Ob-Ugric culture. The consultant of choreography Faina Pavlona Ishtimirova, and the consultants of folklore Tatyana Aleksandrovna Moldanova and Timofey Alekseevich Moldanov were Khanties, while the consultant for folk music was Dmitriy Grigorevich Ageev, the director of the folklore collective Saly lyengkh (Са̄льл лё̈уx, 'reindeer trail' in Mansi) in Saranpaul, and the musical instruments were created by Anatoliy Vasilevich Vadichupov, a Mansi sculptor and artist. The first collective of the theatre counted seven artists, three of whom, Vladimir Savelyevich Merov, Elena Vladimirovna Frizorger and Galina Mihaylovna Yaptina, were Mansis. The plays put on during the first years where either based on the folklore of the Ob-Ugric peoples, or they celebrated Khanty and Mansi writers, poets, and artists such as Gennadiy Stepanivich Rayshev, Andrey Semenovich Tarkhanov, Mikul Ivanovich Shulgin.

In 2010 the Theatre of the Ob-Ugric peoples was given new management, AnnaKseniya Vishnevskaya, an originally Moscow-based actress took the art director's position. The character and style of the theatre have undergone notable changes: instead of the symbolic use of Ob-Ugric folklore the theatre started to focus on the prominent historical events of the $20^{\text {th }}$ century, and in addition to plays of Ob-Ugric character (e.g. Tatyana Aleksandrovna Moldanova's Black song about the Kazym uprising), world-known classics of world literature were included (e.g. Aitmatov's The day lasts longer than a hundred years or Marquez's Diatribe of love against a seated man) to the repertoire, and instead of using the formal language

\footnotetext{
${ }^{37} \mathrm{https}$ ://ugra-tv.ru/programs/detskie_teleprogrammy/yugorika/archive/
} 
of ethnofuturism ${ }^{38}$ the theatre started to prefer the world of magical realism. The founding members left the troupe one after the other, while the newly recruited actors started to attend professional training at the Ekaterinburg State Theatre Institute.

Since the Theatre of Ob-Ugric peoples is the only theatre of Khanty-Mansiysk, in addition to representing the Ob-Ugric peoples it also aims to entertain the majority as well, thus most of the plays are presented in Russian, while there are plays partly or completely in one of the Ob-Ugric languages. The management and the art director speak Russian only. Every actor of the Theatre of Ob-Ugric peoples belongs to one of the indigenous ethnic groups of the Khanty-Mansi Autonomous Okrug, but by far not everyone among them is able to speak Khanty or Mansi. The protagonists of the plays in Khanty or Mansi are often chosen irrespectively of their proficiency, thus before staging Khanty or Mansi plays, consultants visit the theatre to boost the actors' language skills: they rehearse the text and organise language classes on demand. During the rehearsals, language speakers help the language learners to correct their pronunciation, also the speakers of the same language or variety use Ob-Ugric languages between themselves while not on stage. Currently three Mansi-speaking brothers are working for the theatre, at least two them reported to be able to speak Komi as well.

The audience of the plays are mostly Russian-speaking locals of Khanty-Mansiysk. In the case of children's plays, school children visit the theatre in organised trips from primary schools in town, the staged pieces of Ob-Ugric literature are often played for visitors visiting in Khanty-Mansiysk for conferences and forums, while works of world literature are followed by mixed audiences, including local residents with no connection to Ob-Ugric institutions. The non-intellectual native speakers of Khanty and Mansi usually visit the premieres. In the 2000s the plays staged primarily in Khanty and Mansi were provided with Russian translation of the scenario, while in the 2010 s the preferred method became to include the Russian translation in

\footnotetext{
${ }^{38}$ According to legend, the term 'ethnofuturism' was coined in the second half of the 1980s half-jokingly, halfseriously by some Estonian young people. Ethnofuturism was originally a literary trend, cultivated first and foremost by the Võru poetess Ülle Kauksi. The motto of ethnofuturism was to cover the old content in a new form, that is, to revitalise traditions by reinterpreting and adapting them to modern times. The trend has never gained considerable popularity in Hungary or Finland, but it has become popular in Estonia and among the Finno-Ugric peoples of Russia. Ethnofuturism was especially well-known and practiced in Udmurtia, where the leader of the best-known ethnofuturist group has been the shaman Kuchiran Yuri (Yuriy Nikolayevich Lobanov), the designer of the flag and coat of arm of Udmurtia, and the most famous representative of the style has been Olga Yakovlevna Aleksandrova (Владыкин - Розенберг 2004: 146-147).
} 
the play itself, often by means of employing an actor narrating the plot in Russin. The era marked by ethnofuturism was often taken as strange by majority visitors and questioned by $\mathrm{Ob}-$ Ugric intellectuals, while since the establishment of the new art management no such criticism has been raised.

\subsection{Mansi popular music}

The schedule of the Theatre of the Ob-Ugric peoples fundamentally differs from the routine of European theatres: it follows the office hours of a museum. The actors need to spend their working days sitting at the theatre hall, which - if the director or the art director is unavailable - means plenty of useless hours. The actors usually spend these hours preparing folk costumes or playing folk music inspired instrumental music.

Valentin Nettin (stage name: Valya86), a Khanty actor working for the Theatre of ObUgric peoples since 2013, is famous in Khanty-Mansiysk and gradually also all over the Okrug for writing and performing poems and hip-hop music. Many of his songs talk about the distressed and struggle-filled life of Khanty and Mansi youngsters, unable to find their place torn away from traditions, but not yet accustomed to the globalised world either. Anna-Kseniya Vishnevskaya directed a concert-performance titled 86Region ${ }^{39}$ based on Nettin's songs. Since Nettin did not have the opportunity to acquire the Khanty language in childhood, he writes and performs his songs in Russian, but his fellow-actors featured at the concert singing the Khanty lyrics and dancing the sacred Ob-Ugric dances. With his musical performance, Valentin Nettin created the concept of Ob-Ugric popular music.

Yevgeniy Anyamov (stage name: Bizzo), a young Mansi born in Treskolye, later living in Ushma (both are Mansi villages located in the Ivdel region of the Sverdlovsk Oblast) writes and records Mansi freestyle rap. The Mansi of the Ivdel region have been in many linguists' and ethnographers' focus of interest, Russians as well as foreigners, starting with Antal Reguly in the $19^{\text {th }}$ century, followed by Valeriy Chernetsov in the beginning of the $20^{\text {th }}$ century, and by the late Gábor Székely in the $21^{\text {st }}$ century (cf. Секей 2012, B. Székely 2013). Yevgeniy Anyamov is not the first famous musician from Treskolye, as the result of almost two years'

\footnotetext{
${ }^{39}$ The number 86 refers to Nettin's year of birth as well as the license plate digits associated with the KhantyMansi Autonomous Okrug.
} 
fieldwork an LP with traditional Mansi music and contemporary electronic accompaniment was published in 2005 (Гончарова - Мулчанов 2005).

Until the first half of 2020 he recorded four tracks, all telling about his home village Treskolye, his family, his identity as a Mansi rapper, as well as the loss of his connection to traditional lifestyle, as it is pictured in his song Руттанум ('Relatives' in Mansi).

In 2019 he created a clip for one of his tracks, and when he gained popularity after publishing his works on YouTube, he decided to move to Khanty-Mansiysk. In 2020 he is working for the Mansi newspaper Luima Seripos, and with the help of Valentin Nettin, he is planning to record his first album of Mansi rap.

\subsection{Online activity in Mansi}

8.11.1. The history of the Mansi language web

Using the internet became a typical feature of urban life, an integral part of modern everyday life, and online communication has been accepted as one of the domains of language use too. Access to the internet spread in the Khanty-Mansiysk Autonomous Okrug, especially in cities and larger settlements by the late 2000s, in 2014 the penetration rate of mobile phone system was already $145.2 \%$, while the internet penetration rate was $72 \%$ (Югра - электронный регион 2014: 4). The internet users and content creators of Ob-Ugric background appeared in growing numbers since the 2010 s.

The first webpage in Mansi was created by Finnish researchers around 2008, it displayed the history of the early Finnish researchers investigating the Mansi language and culture at the end of the $19^{\text {th }}$ and the beginning of the $20^{\text {th }}$ centuries. The page used many pictures (comics) and few texts, with plenty of grammatical mistakes. This page remained the only Mansi online content for a few years, without any followers among the Mansi or non-Mansi users. The first Mansi sentences written by Mansis appeared on the web at the beginning of the 2010s, especially on the social networking sites: the Mansi have been keeping in touch with their foreign acquaintances on Facebook, while conversing with their friends living in Russia on Vkontakte, many of them having accounts on both sites. 
The official institutions and services providing static content in general are operating with Russian webpages as a rule, if translations are available in other languages, the alternatives are in English, sometimes in Chinese, but not in the local minority languages. Aside from the homepage of the Khanty and Mansi newspapers, no official webpage is available in Khanty or Mansi in the Okrug.

The Mansi Wikipedia is in the incubator, ${ }^{40}$ with a few dozens of automatically generated articles. ${ }^{41}$ Although Ács et al. state that regarding the chances for digital revitalisation "all dialects of Khanty, Mansi, and Nganasan a lost cause“ (Ács et al. 2017: 340), other researchers work on Mansi language technology tools (Horváth et al 2017).

Regarding the DLDP Scale for Digital Language Vitality (Ceberio et al 2018), the situation of Mansi digital vitality is most characteristic for Emergent Level, since Mansi definitely enjoys only limited technical support, having fonts (designed in the Khanty-Mansi Autonomous Okrug) and keyboard layout (designed in Norway), a few digital language resources (e.g. Horváth et al 2017), and the language is used first and foremost on social media pages. Mansi definitely aspire to move on to Developing Level, as basic electronic resources and machine translation are in the making.

\subsubsection{The Mansi vocabulary of IT and the internet}

The principles of Soviet linguistic policy, according to which the Mansi literary language has been designed, changed from time to time. While until the 1950s the more general tendency was to create new Mansi words to describe formerly unknown phenomena, later the usage of Russian loanwords became more dominant. Since the 1990s the tendencies governing the planning of Mansi language use and language acquisition have become multidimensional, important differences and interferences may be observed between the various actors of language use, especially the leading specialists (mainly following the Soviet academic policy) and the journalists (using and promoting the language on a daily basis, with the largest active number of followers).

\footnotetext{
${ }^{40} \mathrm{https}$ ///incubator.wikimedia.org/wiki/Wp/mns

${ }^{41}$ https://incubator.wikimedia.org/wiki/Special:PrefixIndex/Wp/mns/
} 
Thus, it is not surprising that the IT vocabulary, with the sole exception of neyamaümaн йильпи сыр машина, 'new kind of typing machine', a term used for the computer (Ромбандеева 2005: 113), is missing from all the dictionaries, while - although using the neologisms rather inconsistently - the new terms created by the journalists appear in the Mansi newspaper. The most important Mansi IT term is umxünbly ym 'extraordinary thing', as in examples 1-3.

(1) Нйврамыт район ос округ янытыл ищхйпыу ут (интернет) хосыл конкурсыт ос ощухулт ва̄рыглэ̄гыт. (1091, 2015. 01. 16.)

"The children in the rayon and the okrug make contests and jokes along the extraordinary thing (internet)."

(2) Исколавт ань эрнэ матыр пуссын ӧльь - сырсыр ищхӣпыуу утылы (компьютерыт, интернет, интерактивный па̄ртыт), ма̄нти ло̄пс (сайт) тот орньщееве. (1091, 2015. 01. 16.)

"Now all the required things are in our school: all kind of extraordinary things (computers, internet, interactive whiteboards), we even have a page (site) there."

(3) Таима̄гыс [person's name] «Фейсбук» сайт нампа ищхйпың утыт акв ло̄nc ва̄pblc. $(1070,2014.02 .21$.

"Because of this, [person's name] created a page on the extraordinary thing called Facebook."

The term 'extraordinary things' has been being used for all kinds of technical novelties, until it settled to mean 'internet'. The internet in the Mansi newspaper is very much personalised, or at least regarded as a solid, concrete entity which 'is made' (as in Examples 4 and 5), and which can 'work'.

(4) Школат интернет ва̄рвес. $(1087,2014.11 .07$.

"The internet was made at the school."

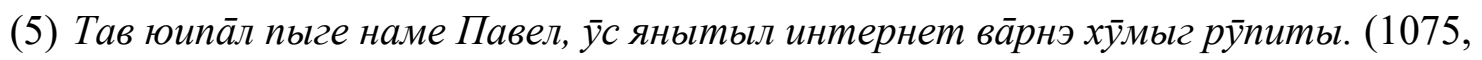
2014. 05. 09.)

"After him comes her son called Pavel, he works as an internet-making person in town." 
(6) Интернет рӯпиты, ка̄сыу колнакувт электронный па̄рт о̄льы. (1056, 2013. 07. 26.)

"The internet is working, electronic whiteboards are in every room."

The understanding of the internet in the Mansi newspaper appears to be very practical. The first mentions introduce the internet as the source of knowledge, which - besides its implicit value - is precious because of the limited information available locally, especially in villages, as described in Examples 7-9.

(7) Сакати ты нэ̄пакыт нйврамыт ловиньтэ̄гыт. Ань май интернет нампа

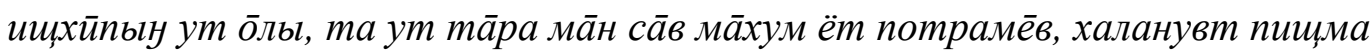
хансэ̄в. (1063, 2013. 11. 08.)

"Children don't read these books very much. Nowadays there is this extraordinary thing called the internet, across this thing we speak with many people, we exchange letters."

(8) Ань йис нйврамыт ловиньтан нупыл тэ̄ланыл сака пыл а̄ти, юн са̄всылр компьютерт ман интернет ӧньщёгыт, номтаныл тувле нупьл мины. (1063, 2013. 11. 08.)

"The children don't have much to do with reading the old things, at home they have all kinds of computers or the internet, they prefer to go there."

(9) Ма̄н библиотекат туп 18 сортыра арыгкем нэ̄пак о̄ньщеев. Тыи ма̄гсыл ты компьютер сака эри, интернет хосыт са̄всыр нэпак хӧнтункве ос ловиньтаукве ровви. $(1077,2014.06 .06$.

"In our library we have just about 18,000 books. Because of this the computer is really necessary, all kinds of books can be found and read along the internet."

Right after recognising the internet as the source of information comes the idea of adding personal knowledge to this data bank, in order to promote hobbies or to gain popularity by advertising talent or performances (examples 10-11). 
"I say: 'You are dancing, we put it on the internet, maybe someone comes across it and gets interested'."

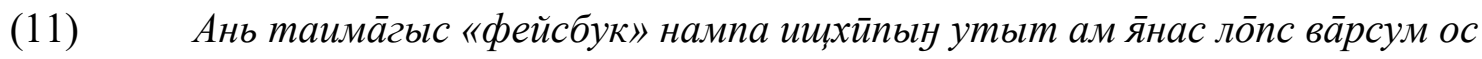
тот товва по̄слум хуриянум суссылтыянум. (1075, 2014. 05. 09.)

"Now because of this I made a separate page on the extraordinary thing called 'Facebook' and I show my photos there."

Besides personal use, the communal benefits of the internet connection are also acknowledged, taking the article in example (12) as evidence for using online communication as a tool for political activity.

Ма̄н округувт ма̄вит урргалан тэ̄ла ань акваг та̄рапаттым о̄ньщаве. Tы

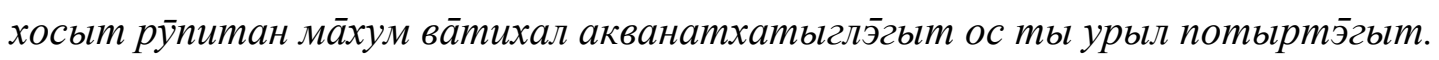
Акв тамле сапра̄ни губернатор ва̄уын хум Геннадий Бухтин ва̄рыглас. Ма̄вит

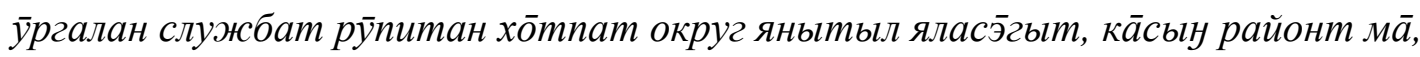

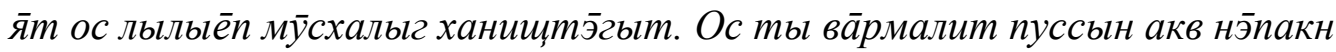
хансыяныл. Ма̄вит урргалан ма̄хум ты нэ̄паканыл щзирыл, Белоярский ӯст лыльееп

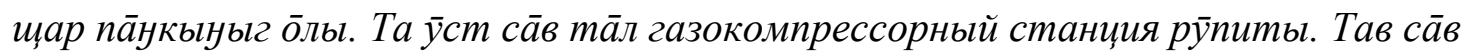
лю̄ль ут кон ты таррты. Щар сыстамыг Кондинский ос Советский районыг

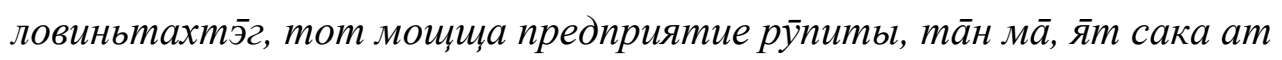

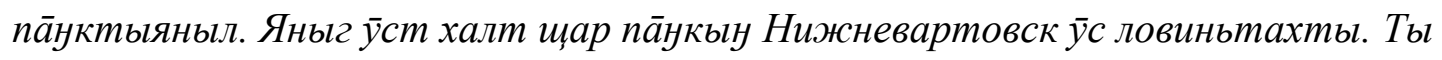
юипа̄лт Сургут, Нефтеюганск ос Ханты-Мансийск уусыт хансым о̆лэггыт.

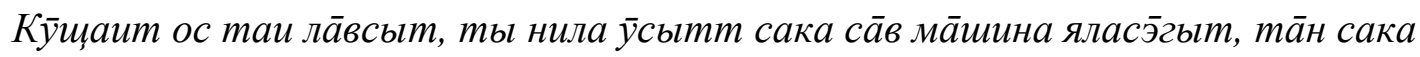

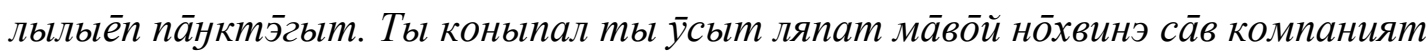

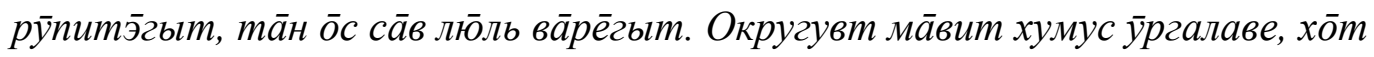
ма̄вит сака па̄уктаве ос хумус сыстамтаве, ты урыл кущщаит ка̄сыу та̄л яныг докладнэ̄пак щеёпитэ̄гыт. Ма̄хум та̄н хансум нэ̄паканыл ловиньтанкве вос веррмёгыт, таве интернетын варрияныл. $(1079,2014.07 .11$.

"In our okrug the protection of the environment is getting more and more important. The people working on this issue often meet each other and talk. One of such meetings 
was organised by deputy governor Gennadiy Bukhtin. The environmentalists go all around the okrug, they investigate all the lands and rivers and the air. And they write all these things into a book. According to this book of the environmentalists, the air in the town of Beloyarkiy is very dirty. In this town a gas compressing station has been working for many years. It exhales many bad things. The clearest rayons are the Kondinskiy and Sovetskiy rayons, very few companies work there, the lands and rivers are not very dirty. Among the cities, Nizhnevartovsk is the dirtiest. After that Surgut, Nefteyugansk and Khanty-Mansiysk are listed. The investigators said that in these four cities too many cars are running, and that makes the air dirty. Beside this, oil companies are working close to these cities, they do many bad things as well. How to protect nature, how to soil and how to clean nature, the investigators read papers about this. In order to let the people be able to read this book, they put it on the internet."

It is important to highlight the problem introduced in example (12) being online in two ways: the reference book on environmental pollution was published on the web, similarly to the article discussing it, while it is hardly conceivable to make the original work widely accessible in printed form or to speak about the debates concerning pollution in the offline media.

\subsubsection{Online Mansi language use}

There is widespread access to the internet in the Khanty-Mansiysk Autonomous Okrug, especially in cities and larger settlements till the late 2000s, while internet users with Ob-Ugric background have appeared in growing numbers since the 2010s. As using the internet became an integral part of everyday life, online communication became one of the domains of language use too, and regarding the virtual sphere as a part of the complex understanding of linguistic landscape cannot be avoided either.

The tendencies determining language use in the online sphere are rather similar to those determining the offline domains. Accordingly, official institutions and services providing static content in general are operating with Russian webpages. If translations are available in foreign languages, these are in English, sometimes in Chinese, but not in the local minority languages. Aside from the homepage of the Khanty and Mansi newspapers no official webpage is available in Khanty or Mansi in the Okrug. 
The main difference between the language use of the online and offline domains can be found observing the activity of private internet users. Since web 1.0 media sites offer neither content in Ob-Ugric languages, nor the possibility to fill this absence, the Ob-Ugric users and the content created by them either in Russian or in Ob-Ugric languages are to be found typically on various sites of social media (to a lesser extent on Facebook, more generally on its Russian equivalent VK.com).

The internet has been playing a dual role in the life of Mansi users. It serves as a tool for sharing, accessing, and storing Mansi content created for other domains, primarily used by the press and media, and to a lesser extent by individual users. The web (especially the social networking sites) is used as a tool to form and express the Mansi users' (ethnic) identity segments, and to promote their offline contributions, such as exhibitions, art and scientific work, concerts, and performances. Besides being a tool, the web serves also as a domain of Mansi language use. Mansi internet users use the web, especially their private accounts and a small number of thematic groups to communicate in Mansi.

It may be more problematic to separate the elements of the linguistic landscape from private language use in the online sphere than in offline domains, still specific online and offline tendencies can be observed. The users of Ob-Ugric languages are surrounded by the dominance of Russian online just as much as in the physical world, yet the presence of Ob-Ugric signs and other elements as well as their creators is more intensive and visible in the virtual linguistic landscape. While in the offline world even native speakers of Ob-Ugric languages are rarely witnessed to have impact on the linguistic landscape surrounding them, in the virtual sphere users with minimal command of Khanty or Mansi publish short texts in Ob-Ugric languages both in private and public domains, and initiate conversation in Mansi with native speakers. Still, while comparing the more or less active domains of language use, it is necessary to emphasise the relativity of such activeness: the online users of Mansi are surrounded by the dominance of Russian online just as much as in the physical world, and the use of Mansi remains marginal and incidental besides the use of Russian.

\subsection{Religious activities}

\subsubsection{The Mansi and Christianity}


Early reports about the beginning of Russian colonisation in Siberia in the $16^{\text {th }}$ century do not commemorate the destruction of Ob-Ugric ritual sites, do not mention mass baptisms taking place or any converts by name. At this stage of settlement, there were not enough armed forces in Western Siberia to protect Russian settlements, and the government therefore banned forced baptism in order to preserve peace. On the other hand, the Orthodox Church did not have a sufficient financial background, nor did it have enough priests to carry out proselytising until the establishment of the Diocese of Siberia. Moreover, the priests living in the area were in most cases exiled to Siberia for some (not exclusively political) crime, so their example and way of life could not be very attractive to the indigenous population. In this first wave, women marrying the occupying Cossacks or Russian farmers, men unable to pay the bridal price or the annual fur tax were baptised.

The attitude of the state administration towards the indigenous peoples changed in the $18^{\text {th }}$ century, when Tsar Peter the Great ordered the Orthodox Church to convert the Siberian natives. As a result of the work of Metropolitan Filofey and his helper, Grigory Novitsky, more than 40,000 indigenous persons were baptised, hundreds of idols were burned, and churches were built on the ruins of the sacred sites. The initial enthusiasm of the missionaries faded soon, because their work had no lasting effect, and the indigenous people became Christians only nominally. On the one hand, the Orthodox Church was not completely successful spreading Christianity partly because of the presence of not only the indigenous peoples, but Old Believers as well, while, on the other hand, following their traditional beliefs and practices was not only an ideology for the Ob-Ugric peoples but also the imprint of their lifestyle, thus the guarantee of their survival. During Soviet times the intolerance towards Ob-Ugric religious practices from the Orthodox Church was replaced by political doctrines (cf. Glavatsaya 1996).

\subsubsection{The classification of sacred Mansi sites}

The study of sacred sites has been a popular field in the research history of the ethnography of Finno-Ugric peoples. Julius Krohn first gave the definition of sacred sites as places "where they have presented their wishes and requests to their gods, or given thanks and glorified them for the gifts they have already received" (Krohn 1908: 29; my translation). The two key elements of his definition are that the site as residency of deities and holding rituals here. He also attempted to classify sacred sites according to rather formalistic criteria, that is, 
whether they were natural or artificial sites, and whether there were ritual buildings erected there. According to his description,

"they [the Mansi] did not dare to mow the grass, cut down trees, hunt or fish here, even to drink water from the river, lest the gods be angry. Traveling along them, it was not allowed to moor, not even touch the shore with a paddle. [...] We also find sacred groves at the Ugric peoples, in which nothing should be touched and in which animal skins and other sacrificial gifts are hanging. But compared to the Western [Finno-Ugric] peoples, we notice the important difference that the sacred sites are not separated by a fence from the rest of the forest. [...] The Voguls have certain sacred places where they have common idols. [...] In the past, all these collected goods were kept in separate warehouses; these repositories were of great importance in the management of the people; although donations to some part, like furs, deteriorated over time, money and precious metals remained. They served as a kind of people's bank from which they could borrow in bad years, repay in better times" (Krohn, 1908: 77-79, my translation).

Karjalainen divides the Ob-Ugric deities into two main groups according to whether they have sacred sites or not (Карьялаинен 1995: 7). According to his classification, sacred sites can be (a) long-abandoned settlements, former towns where epic heroes lived and fought; (b) old cemeteries that are no longer in use, but their location is still known; (c) places of special, unusual appearance; and (d) places seen in dreams or visions, declared to be sacred by a deity.

Most of the Mansi sacred sites belong to the category of local sacred sites. Jalpyng maa

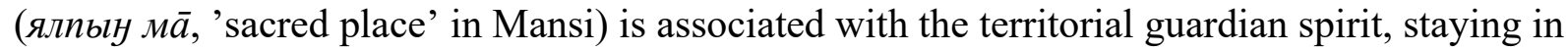
the territory is governed by strict rules: all economic activities are prohibited in the sacred place, hunting also must be stopped if the prey reaches the sacred place. Women are not allowed to enter the sacred place, often not even to pass by it on the river, in such cases they have to come round it on a special path called ne-lyongkh-sunt (нээ лёух суйm, 'entrance to the women's path') (Mansi mythology 2008: 65).

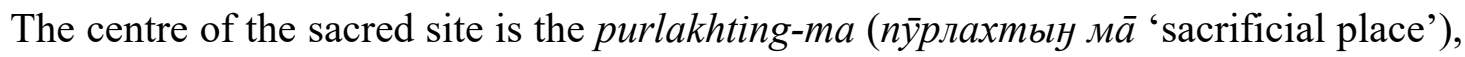
there stands the sacred storehouse on poles and the fire place. The number of visitors to these places was originally limited to the male residents, but today this rule seems to be eased as far as foreign men and, in some instances, women are concerned. Women have a separate place of

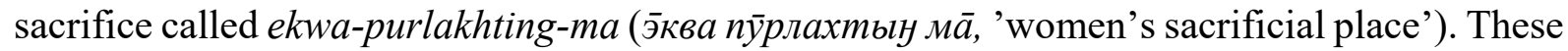


are located close to the villages, and although they are open to men, men still do not go there often. There are no records of such sacred sites form the $18-19^{\text {th }}$ centuries, while in the $20^{\text {th }}$ century there were two main types of them, one with a tree in the centre of worship, and one with anthropomorphic depictions of deities. Sacred sites for women are related to the kinship system, due to exogamous, patrilocal marriages, women generally diverged from the guardian spirit of their own village. For this reason, women's sacred sites usually have more universal, more neutral gods as their guardian spirits (Mansi mythology 2008: 162; Гемуев - Сагалаев 1986: 124-125).

Gemuev and Sagalaev list three categories of sacred sites: first, places of worship of water deities (место почитания обитателей водньх стихий). These sacred sites always belong to the surrounding settlement, but not every settlement has such a sacred place (Гемуев - Сагалаев 1986: 125). Speaking of Vasyugan Khanty sacred sites, Nagy considers the worship of water spirits universal, but he finds it unproven that they would belong to settlements and does not separate the worship of water spirits from the worship of forest spirits (Nagy 2007: 113-114). Second are local, territorial sacred places (культовые места территориальных гpynn). According to Gemuev and Sagalaev, in the case of territorial sacred sites the circle of worshipers was not organised on the basis of fraternal relations but on territorial ground. The third type of sacrificial places are memorials of mythological battles, feats, and events (паметные места). According to Gemuev and Sagalaev, the Mansi do not call such sites purlakhting-ma and do not make sacrifices there (Гемуев - Сагалаев 1986: 125-131).

Besides the mentioned categories, Popova also registers a certain unttilakhting-ma (унттылахтылу ма̄, 'place for funeral feast'), a sacrificial place which is not regarded sacred, citing the cemetery as an example (Попова 2003: 41). Nagy introduced the concept of sacred places inside a residential building. The three prominent scenes of the sacred places within the house are the red corner, the stove, and the attic. Like the natural sacred sites, sacred places located inside the house can be associated with supernatural beings and require special behaviour (Nagy 2007: 119).

\subsubsection{Mansi sacred sites in Khanty-Mansiysk and its environs}

Khanty-Mansiysk is situated in a more or less plain territory, but according to the local saying, it is located on seven hills, thus it is quite natural to find the urban Mansi sacred place 
on the top of one of these hills. Since most of the hills have houses, hotels or monuments built on their tops, while the Torum Maa Open Air Museum, easily accessible from any spot in town, has not only traditional Ob-Ugric buildings, but a reconstructed sacred place as well, it was a reasonable decision to use the museum for ritual purposes. Both the ritual buildings at the museum and the sacred elements added to the site by the visitors are obviously non-traditional and purposefully designed. The location of offerings (ribbons tied to the trees) for example is often questionable the most striking example is the birch tree next to the building closest to the museum entrance, on the branches of which the ribbons appeared not earlier than 2008 . Although the birch tree is regarded sacred by both the Ob-Ugric peoples and Russians as well, the particular specimen is growing next to the house many kol (мань кол, 'small house'), a building designated for women to stay at during menstruation and childbirth.

Khanty-Mansiysk historically had no Mansi population of considerable size, the Mansi, practicing their traditional faith in the city, have arrived from other parts of the Khanty-Mansi Autonomous Okrug, thus no consultants could name Mansi sacred sites in Khanty-Mansiysk or its vicinity. The only exception, Consultant 2, named a hill in the quarter of Samarovo, on the banks of the Irtish river, near the sports centre Ledovy Dvorets. According to her report, the hill was regarded sacred to such an extent, that women were not even allowed to look in its direction, still, the consultant was unable to name the deity of guardian spirit taking custody of the place. But he could not tell exactly which god or guarding spirit was worshipped there.

The third sacred site of Mansi character, the Mansi poet Yuvan Shestalov's fortified shrine is to be found on the outskirts of town. Shestalov started to build his sanctuary $36 \mathrm{kms}$ from Khanty-Mansiysk in the direction of Nyagany and named it the Fortress of the WorldObserving-Man ${ }^{42}$. In 2008 the fortress complex consisted of a two-storey house, a kitchen, a plastic-covered Mansi-type tent, a steam bath, and outhouses, surrounded by a log fence. According to Shestalov's own interpretation, the number of the buildings in the fortress should equal the number of Finno-Ugric peoples to symbolise Finno-Ugric unity. The complex burnt down in 2010, but eventually Shestalov started to rebuild it, and the fortress became his resting place in 2011.

According to Shestalov the fortress was situated at the closest possible place to the original location of Belogorye, the centre of veneration of the Mansi deity Mir-Susne-Khum. The ritual centre of Shestalov's fortress has been the holy larch in the Western corner of the

\footnotetext{
${ }^{42}$ Городище «Мировой Смотритель»
} 
court, decorated with scarves and fabric ribbons of different colours. The second ritual centre focused around another larch tree and Shestalov's pulpit was located about 50 meters from the entrance to the fortress, next to the nearby creek. Although in the 2000s the complex had heating and running water, Shestalov used it as his dacha, and he frequently invited over guests to celebrate rituals for them. During my visit in 2008 he greeted his guests at the larch in the court, made food sacrifice, prayed in Mansi to Numi-Torum and Mir-Susne-Khum for good health and a long life, as well as asking them to protect the Mansi people and to give them wisdom. Then he led his guests to the other larch tree outside the wall. No special sacrifice was made for this tree, although Consultant 107 mentioned that the person praying in front of the tree after hugging and kissing it, would have their wishes granted. Shestalov climbed to his pulpit and preached from there for about a quarter of an hour, using quotations from Mansi folklore texts published by Munkácsi.

\subsubsection{Rituals at the Torum Maa Museum}

Since in Khanty-Mansiysk business tourism seems to outstrip leisure tourism, to a great extent the inhabitants of Khanty-Manysiysk constitute the group of visitors at the open-air museum. To attract domestic tourists, the museum regularly organises events celebrating various Ob-Ugric holidays, for example the day of Treating the Moon ${ }^{43}$ or Crows' Day ${ }^{44}$ in the spring, and occasionally the Bear Festival in the winter. These events are advertised in the local press, media, and online social media, and usually attended by journalists. The organisers try to find the golden mean of balance between rituals carried out in traditional ways and organising a music-hall performance featuring the local Ob-Ugric ensembles, where the program is usually carried out in Russian or Russian translation is provided.

In addition to public events, the open-air museum gives home to occasional private rituals, organised by Khanties, Mansis, or representatives of both ethnic groups together. When the rituals are held by the Mansi living in Khanty-Mansiysk, the organisers are young men and middle-aged women, following the guidelines of the most venerated community members, e.g. Consultant 1 . These events are not advertised in advance, the participants are invited by word

\footnotetext{
${ }^{43}$ Угошение Луны

${ }^{44}$ Вороний день
} 
of mouth. At the scene people are discouraged from making recordings or taking photos, with the restriction most likely serving the anonymity of the participants, because at rituals organised by limited numbers of participants or at other (more traditional, thus possibly more sacral) sites I was even encouraged to document events. During the rituals only the Mansi language is used between the participants. The precentors pray in louder voices in Mansi, and private prayers uttered in hushed voices are delivered in Mansi as well, even if the participant knows only the basic blessing formulas.

\subsubsection{Attitudes towards sacred sites in Khanty-Mansiysk}

The majority of consultants using the Torum Maa museum for ritual purposes are middle-aged Mansis habitually residing in Khanty-Mansiysk, still maintaining a relatively living contact with their home region, that is, they are regularly visiting their relatives and the sacred sites of their home village. They bring sacrifice there typically once a year, or if they are unable to travel home, they send a scarf donation.

Generally speaking, the Mansi living in Khanty-Mansiysk are aware of the fact that the historical sacred sites in town are of Khanty origin. In 2008 Consultant 21 mentioned the celebration of the Crows' Day at the museum, although, according to her, all the sacred sites of Khanty-Mansiysk are Khanty. Consultant 3 stated, in 2008, that although she considered Belogorye to be the ritual centre for the Mansi of Khanty-Mansiysk and regarded the sacred sites of Khanty-Mansiysk to be Khanty, she had been visiting the events organised at the Torum Maa museum, taking her children along also. As Consultant 42 commented in 2009, she preferred to pray at home instead of visiting the museum, because she had been told that only the Khanty were allowed to pray there, while the Mansi were supposed to do it at home, which she considered unfair. Her comment made in 2015 reflects the changed situation, since only six years later she already reported visiting the ritual events at the museum, at least 15-20 times per year, with pleasure, and considered the Ob-Ugric rituals to serve as the only domain of language use not related to family or profession. She presumed that the Mansi of Khanty-Mansiysk are in a better position for maintaining the Mansi language and are able to speak Mansi better than the Mansi living in villages, since in Khanty-Mansiysk they may regularly gather at the museum and speak Mansi with each other. 
The demand for creating a sacred site in Khanty-Mansiysk for the Mansi inhabitants of the city first appeared at the beginning of the 21 st century, the initiators started to use the territory of the already existing Torum Maa museum for ritual purposes, and after a short transitional period the museum indeed started to function as a place of Mansi ritual practices as well as a significantly important domain of urban language use.

\subsection{Summary}

Although Consultant 3 quotes her friend referring to Mansi as щуаиу лартыy ("tea language" in English), indicating that Mansi has no function in communication any more, and it is only used for chatting during tea breaks at work, the picture of urban Mansi language use is more diverse than that. Several domains of Mansi language use may be found in KhantyMansiysk, besides the obvious use of the language in Mansi families, Mansi is also used in oral and/or written form in education, press, television and radio programs, in recreational or artistic activities such as theatre plays or popular music, in religious life and on the internet.

There are no kindergartens in Khanty-Mansiysk where Mansi is taught or spoken. There is no primary school in Khanty-Mansiysk where Mansi is taught or spoken, although consultants mentioned several occasions when parents demanded to start classes with Mansi language teaching in various primary schools, and two attempts have been mentioned when an experimental class was announced for upper grade students, but these endeavours have not been followed by new ones, allegedly because of the lack of proper Mansi textbooks and suitably trained teachers. Mansi was taught at Yugra State University until 2010, since then all the teachers who could teach or speak it have left the university. The training programs for teachers in Mansi for kindergarten and lower grades are still offered at the pedagogical college, but very few students wish to attend them, and even those very few students are reported to have low to no proficiency in Mansi. The only educational institution regularly featuring Mansi classes is the Lylyng Soyum Centre, discussed in details in Chapter 10.

Since the Mansi children journal Vitsam is a one-person project and is distributed in Khanty-Mansiysk only, Mansi press virtually equals the Mansi newspaper Luima Seripos. The newspaper has a 30-years-long history, the editorial board has employed speakers with native competence and broad network of contacts with various layers of Mansi society, the articles are covering the leading topics of their times. The Mansi radio and television programs are more 
difficult to evaluate, as they are difficult to catch on air, they are unsystematically stored or not stored at all, created by single Mansi authors instead of a collective of co-workers. The domain of Ob-Ugric theatre art is characterised by the stabile presence of a creative stuff, but only sporadically available works in Mansi, thus providing a constant domain of Mansi language use for the artists, but an irregular domain for the audience. The research of the spread and the impact of Mansi popular music on language use would be very promising, but the first Mansi performer started his carrier only a year ago, thus the history of Mansi popular music is too brief for analysis. In the online sphere the Mansi language is present on Web2.0 domains only, while no static content or official information is available in Mansi, independent users use Mansi while posting or chatting with their Mansi-speaking friends.

The oldest Mansi in Khanty-Mansiysk usually attend only representative events at the various domains: they attend theatre premiers, give interviews to the Mansi newspaper and broadcast media, visit classes in the alternative educational institutions. The representatives of the youngest generation of speakers usually attend only the newly created urban domains of Mansi language use such as theatre plays and concerts, as well as Mansi programs. The middleaged speakers operate the vast majority of domains: the education, the press and media, and they are also active on the internet and in the domains created by the youngest generation, also providing their expertise if requested. The only domain which is used exclusively in Mansi and by all generations of speakers is the sphere of religious activities. 
9. The role of the Mansi language in constructing ethnic identity

\subsection{Methods}

While the number of Mansi speakers is decreasing, the number of those identifying themselves with Mansi ethnicity is at its highest ever. These figures raise questions about the relationship between Mansi language skills and Mansi identity as well as about the place of the Mansi language among other markers of ethnic identity. The research into the hierarchy of the markers expressing indigenous ethnic identity among the Ob-Ugric inhabitants of KhantyMansiysk was carried out in the framework of the project "Minority languages in the process of urbanisation: A comparative study of urban multilingualism in Arctic indigenous communities" (OTKA grant K 112476).

In the investigation, I asked informants living in Khanty-Mansiysk who are linked to Ob-Ugric institutions in the city through employment or student status to prioritise the identity markers involved in the formation and expression of indigenous minority identities. The list of identity markers was compiled from the following elements, activities, domains closely related to cultures of the observed Arctic indigenous minority peoples living in three areas examined (Enontekiö in Finland, and Dudinka and Khanty-Mansiysk in Russia), as follows:

- living in the traditional territories

- living in a traditional type of building

- fishing, hunting as livelihood

- reindeer breeding

- practicing traditional ritual activities and customs

- knowing traditions and folklore

- owning and wearing folk costumes

- preparing traditional food

- practicing traditional crafts

- playing traditional music and doing traditional dance 
- speaking the indigenous minority language

- having minority ancestors and/or relatives

- participating in the programs of indigenous minority organisations

- appearing in the minority electoral register

After explaining the purpose of the research, I mixed the paper slips containing the Russian description of the mentioned identity markers, then asked the respondents to sort the paper slips in a descending order according to the importance of the identity markers listed on them. I asked the respondents to place markers in parallel if they considered the selected identity markers to be of equal importance, to skip any marker considered irrelevant, and to complete the list by adding any missing markers they felt relevant. After compiling the order of the identity marking elements, I asked the respondents to interpret and justify their decisions.

The ad hoc community of university students participating in the study were brought together in the framework of meetings organised by the Centre of the Peoples of the North at Yugra State University. These student - not independently of the history of university education in Khanty, Mansi languages and cultures - had no contact with the indigenous minority languages of the Okrug or with the speech communities of these languages, thus I did not conduct sociolinguistic interviews with them. I had already examined the language acquisition history and language use of the other informants participating in the research during my previous fieldwork (see e.g. Horváth 2016 and 2019).

9.2. The importance of traditional markers of indigenous ethnic identity

The declaration of ethnicity was a much debated, somewhat controversial, sometimes emotionally overheated subject during the Soviet times and it still is in post-Soviet Russia. According to the Soviet and Russian administrative practices one person may belong to one ethnicity, and according to the census questionnaire a person may have only one mother tongue. In the Soviet Union, ethnicity was registered from 1926 onwards, and it was compulsory to declare it in official documents, including passports as well. Between 1926 and 1975, the 
ethnicity of children born into monoethnic families was registered according to the parents' ethnicity, while children born to interethnic couples received their father's ethnicity. According to the Ministerial Council's Regulation on the Determination of Nationality issued in 1975, every child had an opportunity to declare their statement of ethnicity according to one of their parent's ethnicity when receiving their first passport at the age of sixteen, and this declaration could not be altered later on. Since the change of regime, no citizen of the Russian Federation may be obliged to make a declaration about their ethnicity.

Belonging to what is called small-numbered indigenous peoples of the North, Siberia, and the Far East of the Russian Federation (in Russian: коренные малочисленные народы Севера, Сибири и Дальнего Востока Российской Федеращии) is of particular importance. In the $1920 \mathrm{~s}$, at the time of the creation of this category, the notion referred to approximately twenty ethnicities, while Order №132-p on the sustainable development of indigenous peoples of the North, Siberia and the Far East of the Russian Federation ${ }^{45}$ issued on $4^{\text {th }}$ February, 2009, registers forty ethnic groups. The small-numbered indigenous people are defined as ethnic groups consisting of not more than 50,000 people, living in the traditional territories of their ancestors, preserving their traditional way of life and occupation, and considering themselves an independent ethnic community.

The Khanty-Mansi Autonomous Okrug officially grants special rights and support to the representatives of the three local indigenous peoples, the Khanty, the Mansi and the Forest Nenets, in many areas of life, including health, housing or education, as well as language use, folklore, reindeer husbandry, and traditional forms of religious practices. Thus, granting support for the indigenous peoples eventually makes it necessary to keep records of the representatives belonging to the ethnic groups in question, in some cases not only in the internal administration of the institution in question, but also on the outside cover of the document issued by the institution. ${ }^{46}$

Legislation does not cover the domains of traditional lifestyle, nevertheless, it emphasises the importance of "maintaining and revitalising traditional lifestyle, traditional economic activities, rational nature management, and developing the culture and languages of

\footnotetext{
45 Об утверждении Концепции устойчивого развития коренных малочисленных народов Севера, Сибири и Дальнего Востока России. http:/government.ru/docs/30063/

${ }^{46}$ Consultant 21, for example, reported that the cover of her prenatal care booklet was marked with a red stripe indicating that it belonged to a member of the indigenous minority peoples.
} 
small nations" (Act $\mathrm{N} \mathrm{73-03).} \mathrm{Equally} \mathrm{important} \mathrm{and} \mathrm{almost} \mathrm{all} \mathrm{encompassing} \mathrm{is} \mathrm{the}$ representation of the different characteristics of the traditional lifestyle, both in the local and regional events focusing on the indigenous peoples and organised by the indigenous communities and organisations.

\subsection{The assumed hierarchy of indigenous identity markers}

Prior to conducting the research, I divided the markers of ethnic identity to be included in the study into three groups based on their relation to the urban environment. Living in the traditional area, in traditional building type, together with fishing-hunting and reindeerbreeding lifestyle have been categorised as vanishing identity-markers, just like everyday use of folk costumes; since the presence of the former is logically ruled out by the urban circumstances, while the use of folk costume - although theoretically possible to be worn in Khanty-Mansiysk - has been pushed back into homes in a couple of exceptional cases, and in general is completely missing from the urban palette.

The importance of having minority ancestors and relatives, preparing traditional meals, and practicing traditional ways of handicraft, music and dance are assumed to be translocating elements of identity, as these activities can easily be performed in urban settings. Although ObUgric rituals are closely connected to territoriality, previous studies (e.g. Horváth 2010b) have already shown that Khanties and Mansis have an active religious life in Khanty-Mansiysk itself, both at home and during community events, thus, active participation in religious activities initially was classified as one of the potentially dominant urban identity markers. Similarly, participation in programs of indigenous minority organisations as well as being listed in the planned electoral roll are of predominantly urban character, but these factors were eventually excluded from the study do to their sensitive political nature.

I was anticipating the emergence of new identity markers arising in the urban framework, even though due to their indistinct nature I decided not to narrow them to a predetermined listing. Such potential urban identity markers could be the visual representation of Ob-Ugric languages and cultures in typically urban settings such as the linguistic landscape, entertainment, or the internet, however, contrary to my expectations, no consultant mentioned these or similar elements during the study. Non-traditional markers of urban identity did not appear among the respondents' responses, despite the fact that I had repeatedly and emphatically 
highlighted that the list given was expandable. The absence of the urban domains and markers is even more remarkable as some of the respondents are active in the mentioned domains.

One of the most important questions in the study is whether respondents attribute more importance to the translocating identity markers than to the disappearing ones. Another central question is the position of competence in the indigenous minority language among the indigenous identity markers, and whether there is any correlation between the perception of the importance of proficiency and the individual competence of the respondent.

\subsection{Participants}

While choosing respondents for this research question, the same methods were used as during previous field trips. I visited the Ob-Ugric institutions of Khanty-Mansiysk that had a Mansi profile, that is, the Ob-Ugric research institute, the Lylyng Soyum Centre, the Centre of the Peoples of the North at Yugra State University, the journalists of the Mansi newspaper Luima Seripos, and asked for the help of the Mansi employees, many of whom had helped me several times since 2006. In addition, I contacted other Mansi individuals without institutional background, who had also been involved in previous research, and introduced them to my research topic and methods as well.

It occasionally happened in the course of previous field trips as well that some of the consultants contacted did not wish to take part in the research due to the sensitivity of the topic, lack of personal involvement, lack of motivation or other reasons, yet the participants of the 2018-2019 research as well as the number and explanations of those excusing themselves from participating were significantly different from the usual routine.

Approximately five of the potential respondents refused to participate in the study but did not give reasons for their decision. Approximately 15-20 persons did not categorically decline to participate but constantly delayed the interview date until it was completely dismissed. About five people refused to participate in the identity game but commented on the research question examined during the game, and at the same time they refused me permission to record their comments. However, two of them agreed to their comments to be cited. Thus I am able to work with data given by 16 respondents. 
The reasons for rejection can only be guessed, and there are several possible explanations. One possible explanation is the sensitivity of the topic. The Mansi community, especially the urban circle of the more or less thematising intellectuals is divided, due to its size and various conflicts of interest, and this division in some cases escalated to personal dissension due to the recent economic downturn, the shrinking funding, and the tensions induced by the political attention focused on indigenous peoples. It is understandable that in the course of rivalry over professionality or legitimacy, in the midst of debates criticising the impartiality and competence of rivals, participants and observers of these disputes prefer to avoid formulating their views on the ways of expressing ethnic identity, and, in particular, to discuss the role of proficiency in indigenous minority languages.

Another possible reason for rejection is the political debate surrounding the indigenous peoples of the North and the indigenous peoples in general. The International Year of Indigenous Languages, announced in 2019, brought to the spotlight and resulted in heated arguments over the undeniable problems of Khanty and Mansi language teaching and language use, problems that have not been solved for decades, as well as over recent decisions disadvantageous for the minorities. The situation was further exacerbated a few years ago by the idea of creating a register for the indigenous people of the Okrug (Систему учета...), which would favour the Khanties and Mansis following the traditional lifestyle, thus reducing the amount paid to support indigenous people in general. The creation of the list was not common talk in Khanty-Mansiysk but appeared regularly in the online press. On $22^{\text {nd }}$ January, 2020, the Duma adopted a law establishing the register of indigenous peoples (Закон о реeстре...).

Another possible reason for the rejection is the typical distance keeping to foreigners, especially foreign researchers, which has already been experienced in the Okrug for several years. The authorities' interest in foreigners and in locals who maintained contact with foreigners has been mentioned to me for the first time in 2015, the same year a consultant commented that it would not be advisable for me to meet the visiting instructor from the United States without the presence of a third, Russian person, even though these meetings were always arranged in public and our conversations were held in Russian. I ascribe to this suspicion that some consultants, who had not only helped my research but with whom I also have been on friendly terms, not only refused to help with my research but also postponed or declined the opportunity of a personal meeting during fieldwork in 2018-2019. On 14th August, 2019, a scanned copy of a ministerial decree dated $11^{\text {th }}$ February, 2019 started to spread in the news, 
according to which Russian scientists can meet a foreign person only in the presence of a third, Russian person, and in case of having a meeting after working hours they need the permission of their superior, while in the case of private meetings, they are supposed to write short written records of the meeting and present it to their employer (Иностранеи? ...).

In the light of the above, it is understandable that the sixteen respondents had participated in the study at their workplace, in a group, or at least in front of their colleagues, or had a high degree of professional and personal independence. Respondents 1 and 2 are Mansi specialists interested in maintaining the Mansi language and culture, with extensive expertise unquestioned by the community as well as by outsiders. Respondents 3-9 are students of indigenous minority background with a connection to the Centre of the Peoples of the North at Yugra State University, most of whom met me at the time of the interview for the first and - so far - last time. Respondents 10-13 are native speakers originally from the countryside, now living in Khanty-Mansiysk, working for the Mansi media. Respondents 14 and 15 are artists deeply committed to the culture of the Ob-Ugric peoples, with Ob-Ugric (more precisely, Khanty) family backgrounds. Although the primary purpose of the study was to examine the language attitudes of the Mansi living in Khanty-Mansiysk, Khanty respondents volunteered to participate in two groups, the students and the artists.

\begin{tabular}{|l|l|l|l|l|l|l|}
\hline RESPONDENT & SEX & ETHNICITY & AGE & HoME REGION & $\begin{array}{l}\text { PROFICIENCY } \\
\text { IN } \\
\text { INDIGENOUS } \\
\text { LANGUAGES }\end{array}$ & PROFESSION \\
\hline 1 & F & Mansi & pensioner & $\begin{array}{l}\text { Mansi } \\
\text { settlement in } \\
\text { Oktyabrskiy } \\
\text { rayon }\end{array}$ & $\begin{array}{l}\text { native speaker } \\
\text { of Mansi }\end{array}$ & $\begin{array}{l}\text { language } \\
\text { professional }\end{array}$ \\
\hline 2 & M & Mansi & $\begin{array}{l}\text { middle- } \\
\text { aged }\end{array}$ & $\begin{array}{l}\text { Mansi } \\
\text { settlement in } \\
\text { Berezovskiy } \\
\text { rayon }\end{array}$ & $\begin{array}{l}\text { native speaker } \\
\text { of Mansi }\end{array}$ & artist \\
\hline 3 & F & Mansi & young adult & $\begin{array}{l}\text { settlement of } \\
\text { urban type in } \\
\text { Berezovskiy } \\
\text { rayon }\end{array}$ & $\begin{array}{l}\text { Mansi classes } \\
\text { at school }\end{array}$ & student \\
\hline 4 & F & Mansi & young adult & $\begin{array}{l}\text { settlement of } \\
\text { urban type in } \\
\text { aerezovskiy } \\
\text { rayon }\end{array}$ \\
\hline
\end{tabular}




\begin{tabular}{|c|c|c|c|c|c|c|}
\hline 5 & $\mathrm{~F}$ & Nenets & young adult & $\begin{array}{l}\text { Nenets } \\
\text { settlement in the } \\
\text { Yamal-Nenets } \\
\text { Autonomous } \\
\text { Okrug }\end{array}$ & $\begin{array}{l}\text { none; speaks } \\
\text { Russian only }\end{array}$ & student \\
\hline 6 & $\mathrm{~F}$ & Khanty & young adult & $\begin{array}{l}\text { Khanty } \\
\text { settlement in } \\
\text { Beloyarskiy } \\
\text { rayon }\end{array}$ & $\begin{array}{lr}\text { speaks a few } \\
\text { words } \\
\text { Khanty }\end{array}$ & student \\
\hline 7 & $\mathrm{~F}$ & Khanty & young adult & $\begin{array}{l}\text { Khanty- } \\
\text { Mansiysk }\end{array}$ & $\begin{array}{l}\text { none; speaks } \\
\text { Russian only }\end{array}$ & student \\
\hline 8 & $\mathrm{M}$ & Khanty & young adult & $\begin{array}{l}\text { Khanty } \\
\text { settlement in } \\
\text { Beloyarskiy } \\
\text { rayon }\end{array}$ & $\begin{array}{lr}\text { speaks a few } \\
\text { words } \\
\text { Khanty }\end{array}$ & student \\
\hline 9 & $\mathrm{M}$ & Mansi & young adult & $\begin{array}{l}\text { settlement in } \\
\text { Kondinskiy } \\
\text { rayon }\end{array}$ & $\begin{array}{l}\text { none; speaks } \\
\text { Russian only }\end{array}$ & student \\
\hline 10 & $\mathrm{~F}$ & Mansi & $\begin{array}{l}\text { middle- } \\
\text { aged }\end{array}$ & $\begin{array}{l}\text { Mansi } \\
\text { settlement in } \\
\text { Berezovskiy } \\
\text { rayon }\end{array}$ & $\begin{array}{l}\text { native speaker } \\
\text { of Mansi }\end{array}$ & media worker \\
\hline 11 & $\mathrm{~F}$ & Mansi & middle aged & $\begin{array}{l}\text { Mansi } \\
\text { settlement in } \\
\text { Berezovskiy } \\
\text { rayon }\end{array}$ & $\begin{array}{l}\text { native speaker } \\
\text { of Mansi }\end{array}$ & media worker \\
\hline 12 & $\mathrm{~F}$ & Mansi & $\begin{array}{l}\text { middle- } \\
\text { aged }\end{array}$ & $\begin{array}{l}\text { Mansi } \\
\text { settlement in } \\
\text { Berezovskiy } \\
\text { rayon }\end{array}$ & $\begin{array}{l}\text { native speaker } \\
\text { of Mansi }\end{array}$ & media worker \\
\hline 13 & $\mathrm{~F}$ & Mansi & $\begin{array}{l}\text { middle- } \\
\text { aged }\end{array}$ & $\begin{array}{l}\text { Mansi } \\
\text { settlement in } \\
\text { Berezovskiy } \\
\text { rayon }\end{array}$ & $\begin{array}{l}\text { native speaker } \\
\text { of Mansi }\end{array}$ & media worker \\
\hline 14 & $\mathrm{~F}$ & Khanty & young adult & $\begin{array}{l}\text { Khanty } \\
\text { settlement in } \\
\text { Beloyarskiy } \\
\text { rayon }\end{array}$ & $\begin{array}{lr}\text { speaks a few } \\
\text { words } & \text { in } \\
\text { Khanty } & \end{array}$ & artist \\
\hline 15 & $\mathrm{~F}$ & Khanty & young adult & $\begin{array}{l}\text { Khanty } \\
\text { settlement in } \\
\text { Beloyarskiy } \\
\text { rayon }\end{array}$ & $\begin{array}{l}\text { none; speaks } \\
\text { Russian only }\end{array}$ & artist \\
\hline 16 & $\mathrm{~F}$ & Mansi & pensioner & $\begin{array}{l}\text { Mansi } \\
\text { settlement in } \\
\text { Berezovskiy } \\
\text { rayon }\end{array}$ & $\begin{array}{l}\text { native speaker } \\
\text { of Mansi }\end{array}$ & $\begin{array}{l}\text { language } \\
\text { professional }\end{array}$ \\
\hline
\end{tabular}

Table 11. Table summarising the respondents' sociolinguistic data 
The small size of the Ob-Ugric community, the low number of Khanties and Mansis living in Khanty-Mansiysk, and especially the possibility of uncomplicated identification of the people in the study, as well as the political tensions surrounding the discussion of minorities and ethnic identity compel researchers to be even more careful than usual. Therefore, contrary to the general practice, I do not specify the age of the respondents, not even pointing out the decade, and instead of their home village and hometown, I name the rayon or region where their home settlement is located. I refer to each respondent with the numbers assigned to them in order of their participation in the study. (For more details about the respondents, see Table 11.)

\subsection{Responses}

Owning and wearing folk costumes generally does not play an important role in expressing ethnic identity, according to respondents. The reduced contemporary importance of folk costume is also indicated by alienating and distancing expressions. Respondent 11 used the term "ancient" to describe a Mansi robe that was made 40 years earlier, while Respondent 4 said people wore folk costumes only in "remote villages" like Saranpaul or Shchekurya. Meanwhile, some respondents emphasised the intimacy and protective role of folk costumes, Respondent 16 said that the wearer "immediately feels lighter, protected and safe", while Respondent 11 considers the national dresses to have protective power, "even if it is not worn every day but hangs in the closet."

Similarly ambivalent is the perception of the importance of traditional foods. Most respondents list them in the last third of the priority list, and Respondent 3 goes on saying that the Mansi do not have dishes but "just get it [what they need] from nature and that's it". At the same time, middle-aged Respondent 12 emphasised that in case of being unable to have fish from her home region, she could not satisfy her hunger, irrespectively of the amount of food consumed she would still feel that something was missing. Respondent 16 stated that anyone who was accustomed to eating fish and meat in their childhood would not give it up later either, while Respondent 11 emphasised the ritual significance of traditional foods when she said that no Russian food should be used during Mansi sacrifice or prayer.

Traditional music and dance appear to be of importance only to those working in the arts, probably because, besides a few exceptions, practicing instrumental music and dance have 
traditionally fallen under sacred prohibition for women. As Respondent 3 put it, "musical instruments were once forbidden to girls to touch, but now girls are taught how to play them, because girls are not considered women." The evaluation of knowledge about folklore is clearly positive, and its significance is close to the importance of language skills. According to Respondent 9, "culture can be known well without proficiency in the [indigenous minority] language", moreover, in his opinion, extensive knowledge of culture can motivate a person to learn a language, while Respondent 4 said that knowledge of culture was more important than language proficiency, because "language will disappear anyway", while knowledge of traditions may be essential "to enable one to follow the rules, what they allow and what they do not." Although the traditional religious practices have been expected to be evaluated as a very important identity marker, they were not prominent enough for respondents to comment their choice of categorisation, except for Respondent 11, who considered it necessary to note that her parents had adhered to religious standards very strictly, and although she has been living in Khanty-Mansiysk for twenty-five years, she continued to follow this family tradition and made her children join her as well.

Despite its prominent iconological role, the significance of fishing, hunting and reindeer herding is ambiguous in every respect. Some respondents attribute high importance to the traditional lifestyle, others leave it uncommented. According to Respondent 4, fishing and hunting, and especially reindeer husbandry, can be practiced only in the traditional KhantyMansi areas, but even there they require various licenses, and the permitted amounts of game and catch per capita make it almost impossible to base an exclusive livelihood on it. Likewise, the appreciation of fishing and hunting over reindeer husbandry or vice versa may differ among respondents. In general, hunting was considered more important by those who grew up as native speakers of Mansi, while reindeer husbandry was found to be more significant by students without a living connection to the Ob-Ugric cultural background. Respondent 9 for example stated that reindeer herding preceded hunting and fishing, because although the former lifestyle is similar to the latter, reindeer breeding is still "more attached to the Khanty-Manish ethnic culture".

The respondents' opinion about the traditional indigenous territories and traditional types of buildings is also controversial. Everyone attributes less significance to the appearance of the dwelling place than its location. Respondent 14 finds it very important to stay in contact with traditional Khanty territories because, this way, visiting these territories during the summer she could introduce traditional lifestyle to her children. (Even though she and her family visit a 
settlement hundreds of kilometres away from her home region, she attributes great importance to this opportunity.) According to Respondent 11, although living in a traditional area is synonymous with being Mansi, it still does not guarantee a deeper knowledge of the language or culture, since more and more people speak Russian in the countryside as well, while people living in urban settings may also be familiar with the traditions. Respondent 9 is even more flexible, saying that wearing a folk costume does not play a role in identity marking, because it can be worn by anyone; also being born and raised in the traditional territories have no significance, as this Respondent was born and raised in a traditional settlement as well, yet he does not have any information about Mansi language or culture.

At the time of compiling the questionnaire, regional, urban, and institutional events featuring indigenous participants to address the attention of a wider, non-indigenous audience were meant by participating in programs of indigenous minority organisations. The majority of respondents defined community programs in accordance with this concept, and only those attached any importance to participating for whom these events represented the only way to connect with the Ob-Ugric community. According to Respondent 4, it is difficult to get preliminary information about such events, and the programs themselves are irrelevant, while Respondent 11 expressed the opinion that such events are only suitable for maintaining an idealised image of the indigenous people, and she found that at such events Khanties were overrepresented, whereas the Mansi were very often overlooked.

Proficiency in the indigenous minority languages is a priority for most respondents, and it holds a preeminent place irrespective of their own language skills. Respondent 14 said that "anyone who does not speak the language is unable to understand the culture", while Respondent 16 simply stated that "if one wants to be a Khanty, a Mansi, one must speak the language". In their opinion, this regulation is binding irrespective of the place of residence, since, as with the knowledge of folklore and traditions, the knowledge of the language does not require "living in the woods".

According to the answers received, the significance of family and kinship in defining a person's ethnic identity is equivalent to the importance of proficiency in the indigenous minority languages. Having indigenous parentage was ranked second by Respondent 11 only because while she was using the language every day, she had not been in touch with her ancestors and relatives any more, since her parents had been deceased and her siblings have 
been living far away. Arguing for the importance of having indigenous ancestors and relatives, Respondent 4 outlined a situation quite typical for determining a person's ethnic identification:

Respondent 4: It is important to have indigenous people among your ancestors. Someone comes in, "Hello, I'm Mansi." "How come you are Mansi?" "Well, I don't know, everyone in my family is Russian, but I'm Mansi." For example, I'm Mansi. My mother is Khanty, my father is Komi.

CsH: Then how can you be Mansi?

Respondent 4: Because my maternal grandmother is Khanty, but my grandfather is Mansi. My paternal grandmother is Komi, but my grandfather is Mansi.

CsH: So that makes two of the four?

Respondent 4: Yes. And thus we are all Mansis. Still both [grandfathers] count as Russians. Officially. [...] One wants to learn the language, but it is impossible to find time for that. [...] My grandmother speaks Russian. She is speaking, suddenly she forgets about herself, keeps talking in Khanty for a long time and I understand nothing. [...] Me and my brother are Mansis, all of our cousins are Khanty. If I tell someone that I am Mansi, they are always surprised. For example, I go to dance classes with these girls. They are newcomers. [Respondent mocks the girls' voices:] "Khanty-Mansi!" [...] I tell them, hey, I am Mansi myself. "What do you mean you are Mansi? You people live here? But it's cold here!"

Respondent 14 questioned whether without her grandparents following the traditional lifestyle she would have become a Khanty herself, especially since her father was Russian, and she has been raised in a Russian environment, according to her poetic expression indigenous parentage was crucial, since with the help of this "the soul is calling".

\begin{tabular}{|l|r|r|r|r|r|r|r|r|r|r|r|r|r|r|}
\hline & $\mathbf{3}$ & $\mathbf{4}$ & $\mathbf{5}$ & $\mathbf{6}$ & $\mathbf{7}$ & $\mathbf{8}$ & $\mathbf{9}$ & $\mathbf{1 0}$ & $\mathbf{1 1}$ & $\mathbf{1 2}$ & $\mathbf{1 3}$ & $\mathbf{1 4}$ & $\mathbf{1 5}$ & $\mathbf{1 6}$ \\
\hline living in the traditional territories & 12 & 8 & 2 & 5 & - & 1 & 8 & 8 & 3 & 9 & 1 & 6 & 8 & 2 \\
\hline $\begin{array}{l}\text { living in a traditional type of } \\
\text { building }\end{array}$ & 13 & 8 & 6 & 5 & - & 1 & 9 & 12 & 3 & 10 & 3 & 7 & 8 & 3 \\
\hline reindeer breeding & 9 & 5 & 4 & 5 & 3 & 1 & 3 & 11 & 5 & 12 & 7 & 7 & 8 & 2 \\
\hline fishing, hunting & 10 & 5 & 5 & 5 & 3 & 1 & 5 & 9 & 5 & 11 & 7 & 3 & 8 & 2 \\
\hline
\end{tabular}




\begin{tabular}{|c|c|c|c|c|c|c|c|c|c|c|c|c|c|c|}
\hline $\begin{array}{ll}\text { practicing traditional } & \text { ritual } \\
\text { activities and customs } & \end{array}$ & 4 & 4 & 7 & 4 & 2 & 2 & 1 & 13 & 1 & 6 & 4 & 5 & 2 & 1 \\
\hline owning and wearing folk costumes & 8 & 7 & 6 & 7 & - & 1 & 6 & 7 & 1 & 3 & 8 & 2 & 6 & 3 \\
\hline knowing traditions and folklore & 3 & 2 & 1 & 3 & 1 & 2 & 1 & 4 & 2 & 5 & 5 & 4 & 4 & 1 \\
\hline preparing traditional food & 7 & 6 & 5 & 5 & 6 & 2 & 5 & 14 & 3 & 8 & 10 & 5 & 5 & 4 \\
\hline practicing traditional crafts & 6 & 4 & 6 & 6 & 4 & 2 & 3 & 10 & 2 & 7 & 2 & 6 & 8 & 3 \\
\hline $\begin{array}{l}\text { playing traditional music and } \\
\text { doing traditional dance }\end{array}$ & 5 & 4 & 3 & 3 & 3 & 2 & 6 & 3 & 4 & 13 & 12 & 4 & 7 & 4 \\
\hline $\begin{array}{l}\text { speaking the indigenous minority } \\
\text { language }\end{array}$ & 2 & 3 & 1 & 1 & 2 & 2 & 2 & 5 & 1 & 1 & 6 & 2 & 3 & 1 \\
\hline $\begin{array}{l}\text { having minority ancestors and/or } \\
\text { relatives }\end{array}$ & 1 & 1 & 8 & 2 & 1 & 1 & 4 & 6 & 2 & 2 & 9 & 1 & 1 & 2 \\
\hline $\begin{array}{l}\text { participating in the programs of } \\
\text { indigenous minority organisations }\end{array}$ & 11 & 9 & 2 & 8 & 5 & 2 & 7 & 2 & 5 & 14 & 11 & 5 & 9 & 4 \\
\hline motivation for learning & - & - & - & - & - & - & - & 1 & - & - & - & - & - & - \\
\hline transmitting knowledge & - & - & - & - & - & - & - & - & - & 4 & - & - & - & - \\
\hline $\begin{array}{l}\text { belonging to an indigenous } \\
\text { minority community }\end{array}$ & - & - & - & - & - & - & - & - & - & - & - & 1 & 9 & - \\
\hline
\end{tabular}

Table 12. Summary of the respondents' answers regarding the hierarchy of markers of indigenous ethnic identity

In addition to the significance of indigenous ancestors and relatives, Respondents 14 and 15 underlined the importance of the ethnic community and belonging to the group, so at their request I added this element to the list of indigenous identity markers. According to Respondent 14, only the retentive power of the ethnic community can make the other elements on the list to be realised.

Respondent 10 also linked the fulfilment of the other examined identity markers to the fulfilment of a preliminary prerequisite, namely, the individual's motivation and desire to learn.

"It all starts too far, and the whole foundation lacks the initial need, that first it is necessary to learn and to master abilities. You have to be interested in. These [elements in the list] are high, long-term goals that come only after interest and learning. Learning has to start very early, already in kindergarten." 
Respondent 1 did not attach great importance to any of the identity markers on the list, saying that their existence does not guarantee, their absence does not exclude anyone from being considered a representative of one of the indigenous minorities in the Okrug. In her view, the essence of the Mansi and Khanty character is "a kind of vulnerability, a sensibility" that she thinks to be appreciable even when an Ob-Ugric person lives far away from their family or region of origin, without knowing their language or culture. Respondent 2 found it important to mention similar spiritual notions, especially intra-family reincarnation and rebirth, he found these more important guarantees of Mansi identity than any of the listed identity markers.

\subsection{Summary}

I have investigated the relative significance of Arctic indigenous ethnic identity markers in a study carried out in December 2018 and in March and April 2019. Eventually, I was able to collect sixteen respondents' responses. During the periods of fieldwork carried out in the Khanty-Mansi Autonomous Okrug, the consultants' interest in participating in the research was the lowest during the time of this last study. I explain people's rejection of both responding and giving permission to record the responses with the recent changes in the socio-political environment and the resulting general mistrust.

Based on the responses received, we may conclude that the markers of intangible indigenous identity are more important than markers related to material culture, and the positions of translocating identity markers are more stable than those expressing non-urban ones, although lifestyle and place of residence are still enshrouded by a certain nostalgia and an idealised approach. The results show that the use of indigenous minority languages is a characteristic and important element of the expression of ethnic identity and language, the perception of proficiency in indigenous languages is high, irrespective of the respondent's proficiency, yet competence of Khanty or Mansi is not a crucial or exclusive criterion of indigenous identity.

From the point of view of defining ethnicity and ethnic identity, descent or parentage is of approximately equal importance to the use of language, and most opinions and personal stories are related to its significance or to the misidentification of ethnicity. This may be due to the fact that the question of ethnicity and the difficulty of establishing one's ethnicity have been 
a part of the everyday life of indigenous minorities in the North since the advent of nationality administration. 


\section{The Lylyng Soyum Centre}

The Mansi language has been taught in various types of educational institutions in the territory of the Khanty-Mansi Autonomous Okrug, from kindergarten to university. A distinction can be made between state supported and alternative institutions. The former are financed by the state, at the federal level, the latter are based on non-governmental initiatives and financed by the Department of Indigenous peoples of the Khanty-Mansi Autonomous Okrug. According to official statistics, in 2011 there were ten schools teaching Mansi in the Khanty- Mansi Autonomous Okrug, three of them were completely or partially operating with preschool classes. It is very important to note that neither in the city of Khanty-Mansiysk nor in other major cities of the Okrug do state supported schools, preschools offer Mansi classes. Even the Department of Mansi Studies at Yugra State University was temporarily closed in 2010. (More data on Mansi education in chapter 8.6.)

\subsection{Educational institutions}

\subsubsection{State schools}

In state supported schools with an ethnic profile (икольл $c$ этнокультурной составляющей образования in Russian), the indigenous minority language is a subject taught in grades 1-9 and optionally in grades 10 and 11. The teaching of Mansi is threatened by various difficulties, one of which is the insufficient number of well-trained teachers. In the Okrug, there are about 560 indigenous persons who have university degrees (Horváth 2010a: 17), 25\% of them live in Khanty-Mansiysk, and altogether $60 \%$ in urban settlements, while the majority of state supported schools with an ethnic profile are situated in small villages in the countryside.

The range of Mansi-related courses and subjects offered by state education is quite narrow. As opposed to earlier periods in the history of Mansi education, when other subjects, for example mathematics used to be taught in Mansi, now only Mansi language classes are available for the students.

According to the results of participant observation and the consultants' reports, the teaching methods used in state schools do not change between the primary school and the 
university level. Language classes are organised in small group sessions (according to official statistics, the number of the students studying Mansi in one class never exceeds 10), there is no ground left for individual work or individual sessions. The classes are focused on the Mansi language only (that is, on grammatical features, vocabulary, and short stories covering the traditional lifestyle, but historical aspects, modern life or the majority society are rarely mentioned), and they follow the original or the revised versions of old-fashioned Mansi schoolbooks. Both the teaching methods and the teaching materials are building on the previous knowledge of the Mansi language and culture that the students supposedly have, and there are only a few recent examples providing teaching materials to assist heritage or second language learners as well, such as the summary of grammatical features and suffixes (Герасимова 2004) or the vocabulary list of lexical items (Афанасьева - Акбаш 2007) which students should be able to confidently use by fourth grade. During the classes the teachers use frontal teaching methods, it is the teachers who explain and present the topic of the day, and make the students absorb the new information through exercises, usually by translating phrases from Russian to Mansi. Students rarely need to compose texts in Mansi on their own, or to converse freely in Mansi.

The Office of Educational Development started to organise non-curricular campaigns to raise the activity of native speaker and heritage language leaner children as well as to propagate Mansi language education. Since 2016 schools with ethnic profile and institutions with Mansi profile have started to participate in the all-Russian campaign "Dictation in the mother tongue" (Диктант по родному языку in Russian). During the event Mansi speakers gather at designated institutions and try to write down a Mansi text read out aloud with making the fewest possible mistakes. Since 2016 the Office has requested that schools with an ethnic profile celebrate the day of native languages by making short videos in the Khanty or Mansi language.

\subsubsection{Alternative education}

In some larger, urbanised settlements with a considerable Mansi population, alternative educational institutions have been founded in order to complement Mansi children's knowledge of their heritage culture and the Mansi language which they could not acquire within their family. Alternative educational institutions, that is, institutions offering extracurricular courses (officially recognised as children's institutions of "additional education", учреждение 
дополнительного образования детей in Russian) teaching the Mansi language and culture currently exist in two settlements in the Khanty-Mansi Autonomous Okrug, in Saranpaul and in Khanty-Mansiysk. Both schools welcome children of all ethnic groups, but their main aim is to convey the knowledge and skills which are necessary for constructing an Ob-Ugric identity. Alternative institutions start to enrol children from the youngest age possible (that is, in accordance with the law, from age 4) and offer a full range of courses introducing different aspects of Mansi life, such as instrumental music, folk dance, handicraft, national sports, and the Mansi language. These institutions are also financed by the Russian state, partly at the regional level, and partly through various grants.

These institutions were established to train students with limited or no knowledge of Mansi culture and no competence in the Mansi language at all. They attempt to find a solution for the problems state schools have faced for decades, and they do so by developing new teaching materials (cf. section 10.5) and teaching methodology (cf. section 10.6).

\subsection{The history of the Lylyng Soyum Centre}

The idea of founding an institution of extracurricular courses in Khanty-Mansiysk goes back to the founding director of the Lylyng Soyum Centre (Лыльly со̄юм 'living creek' in Mansi), Tatyana Khozyainova (then Vadichupova) in 1998. Teaching in one of the elementary schools of Khanty-Mansiysk, she noticed that not only the majority students, but also the students of Mansi and Khanty descent were completely unaware of the basic characteristics of Ob-Ugric cultures and languages. Since there were no schools, classes or educational programs specially designed to introduce the indigenous people to the students in public education, she decided to start a children's education centre to help local Khanty and Mansi children maintaining their indigenous identity, and to learn about Ob-Ugric languages and cultures.

The Lylyng Soyum Centre (full name is Russian: Детский этнокультурнообразовательный цеентр «Лылынг Союм») opened in 2003 with approximately 25 students. The courses were held in a two-room apartment on the outskirts of Khanty-Mansiysk, but after a few years the Centre was given an opportunity to move to the city centre, to its present headquarters where they were allowed to house roughly 60 students at a time. The Centre is now operating seven days a week, from 8 AM to 6 PM between 4 and 8 with teachers in charge. 
In 2012, the Centre created a plan in order to raise a new building for the Centre, and subsequently to expand the number of teaching programs, aiming to start a full range of educational programs from preschool to secondary school. Although the Centre received promises from the government, this plan was never realised. In 2015 the Centre was given the basement flat below the already operating office, thus the Centre was able to double its floor area as well as the number of students attending classes there. In 2018, even though it was not provided a separate school venue, the Centre decided to start an experimental class of eight first-graders. Instead of attending certain courses organised by the Centre, the experimental class is trained according to a full curriculum. Also in 2018 the decision of the regional government put an end to a longstanding dispute regarding the sign placed at the main entrance of the Centre. Being a non-commercial institution, the Lylyng Soyum Centre was not allowed to use a sign featuring any other language than Russian, subsequently in 2019 the sign was removed and the expression Lylyng Soyum was deleted from the name of the Centre. Although in official documents the Centre uses its legal new name (МБУ ДО «ДЭКОЦ»), in colloquial conversation the Centre is still referred to as the Lylyng Soyum Centre. Roughly at the same time, the founding director of the Centre T. S. Khozyainova was removed from her position and was appointed as methodology advisor.

10.3. Teachers and students at the Lylyng Soyum Centre

Every teacher working at the Centre has teaching credentials. Since its foundation, the Centre has employed about 15-20 teachers. Courses related to Khanty and Mansi languages and cultures are taught by $\mathrm{Ob}$-Ugric teachers raised as native speakers of the languages in question. Currently there are three Mansi teachers working at the Centre, two of them stated to feel it easier to express themselves in Russian, while the third teachers speaks both languages with equal ease. Their parents speak Mansi as their mother tongue, their older siblings speak Mansi and Russian, and their younger siblings speak almost only. One of them, Consultant 35 has a Tajik spouse with whom they speak Russian, their children's first language is also Russian, but the latter claim to understand the mother tongue of both parents. The Mansi teachers at the Lylyng Soyum Centre finished primary school at their respective home villages, speaking Russian during classes and Russian together with Mansi during breaks. 
There are no official statistics available on the students of alternative institutions, but according to the estimation of the teachers working at the Lylyng Soyum Centre, approximately 580 students attend the classes provided by the Centre, 180 of them going to the Centre, while the rest of the students meet visiting teachers in their own institutions. While originally it was mainly the children of Ob-Ugric intellectuals who started to attend the courses, thanks to the successful advertising of the programs and their good reputation, the Centre has more students applying than they can admit. The Centre has a very liberal policy about the admission of students: they accept any children regardless of their ethnic background or cultural knowledge. The courses are free of charge, the only solution for managing the constant demand for more places for new students is to register children's absences: children missing three classes in a row are kindly asked to leave and give their spots to other students.

There is no information available on the children attending courses outside the Centre. The students visiting the Centre represent various age and ethnic groups. The vast majority of them are aged 6-12, approximately $25 \%$ are of kindergarten age, while teenagers form a minority among them. The sex ratio is balanced among 6-12-year-old students, while the majority of kindergarten and teenager students are girls. The Centre keeps no records of the students' nationality, thus only occasional information is available about it, when teachers or the students themselves make reference to the issue during conversation. According to these references, many of the children have one Khanty or Mansi parent, also many of them have no Ob-Ugric parentage, but partly belong to immigrating minority ethnic groups. Occasionally the nationality of both parents has been revealed, for example children coming from Mansi-Tajik, Mansi-Kumyk, or Russian-Kazakh families were mentioned.

\subsection{Subjects taught at the Lylyng Soyum Centre}

The exact number and choice of courses offered by the Lylyng Soyum Centre varies in accordance with the location of the Centre and the teaching staff available at the time, but the list of the core subjects have remained unchanged over the years. The most popular courses, attended by almost every student of the Centre, are classes in beading, traditional handicraft (e.g. birch bark handicraft), traditional instrumental music, dance, and language classes.

The teaching staff of the Centre adapted a technique for the popularisation of the courses. While vising preschools, the teachers aim to reach the youngest children by advertising 
the beading and instrumental music classes. Children can be easily attracted by the colourful ornaments and jewellery made of beads, as well as the exotic indigenous musical instruments. During the handicraft and music classes the teachers find a way to say a few words about various aspects of Mansi and Khanty culture, to introduce Mansi and Khanty terms to describe special characteristics, thus familiarising children with Ob-Ugric languages. According to teachers' reports, almost every child who has attended handicraft or music classes later joins the language courses as well.

The Lylyng Soyum Centre offers various types of languages courses. As far as the Mansi language is concerned, children younger than school age attend the beginners' class called Vitsam, while older children attend Mansi classes according to their level of proficiency. The size of classes may vary between one and ten children. The children attending the language courses usually have no prior knowledge of Mansi.

\subsection{Teaching materials at the Lylyng Soyum Centre}

Until the 1980s, the primary school was generally the first environment in which Mansi children were confronted with the supremacy of the Russian language and Soviet culture. The aims of the school were to make students literate in their indigenous minority mother tongue, to make them acquire the Russian language, and to assimilate them into Soviet society. The schoolbooks were clearly designed to serve these three purposes. The Mansi primers and textbooks (е.g. Баландин 1964, Zuḷov 1933) were aimed at native Mansi speakers as they did not use another language as a means of instruction. In lower classes the textbook materials focused on the terminology of traditional lifestyle, avoided neologisms and tended to overuse Russian loanwords. The textbooks were also loaded with heavy political content. Besides the usual topographic descriptions and animal stories, the books contained information about the Soviet state, its administration and its citizens' duties as well as stories aiming to intensify patriotic feelings. Texts for Victory Day, Labour Day, and the Day of the Red Army were to be found in each and every Mansi textbook, along with texts about the little Octobrists' and pioneers' duties, Lenin's (in earlier schoolbooks: Lenin's and Stalin's) biography etc.

The next generation of Mansi textbooks, published after the collapse of the Soviet Union (e.g. Сайнахова 2001) seem to have a very similar structure and range of topics, which is not surprising, since these books are often merely newly edited versions of the Soviet books. The 
editing process has not brought many changes beyond the ideological ones: directly political texts have been replaced with new chapters about oil production. Thus, these Mansi textbooks consisted of short introductions into urban life and the modern environment, as well as detailed descriptions of the traditional lifestyle and Arctic flora and fauna. These books may have been more useful in schools of small Mansi settlements but were not very attractive for those students studying Mansi who were born and raised in urban settlements: these children would have required more detailed vocabulary for urban life, and for them not only the Mansi but also the Russian words for Arctic flora, fauna and livelihoods (such as reindeer breeding) were unknown.

Reacognising the shortage of Mansi textbooks and teaching materials meeting the needs of heritage language learners, the Lylyng Soyum Centre started to produce its own series of textbooks, though so far only a Mansi primer (Норова 2010) and an accompanying handbook for teachers (Норова 2011) have been published. In language classes printed materials are supplemented with Power Point presentations and handouts with short poems for the easier memorisation of new vocabulary, as for example, the following kinship terms:

$\begin{array}{ll}\text { Моя семья - колтагыл } & \text { My family, that's koltagyl } \\ \text { Апщи - братик для меня. } & \text { apshi, that's my little brother } \\ \text { Увщи - старшая сестра } & \text { uwshi, that's the older sister } \\ \text { Йигирищ - сестренка } & \text { yigirish [sic!] is the little sister } \\ \text { Самый старший у нас брат, } & \text { my brother is the oldest of us } \\ \text { По мансийски значит - канк. } & \text { in Mansi he is called kank [sic!]. }\end{array}$

In Soviet times, primers and textbooks usually came with different kinds of accompanying handbooks or booklets. In most cases these booklets merely contained the Russian translations of the texts (е.g. Чернецов 1933), but for some books, very detailed instructions (Ромбандеева 1960) were available which providing the teacher with complete lesson plans. For example, first grade students were supposed to practice the "quick and proper composition of sentences" according to the following guidelines: 
Учитель: Лавен, туйт тэли ма магыс, йивыт магыс ёмас ман люль? (Скажите, хорошо ли, что земля и деревья покрываются снегом?) Дети: Тэли ма йивыт туйтн лап-туявет, сака асирма атим. Тэли туйт тармыл суныл, ёсал яласаукве ёмас. Ворт хуйнэн порат туйтыл рахматэгн, асирмау атим. (Зимой земля и деревья покрываются снегом, не очень промерзают. По снегу зимой хоромо ездить на нартах и лыжах. Во время ночевок в лесу забираешься под снег, не холодно.) (Ромбандеева 1960: 8)

"Teacher: Tell me, is it good or bad for the earth and trees to be covered with snow? Children: In winter the earth and the trees are covered with snow, it is not very cold [for them]. It is very good to travel on the snow with a sledge or on skis. If you hide under the snow when you have to spend a night in the forest, it will not be cold."

The teacher's handbook to the new Mansi primer for alternative education emphasises the importance of using other teaching methods than the frontal model, and it regards the Mansi language as an inseparable part of Mansi culture. The booklet does not explicitly deal with the issues of bilingualism or language shift, with the exception of a brief remark on the decreasing number of young speakers. The teachers' booklet states that the aim of the educational program is to raise children's interest towards learning Mansi by introducing them to various kinds of decorative art, as well as literature and folklore (Норова 2011: 4). Moreover, the aim, as defined in the handbook, is that the children understand Mansi speech by the end of the preschool curriculum (Норова 2011: 6, 22), which means that alternative schools do not count on any knowledge of the Mansi language brought from the family.

10.6. Teaching methods at the Lylyng Soyum Centre

Recognising the sociolinguistic status of heritage language learners, the teachers working at the Lylyng Soyum Centre proceed towards the acquisition of Mansi only very slowly, step by step. The teachers are aware of the fact that a child bilingual in Russian and Mansi is more of an exception than the norm, thus, they do not require prior knowledge but aim to raise the children's interest in the Mansi language and culture at the earliest age possible, that is, preferably at preschool age. 
The teaching methods used in alternative educational institutions are more diverse than in the state schools, the teaching of language and culture is embedded in life-like social practices rather than classic school classes. Teachers follow the traditional methods used in Mansi society: they let the students start their learning process by observation, then to try their skills by themselves, and finally the teacher or a tutor joins the student to perfect their skills together. Teachers pay attention not to separate the language from the culture, or traditions from contemporary life. Besides running the tutoring system, they also frequently invite "elders", famous Mansi and other local indigenous artists, professors, and indigenous intellectuals to speak to their students. Teachers try to pay equal attention to the traditional as well as the urban lifestyles. Classes are often held outside the classrooms, on these occasions the students visit local parks and museums. The alternative educational institutions strongly emphasise the importance of living an environmentally friendly life both in rural and urban settlements, they also celebrate the annual Day of Finno-Ugric peoples, or use symbols that remind students of the linguistic relationship: for instance, the tree-shaped setting depicting the Finno-Ugric language family is displayed in the largest hall of the alternative school in Khanty-Mansiysk.

Students can enrol in Mansi language classes suitable for their age and level of proficiency, and, most importantly, the Lylyng Soyum Centre is ready to run a class even for one student, while state education makes language classes available only in the case of a certain number of enrolling students. Alternative schools are pioneers in switching to the use of a revised orthography, which is easier to read for second language learners, and which is consistent with the orthography used by the press and other media.

10.7. The role of the Mansi language in the curriculum of the Lylyng Soyum Centre

Despite of its Mansi name, the Centre concentrates on both Ob-Ugric peoples, employs both Mansi and Khanty teachers, accepts both Mansi and Khanty students, and offers both Mansi and Khanty language courses. Still, the Mansi part of the profile seems to be slightly more dominant. The contacts with other cultural and educational institutions and the most defining people working in and around the Centre also strengthen its position in the maintenance of Mansi language and culture. 
Since the Lylyng Soyum Centre is the only educational institution aiming to revitalise the Mansi languages among children in Khanty-Mansiysk, the specialists of the Centre found it necessary to find partners in the traditional Mansi speaking territories of the Okrug. The Centre is in close and regular contact with the Mansi educational program of Saranpaul (a large village in the same Okrug) called "Sali lyongkhyt" (Са̄льı лёухыm, 'reindeer's trail' in Mansi). The director of the Saranpaul school, Dmitriy Ageev was the mentor of some of the Centre's teachers when they spent their childhood in Saranpaul, and the students from both schools make annual visits to each other to carry out projects together.

The other professional contact that greatly defines the work at the Lylyng Soyum Centre is the summer camp called Many Uskve (Мань Ускве, 'little town' in Mansi), organised during the summer holidays. Mansi children have the opportunity to spend one or two weeks in a traditional Mansi camp, in the foothills of the Urals. Besides focusing on the central topic of the camp session in question (the usual handicraft and language courses, as well as sports and “youth politicians' debates"), the summer sessions aim to raise the children's awareness of environmentally friendly lifestyles.

The Mansi teachers working at the Lylyng Soyum Centre take an active part in the creation of Yugorika, a series of short Mansi video lessons, published by the local television and archived online (cf. Chapter 9.8)

\subsection{Achievements}

\subsubsection{Aims}

The Centre never aimed to raise bilingual Mansi-Russian speakers or even to provide a domain of Mansi language use, the official goals were to study and use the culture, ethnic art and handicraft of the Ob-Ugric peoples, to promote the cultures and languages of the Ob-Ugric peoples and to raise children's interest towards them, to provide education for them and to provide a venue for carrying out further projects initiated by young specialists in the same fields.

\subsubsection{Results}


The teachers teaching Ob-Ugric languages and elements of the Ob-Ugric cultures at the Centre were raised in the language and culture they are promoting. Besides that, they also have the necessary qualifications to teach these classes, they generally hold degrees of St. Peterburg or Novosibirsk pedagogical colleges. In addition, the teachers regularly organise or participate in handicraft workshops to disseminate their knowledge and to master a new type of folk art. The language teachers regularly attend seminars, as well as the "Teacher of native language of the year" contests, where they have to present a teaching plan and hold a demonstration lesson, and where their work is evaluated by well-qualified specialists.

The various experimental teaching methods applied at the Lylyng Soyum Centre have been introduced gradually and have been in use for just a short period, thus, their long-term results are difficult to evaluate yet. It is already obvious that advertising and teaching methods used at and by the Lylyng Soyum Centre are suitable for making the Mansi culture attractive for urban children and adults. The promotion of the programs reaches a large number of children in town, and raises their (and their parents') interest in the courses. The student-centred attitude of the teaching methods does not only require active participation on the part of the students but also makes them willing to do so, since the methods position teachers and students as equal partners, engaged in the teaching/learning process to the same degree. Following these principles, the teachers let the students improvise during the process of learning and performing.

Regarding Mansi language education, the Lylyng Soyum Centre uses its complete range of financial, human and professional competencies and resources to create the only continuously operating institution providing Mansi language courses as well as to cooperate with any other institutions motivated to act similarly. Despite the different social settings and ideological and methodological backgrounds, state and alternative educational institutions face some of the same problems. Coping with them, the system of state education appears to be more established but less innovative: it follows its traditions as if the main task of public education were still the students' submersion in the Russian language, as it was during the Soviet era. The teachers working in state education still tend to use the old-fashioned teaching materials and teaching methods and do not seem to be interested in the maintenance of the Mansi language (as far as the problems of language acquisition and of the narrowing domains of language use are concerned), neither do they treat Mansi as a living, usable, modern language with a functioning culture. 
Alternative education, on the other hand, recognises the contemporary problems concerning language acquisition and attempts to find solutions using experimental and creative teaching methodologies. The teaching methods used in alternative education treat the Mansi language as a heritage language and teach it as a second/foreign language, additionally, making the Mansi language and culture attractive for students. Teachers pay special attention to communicative skills in addition to exercises and achieve better results in urban settings than state supported education. Regional agencies maintaining Ob-Ugric languages and cultures support them in their initiatives and try to implement the Centre's experiences in state supported education as well.

The Centre as an institutions and the teachers of the Centre individually participate in various projects maintaining the Ob-Ugric cultures and languages in town. In 2018 the Centre gave place to Consultant 28's experimental class project and started to educated a class of eight children according to a fixed curriculum. Two of the Mansi teachers working at the Centre participated in the recent creation of a digital Mansi folklore anthology for children («Древо мудрости» манси).

\subsubsection{Outlook}

Khanty language nests were opened in the villages of Kazym (Onblm XMAO...) in 2005 and Tegi in 2012 («Языковые гнезда» для...). While plans of opening a Mansi language nest in the village of Shchekurya were announced in 2015 (Рещетникова 2015), and the operation of a Mansi language nest was reported in Saranpaul (Onbım XMAO...), Sosva and Nyaksimvol (Маленькие югорчане...) in 2016, no consultant mentioned any operating Mansi language nests, either in connection with or independent from the Lylyng Soyum Centre. In 2018, 1,139 preschool students and 7 teachers participated in language nest projects in the Okrug (Маленькие югорчане...). Based on the example of the Khanty and Mansi initiatives, a Yukaghir language nest has been opened (В городе Якутске...), and idea of creating Forest and Tundra Nenets language nests has emerged, in the Yamal-Nenets Autonomous Okrug (Чтоб родной язык...) as well as in the Nenets Autonomous Okrug (Проект «языковое гнездо»...).

The aims of the language revitalisation project of the Khanty-Mansi Autonomous Okrug entitled "Language Nest" were to help children to acquire the indigenous language and to use 
two languages in everyday life (Onbim XMAO...). The local specialists would prefer to create a set of languages nests focusing on local dialects over the creation of the literary standard variety which would be promoted through the classic educational system (Чтоб родной языкк..), but they are also aware of the fact that the authorities are not fond of the adaptation of the language nest model (Необходимо вернуться...). This may explain the tendency that although between 2009 and 2012 the Lylyng Soyum Centre in Khanty-Manysiysk was referred to as a language nest in conversation, no written mention of it as such is to be found.

Still, not calling the Lylyng Soyum Centre a language nest is a good decision, taking into account the fact that it is not present as a mere locus of language maintenance, but giving ground to initiatives aiming to expand the domains of language use it is undoubtedly a language revitalisation institution. At the same time, being unable to noticeably increase the number of Mansi speakers, and, above all, not using Mansi as the language of instruction and conversation, it definitely could not qualify for the title of language nest.

There is a demand for more constant and more detailed language teaching in KhantyMansiysk, requested by the parents of upper-grade students, by university students, and by young Mansi adults, any other teaching material and personnel, than textbooks for lower grades and teachers qualified for teaching children of age 5-10. In the case of more ideal conditions, that is, having Mansi textbooks for teenagers or for adult language learners, as well as having language teachers capable to teach such classes, if it were possible to carry out more intensive language education in Khanty-Mansiysk, changing the status of young parents and future young parents who wish to become heritage language learners, but have no opportunity to do so.

Turning the Centre into a language nest or an educational program based on language immersion would be highly problematic. There definitely are middle-aged and elderly speakers living in Khanty-Mansiysk who could be suitable instructors in these programs. At the same time, it is uncertain whether they would volunteer or participate in such programs, as it is also questionable whether the Lylyng Soyum Centre would be politically authorised to run or to house initiatives like these. Thus, starting a language nest or immersive learning program in the Centre now or in the near future is highly unrealistic. Yet, it is worth noticing that immersionlike programs have already been held at the Centre, for example, in 2015 a sewing group operated twice a week, which at the same time served as Khanty-speaking sewing club, where no use of the Russian language was allowed. 


\section{Conclusions}

\subsection{General conclusions}

This dissertation describes the situation of the Mansi language in Khanty-Mansiysk. Besides introducing the demographic circumstances and the institutions of Mansi profile, the role of the Mansi language in the linguistic landscape of Khanty-Mansiysk and the construction of ethnic identity of the Mansi living there are discussed also. The dissertation focuses on the analysis of possibilities of language acquisition and language use, and a separate chapter describes the revitalisation attempt carried out at the Lylyng Soyum Centre.

To illustrate the political background of the institutions and decisions mentioned in the previous chapters and the correspondence between them, the chart (Table 13) lists the events influencing the situation of the Mansi language vitality in Khanty-Mansiyk in chronological order, organised around the activity of the Lylyng Soyum Centre. On the two ends of the spectrum stand the governmental and non-governmental initiatives aiming to support the maintenance of Ob-Ugric languages and cultures. By governmental decisions those decisions are meant which may have been taken on federal or regional budgets but certainly represent top-down initiatives. Until 2010 these decisions were rather made at the regional level, while after the inauguration of the present governor these decisions - even if taken at the regional level - follow federal initiatives. By non-governmental decisions those initiatives are meant which may eventually receive temporary or constant financial support from the government, were demanded by private individuals or by one of the already existing institutions of Mansi profile.

\begin{tabular}{|c|l|l|l|}
\hline 1987 & GOVERNMENTAL DECISIONS & LYLYNG SOYUM CENTRE & NON-GOVERNMENTAL DECISIONS \\
\hline is opened & $\begin{array}{l}\text { Torum Maa open-air museum } \\
\text { puima Seripos is first } \\
\text { pulished }\end{array}$ & & \\
\hline
\end{tabular}




\begin{tabular}{|c|c|c|c|}
\hline 1992 & $\begin{array}{l}\text { The local branch of Russian } \\
\text { state television starts to } \\
\text { broadcast Mansi TV program }\end{array}$ & & \\
\hline 2002 & $\begin{array}{l}\text { The theatre of Ob-Ugric } \\
\text { peoples is opened }\end{array}$ & & \\
\hline 2003 & $\begin{array}{l}\text { The Department of Mansi } \\
\text { philology opens at Yugra } \\
\text { State University }\end{array}$ & $\begin{array}{l}\text { The Lylyng Soyum Centre } \\
\text { opens }\end{array}$ & \\
\hline 2005 & & $\begin{array}{l}\text { The Lylyng Soyum Centre } \\
\text { opens its own institution }\end{array}$ & \\
\hline 2010 & $\begin{array}{l}\text { The Department of Mansi } \\
\text { philology is closed }\end{array}$ & $\begin{array}{l}\text { The Lylyng Soyum Centre } \\
\text { starts to publish its own } \\
\text { teaching materials }\end{array}$ & \\
\hline 2011 & & $\begin{array}{l}\text { The Lylyng Soyum centre } \\
\text { starts to cooperate in } \\
\text { publishing Mansi } \\
\text { language teaching videos }\end{array}$ & \\
\hline 2012 & & & $\begin{array}{l}\text { The first issue of the Mansi journal } \\
\text { for children is published }\end{array}$ \\
\hline 2013 & & & $\begin{array}{l}\text { The Office of Educational } \\
\text { Development starts to publish } \\
\text { experimental teaching materials }\end{array}$ \\
\hline 2014 & & & $\begin{array}{l}\text { The students of School \#1 demand } \\
\text { Mansi classes } \\
\text { The first Ob-Ugric graffiti appear }\end{array}$ \\
\hline
\end{tabular}




\begin{tabular}{|c|c|c|c|}
\hline 2015 & & $\begin{array}{l}\text { The Lylyng Soyum Centre } \\
\text { doubles its facilities }\end{array}$ & \\
\hline & & & $\begin{array}{l}\text { The Office of Educational } \\
\text { Development starts to organise } \\
\text { Dictation in Mansi }\end{array}$ \\
\hline 2018 & $\begin{array}{l}\text { The Lylyng Soyum Cente is } \\
\text { refused the use of a Mansi } \\
\text { phrase in its name }\end{array}$ & $\begin{array}{l}\text { The Lylyng Soyum Centre } \\
\text { starts an experimental } \\
\text { class }\end{array}$ & $\begin{array}{l}\text { The Office of Educational } \\
\text { Development propagates Mansi } \\
\text { language use in video sessions }\end{array}$ \\
\hline 2019 & $\begin{array}{lr}\text { Specialisation of Khanty } \\
\text { philology is opened at } \\
\text { Nizhnevartovsk } & \text { State } \\
\text { University } & \end{array}$ & & $\begin{array}{l}\text { The first Mansi rapper moves to } \\
\text { Khanty-Mansiysk to publish his } \\
\text { first album }\end{array}$ \\
\hline
\end{tabular}

Table 13. Lists of the events influencing Mansi language vitality in Khanty-Mansiyk in chronological order

It is clearly visible that the governmental decisions until 2010 favoured to open new institutions, thus at the same time new domains of maintaining Ob-Ugric languages and cultures at a regional level, while after 2010 they appear to limit the productivity of previously created institutions and domains. Also, the governmental decisions seem to aim moving the centre of Ob-Ugric language education from the capital. Disregarding these tendencies, the Lylyng Soyum Centre seems to prosper, keeps housing new initiatives, and serves as the inspirer of Ob-Ugric language attitudes and language use in Khanty-Mansiysk, as is reflected in the appearance of non-governmental initiatives and decisions made at the regional level following the work taking at the Lylyng Soyum Centre. The activity of the Lylyng Soyum Centre almost exclusively affects language maintenance and language revival at the urban level, while the non-governmental initiatives, just as the governmental ones, affect the whole Okrug.

11.2. The situation of Mansi language vitality prior to the revitalisation attempts

The vitality of the Mansi language in the domains of language use in Khanty-Mansiysk was rather limited prior to the advent of revitalisation initiatives. The Mansi language occupied 
its strongest position in family language use and language teaching. However, since interethnic marriages and thus the use of Russian as a family language became widespread in KhantyMansiysk, and since the Mansi language was only present in higher education in KhantyMansiysk, this strong position could only be interpreted relatively. These two domains of language use were incapable to extend or to maintain the language use, and thus the language vitality of the Mansi language.

The Mansi language in Khanty-Mansiysk showed up in typically urbanised domains of language use, where it could not have otherwise been found in a non-urban environment. Such domains are the Mansi press, media, as well as entertainment (in the case of Mansi, this means theatre performances), public events (events, celebrations, and conferences). The fact that the Mansi language appeared in the above-mentioned domains of language use before revitalisation efforts could take place, resulted only in the numerical expansion of domains, while at the same time it did not have a lasting positive effect on language vitality. There either had been too few permanent language users (as in the case of the Mansi press and media) present at the domains, or the domains had been accessible only sporadically (as in the case of theatre performances and community events), thus although these urban domains proved to be suitable for raising the prestige of the Mansi language, they could not be fixed as permanent domains of language use.

\subsection{Mansi language revitalisation attempts in Khanty-Mansiysk}

Due to its unique importance and central role among the initiatives aiming to revitalise the Mansi language in Khanty-Mansiysk, it is necessary to highlight the activity of the Lylyng Soyum Centre. The demand to establish the Lylyng Soyum Centre arose when the Ob-Ugric intellectuals living in the city in the late 1990s were confronted with the fact that there were no educational centre or other institutions helping Ob-Ugric children to discover or preserve their ethnic identity, to acquaint them with Ob-Ugric languages and cultures. To change the situation, the Centre's founding director began to plan the foundation of a children's studio in 1999. The founding staff of the Centre realised that the continuity of intergenerational transmission of the indigenous ethnic culture is disappearing, since the conditions necessary for the maintenance are absent in the urban settings. The Centre was founded in order to restore this continuity, to provide a shelter aiming to revitalise Ob-Ugric cultures and languages. The Centre opened its 
gates to 25 children in 2003 , then operated with 60 , while by 2015 , some 580 students were attending the Centre's courses across the city, thanks to educational activities outside the Centre.

The Mansi language has been included in the program of the Lylyng Soyum Centre since the very beginning. The Centre places special emphasis on linguistic and cultural socialisation, beginning at the lowest possible age, since 2012 children aged four to five have been admitted to study at the educational programs. The Mansi language has been taught in two groups since 2009: for pre-school children, twice a week, in groups of 10-15, and for schoolchildren, once a week, in groups of 5. The structure of the Mansi language classes is diverse, beside classroom education it covers excursions around the city and forest walks, visits to ethnographic, cultural and leisure facilities, schools and preschools in the city. During language teaching, the Centre's staff avoids the use of otherwise common, drill-like, frontal teaching methods, instead they teach the Mansi language through experience-based communicative practices. Classes for the preschool group always include handicraft activities as well. There are several significant differences between the operation of public and alternative educational institutions: while in public educational institutions the language is typically taught by lecturers with academic degrees, the Lylyng Soyum Centre employs lecturers with teacher's degrees.

In the course of a few years the Lylyng Soyum Centre became an important actor among indigenous agencies. By not only formulating but also carrying out its initiatives, the Centre started the appear almost as determining as the government itself, thus replacing the governmental monopoly with a dynamic theoretical competition in shaping the discourse, representation and life of the Ob-Ugric peoples in Khanty-Mansiysk. After her inauguration, the new governor of the Khanty-Mansi Autonomous Okrug payed her first official visit to the Lylyng Soyum Centre and a spent significant fraction of her speeches emphasising the importance of Ob-Ugric peoples for the Okrug and its government.

11.4. The effects of the Mansi language revitalisation movements on the language vitality of the Mansi language in Khanty-Mansiysk

As a result of the activities of the Lylyng Soyum Centre, Mansi language use, and thus the situation Mansi language vitality of Khanty-Mansiysk has been changed. The most 
significant change in the domain of family language use is the ambition of Mansi-speaking parents sending their children to attend the programs of the Centre, to increase the use of the Mansi language in family conversations, while parents without proficiency in Mansi often wish to acquire the Mansi language. Also, in 2015, for the first time since fieldwork has been carried out in the Khanty-Mansi Autonomous Okrug, a group of parents expressed their wish to teach and educate their children to become fluent speakers of the Mansi language.

The educational system of the Mansi language in Khanty-Mansiysk was radically transformed in several respects. As a result of the activity of the teachers working for the Lylyng Soyum Centre, Mansi language courses are held not only at the Lylyng Soyum Centre, but the teachers also teach classes in other preschools and primary schools of Khanty-Mansiysk which are part of the state education network. As a result of non-governmental and independent initiatives, some urban schools have started to offer Mansi language courses since 2014. As a result of the increased interest in Khanty-Mansiysk, the Khanty-Mansiysk Office for Educational Development has designed and published a family of experimental textbooks that teach the Mansi language not as a mother tongue but as a second/foreign language.

In addition to the transformation of the state supported and alternative education systems, self-organised language acquisition initiatives have also appeared in the city. Besides teach yourself groups founded by students and other motivated youngsters, haphazardly run handicraft groups with Mansi as the language of conversation appeared in town. (The emphasis is on the appearance of such initiatives and the underlying attitudes, since none of these initiatives operated for a longer time.) The teachers and students of the Lylyng Soyum Centre regularly appear on air in the episodes of Yugorika, a language teaching video series broadcast at the local TV channel Yugra. The Office for Education Development, the Mansi newspaper Luima Seripos, and the Lylyng Soyum Centre coordinate the organisation of annual competitions for the teachers of indigenous languages, as well as competitions for students, focusing on Mansi grammar and Mansi literature In Khanty-Mansiysk (and the Khanty-Mansi Autonomous District)

In summary, as a result of educational activities of the Lylyng Soyum Centre, the Mansi language revitalisation initiatives appearing in Khanty-Mansiysk in the 2000s are already able to deliver results, despite of the relatively short time that has elapsed. The revitalisation initiatives stabilised the presence of the Mansi language at the already existing domains of language use and increased the activity of language use at the urban domains, by raising the 
number of participating speakers on the one hand, and the number of institutions and events providing opportunities for language use on the other hand. As a result of revitalisation initiatives, a group of active Mansi adults appeared in Khanty-Mansiysk who advocate and support Mansi language use in the family. As a result of the revitalisation initiatives, state supported education also recognised one of the main problems of Mansi language teaching and, accordingly, began to transform the system of state education by offering more opportunities to study indigenous minority languages in cities and publishing textbooks applying the principles of heritage language teaching.

\title{
11.5. The future of the Mansi language
}

The opinion about the future of the Mansi language depends very much on the consultant's present situation and history of private language use. Comparing these opinions, it is prominent, how the age and personal commitment of transmitting the language to the next generation seem to correlate with consultants' opinion, at the same time, the younger the consultants are the more positively they seem to think about language maintenance or revival. For example Consultant 63, a locally well renown specialist, who has been working with Mansi folklore texts for a very long time, but in her private life has not transmitted her knowledge on the Mansi language, had a very strict judgement on contemporary language use and a very pessimistic forecast on the vitality of Mansi:

\begin{abstract}
It seems to me that your Hungarian school is ideal in the sense that it stands still. [...] You are lucky in the sense that Munkácsi wrote everything down and you go according to this school. [...] You have to have competently designed instruction of language learning [...] on a very high scientific level. But in Russia, since native languages were forbidden to us, it's like optional. And when it will be necessary to revive the language, there is no base. [...] We know little of the living language. [...] The contemporary Mansi language is, let's say, the child of our language. You have the base, on this base any child can be born, if the genes are good. But we have no genes left and there is no one to give birth for.
\end{abstract}

Consultant 3, also highly qualified specialist, somewhat 20 years younger than Consultant 63 is also pessimistic about the expectancies concerning Mansi, stating that "it is sad to think about, that it is improbable for Mansi to be heard in 2050. Many languages will disappear, and Mansi is among them". Still, she admits that there are children who are interested in Mansi and wish 
to learn it, and although she did not raised her own children speaking Mansi, she is willing to help with her language expertise everyone who aim to maintain or revive the language.

Consultant 15, approximately Consultant 3's peer had a very similar practice in using the language (and not transmitting it to her children), a similarly negative opinion about the future, but at the same time a very critical judgement of her generation and a supporting approach to language attitudes.

Only the written language will remain, the spoken language won't survive, because there is no one to talk to. I have many nieces and nephews, they are all Mansi, but I still can't talk to them. [...] It is really difficult to think about the disappearance of our language and culture. We are cutting down the tree we are sitting on. [...] While our generation is alive, something may happen, but slowly our children will grow up, who don't speak the language and have never been living in the culture. [...] If a school would open, offering the full teaching plan both in Russian and Mansi, there would be applicants, but they would keep distance from education in Mansi only. [...] I do hope the Mansi language has a future.

Consultant 23 was one of the first young parents, who decided to raise his children speaking Mansi, and to leave Khanty-Mansiysk, moving be to the Mansi-speaking countryside. Instead of merely meditating about the future of the language, Consultant 23 rather focused on the responsibilities and tasks of the present.

I think Mansi will be heard in 50-70 years from now. One, of course, hopes that it would be heard for a longer time, not only 50 years. [...] It depends only on us, on the community. We have to raise children speaking the language and knowing the culture. Thus their neighbours may be awaken as well. Those who knew the language but didn't speak it. They may be awakened. 


\section{Closing remarks}

The advent of the new millennium found the Mansi of the Khanty-Mansi Autonomous Okrug in a slightly different sociolinguistic situation than they have been living since the Second World War. They witnessed the gradual disappearance of their traditional life style as well as the arrival of a technical and economic boost, and the Mansi speakers as a community just as the Mansi individuals separately gave very diverse answers to the challenges of the new era.

By 2000 there were already 1,000 Mansis living in Khanty-Mansiysk city, the capital, the administrative and cultural centre of the Okrug, using the available facilities of cultural life and domains of cultural life. Since these institutions and domains were founded in order to serve all-regional purposes, the urban Mansis of Khanty-Mansiysk remained without an urban domain. One of the actors aiming to create a domain for the urban Mansi was the founding director of the Lylyng Soyum Centre, an alternative educational institution, which later became the engine or revitalisation attempts and the focus of bottom-up initiatives.

As a result of the activity of the Lylyng Soyum Centre, awareness of the indigenous peoples and interest in their cultures and languages have been rising in Khanty-Mansiysk, both among the representatives of the majority society and the Mansi themselves. Although the basic tendencies characterising the situation of Mansi language vitality have not changed radically, the community is still undergoing language shift, and the transgenerational transmission of the language and successful heritage language education in the Mansi language are more of a dream than reality, however, many new features of urban language use have emerged in the last one and a half decades that no one could predict before.

As for the linguistic landscape, the Mansi language has become visible on the streets of Khanty-Mansiysk. Regarding language attitudes, knowing and speaking Mansi has become one of the most fundamental markers of ethnic identity. In respect of the domains of Mansi language use, many formerly completely unknown domains were created in urban settings, to mention only a few, the press, media, theatre or contemporary music. Mansi language education is both required and provided by Mansis, and the regional offices with Mansi specialists try the follow and satisfy the needs by supporting the establishment of the continuous presence of Mansi in 
the local state supported schools and in publishing new Mansi schoolbooks for heritage language learners.

It is difficult to make a presumption about future political decisions, but there are no signs indicating changes in the leadership of Russia or the Khanty-Mansi Autonomous Okrug, thus, presumably. the federal and regional policy regarding indigenous minorities will remain unchanged as well. But besides the big actors there are also small actors with smaller decisions. In 2021 Consultant 15 will reach retirement age, we shall see whether she will continue working in her present position or retire and start a new project in her free time? Consultant 23's older child and Consultant 2's younger child will go to first grade, in the countryside and in the capital respectively, we shall see who will be in a better position to get Mansi education. Consultant 59's first child will slowly start to speak, we shall see in which language(s). In 2021 the postponed Russian federal census will be held, and we shall see whether the trends will continue or whether there will be differences in the number of speakers.

The Lylyng Soyum Centre has been open for almost twenty years, nearly fifteen years of which period it has spent as a focus of sociolinguistic observation. It would be important to continue this observation until the appearance of the first Mansi-Russian bilingual speakers raised or trained in Khanty-Mansiysk, and then researching their language use, comparing it with the variety used in the traditional territories. But experiencing the hardly sensible signs of political and economic climate change, the surest hope to have is to celebrate the $20^{\text {th }}$ anniversary of the Lylyng Soyum Centre before deciding whether this new climate change brings happier conditions. 
О̄выл ла̄тын

Ты диссертация хансум нэ̄пакумт ам Ханты-Мансийск ӯст ма̄ньщи ла̄тың ва̄нэ тэ̄лат урыл хансэ̄гум. Ма̄ньщи ла̄тың - тыи Сибирьт о̄лнэ мощщаг хультум сосса ма̄хум ла̄тнаныл, та̄н финно-угор мирыт палт рӯтыг о̄лэ̄гыт. Ма̄ньщи ла̄тың - Россия яныг ма̄ янытыл потыртан ма̄хум халт сака ма̄нь. Тыхо̄тал янгыщ ёрн колт о̄лнэ са̄лы янмалтан ма̄хум потыртэ̄гыт ос рэ̄п ма̄ньщи э̄ргыл ищхйпың ут хосыт э̄ргаве. Ща̄нь ла̄тың ва̄нэ хо̄тпат ань мо̄т ма̄хум халт уусытт о̄лэ̄гыт, са̄в мирын ма̄т рӯпитэ̄гыт, ты коныпал то̄ват мо̄т мир колта̄гылт яныгме̄гыт. Ань ӯст о̄лнэ ос тот яныгман хо̄тпатн ма̄ньщи ла̄тың та̄рвитыу ханищтанкве ёмтыс, тувыл потырталнэ ма̄ о̄с а̄тим. Нэ̄пакумт туп то̄ва колыт хӯлтсанум: тыи «Лӯима̄ сэ̄рипос» ма̄ньщи газета редакция, ща̄нь ла̄тныл потыртан телерадиокомпаният рӯпитан хо̄тпат, А̄с-угорский ма̄хум театр, А̄c-угорский ма̄хум институт ос «Лылың со̄юм» нйврам ханищтан кол. Ам пуссын ты колытн щалтыгласум, амки самагум рӯпатаныл суссум, ты ма̄хмыт ёт потыртасум ос матыр-а̄ти та̄ра-паттысум. Ам та̄наныл китыгласанум: Ханты-Мансийск ӯст ма̄ньщит маныр ва̄ре̄гыт? Та̄нки ща̄нь ла̄тнаныл урыл маныр э̆лаль номсэ̄гыт? Хо̄т та̄н ма̄ньщи ла̄туыл потыртэ̄гыт? Ща̄нь ла̄тныл потыртаукв та̄нки нйвраманыл ханищтанкве таухэ̄гыт ман а̄ти? Манах институтыт ма̄ньщи ла̄тың но̄х-ва̄рмалтым ос э̄лаль тотнэ ма̄гыс рӯпитэ̄гыт? Ща̄нь ла̄тың эллаль тотнэ щирыл маныр номсэ̄гыт? Ты нэ̄пакт маныр тэ̄лат ам та̄ра-паттысум, таит хансыянум. Ам ётум потыртан ма̄ньщи хо̄тпат ӯсн са̄в ма̄ныл ёхтысыт, та̄н са̄всыр ма̄т рӯпитэ̄гыт, ка̄сың хо̄тпа такви щире̄тыл ма̄ньщи ла̄тың о̄вылтыт номсы. Ос ка̄сың хо̄тпа ща̄нь ла̄тңе э̄руптытэ ос та̄нки о̄лупсаныл ма̄ньщи пе̄с накыт ӯргалым, э̄рнэ̄г о̄ньщияныл.

(ма̄ньщи ла̄туыл Т.С. Мерова толмащластэ)

Резюме

В своей диссертации я пишу о состоянии мансийского языка в Ханты-Мансийске. Мансийский язык - один из языков коренных малочисленных народов Сибири, он принадлежит к языковой семье финно-угорских языков. Мансийский язык - маленький язык в большой стране, язык на котором говорят как оленеводы, так и рэпперы, язык на котором говорят в чумах, а также в интернете. Носители мансийского языка в городах живут в многоязычном и полиэтническом обществе, часто в многонациональных семьях. 
Хотя многие манси живут в городах, выучить там мансийский язык - сложно, а также трудно найти места, где можно говорить на нем. В диссертации представлены некоторые из таких мест: редакция мансийской газеты «Луима Серипос», мансийские теле- и радиопрограммы, Театр обско-угорских народов, Обско-угорский научноисследовательский институт, образовательный центр «Лилинг союм». Я побывала в этих местах, понаблюдала их важную работу, поговорила с манси работающими в этих местах, и спросила их мнение. Я искала ответ на вопросы: чем занимаются манси в Ханты-Мансийске? Как они думают о мансийском языке? Где они говорят на мансийском языке? Хотят ли они научить языку своих детей? Какие институты работают, чтобы поддерживать, возрождать мансийский язык? Как манси думают о будущем мансийского языка? В этой диссертации я записываю то, что узнала. Те люди, которые говорили со мной о мансийском языке, приехали из разных мест, работают поразному, по-разному думают о будущем языка, но все они любят мансийский язык и все считают его важной частью мансийской культуры и их собственной жизни. 
Appendix

Table summarising the respondents' sociolinguistic data

\begin{tabular}{|c|c|c|c|c|c|c|}
\hline CONSULTANT & SEX & ETHNICITY & AGE & $\begin{array}{l}\text { HOME } \\
\text { REGION }\end{array}$ & $\begin{array}{l}\text { PROFICIENCY IN } \\
\text { INDIGENOUS } \\
\text { LANGUAGES }\end{array}$ & PROFESSION \\
\hline 1 & $\mathrm{~F}$ & Mansi & pensioner & $\begin{array}{l}\text { Mansi } \\
\text { settlement in } \\
\text { Berezovskiy } \\
\text { rayon }\end{array}$ & $\begin{array}{l}\text { native speaker of } \\
\text { Mansi }\end{array}$ & $\begin{array}{l}\text { kolkhoz- } \\
\text { worker }\end{array}$ \\
\hline 2 & $F$ & Mansi & $\begin{array}{l}\text { middle- } \\
\text { aged }\end{array}$ & $\begin{array}{l}\text { Mansi } \\
\text { settlement in } \\
\text { Berezovskiy } \\
\text { rayon }\end{array}$ & $\begin{array}{l}\text { native speaker of } \\
\text { Mansi }\end{array}$ & $\begin{array}{l}\text { media } \\
\text { worker }\end{array}$ \\
\hline 3 & $\mathrm{~F}$ & Mansi & $\begin{array}{l}\text { middle- } \\
\text { aged }\end{array}$ & $\begin{array}{l}\text { Mansi } \\
\text { settlement in } \\
\text { Berezovskiy } \\
\text { rayon }\end{array}$ & $\begin{array}{l}\text { native speaker of } \\
\text { Mansi }\end{array}$ & $\begin{array}{l}\text { media } \\
\text { worker }\end{array}$ \\
\hline 4 & $\mathrm{~F}$ & Mansi & $\begin{array}{l}\text { middle- } \\
\text { aged }\end{array}$ & $\begin{array}{l}\text { Mansi } \\
\text { settlement in } \\
\text { Berezovskiy } \\
\text { rayon }\end{array}$ & $\begin{array}{l}\text { native speaker of } \\
\text { Mansi }\end{array}$ & $\begin{array}{l}\text { administrativ } \\
\text { e worker }\end{array}$ \\
\hline 8 & $\mathrm{~F}$ & Mansi & young adult & $\begin{array}{l}\text { Khanty- } \\
\text { Mansiysk }\end{array}$ & $\begin{array}{l}\text { speaks Russian } \\
\text { only }\end{array}$ & student \\
\hline 9 & $\mathrm{~F}$ & Mansi & child & $\begin{array}{l}\text { Khanty- } \\
\text { Maniysk }\end{array}$ & $\begin{array}{ll}\text { speaks Russian } \\
\text { only }\end{array}$ & student \\
\hline 10 & $\mathrm{M}$ & Mansi & young adult & $\begin{array}{l}\text { Khanty- } \\
\text { Maniysk }\end{array}$ & $\begin{array}{ll}\text { speaks Russian } \\
\text { only }\end{array}$ & student \\
\hline 11 & $\mathrm{~F}$ & Mansi & child & $\begin{array}{l}\text { Khanty- } \\
\text { Maniysk }\end{array}$ & $\begin{array}{l}\text { speaks Russian } \\
\text { only }\end{array}$ & student \\
\hline 12 & $\mathrm{M}$ & Mansi & young adult & $\begin{array}{l}\text { Mansi } \\
\text { settlement in } \\
\text { Berezovskiy } \\
\text { rayon }\end{array}$ & $\begin{array}{l}\text { native speaker of } \\
\text { Mansi }\end{array}$ & teacher \\
\hline 13 & $\mathrm{~F}$ & Mansi & pensioner & $\begin{array}{l}\text { Mansi } \\
\text { settlement in } \\
\text { Berezovskiy } \\
\text { rayon }\end{array}$ & $\begin{array}{l}\text { native speaker of } \\
\text { Mansi }\end{array}$ & $\begin{array}{l}\text { kolkhoz- } \\
\text { worker }\end{array}$ \\
\hline 14 & $\mathrm{M}$ & Mansi & young adult & $\begin{array}{l}\text { Mansi } \\
\text { settlement in }\end{array}$ & $\begin{array}{l}\text { native speaker of } \\
\text { Mansi }\end{array}$ & $\begin{array}{l}\text { media- } \\
\text { worker }\end{array}$ \\
\hline
\end{tabular}




\begin{tabular}{|c|c|c|c|c|c|c|}
\hline & & & & $\begin{array}{l}\text { Berezovskiy } \\
\text { rayon }\end{array}$ & & \\
\hline 15 & $\mathrm{~F}$ & Mansi & $\begin{array}{l}\text { middle- } \\
\text { aged }\end{array}$ & $\begin{array}{l}\text { Mansi } \\
\text { settlement in } \\
\text { Berezovskiy } \\
\text { rayon }\end{array}$ & $\begin{array}{l}\text { native speaker of } \\
\text { Mansi }\end{array}$ & $\begin{array}{l}\text { media- } \\
\text { worker }\end{array}$ \\
\hline 17 & $\mathrm{~F}$ & Mansi & young adult & $\begin{array}{l}\text { Mansi } \\
\text { settlement in } \\
\text { Berezovskiy } \\
\text { rayon }\end{array}$ & $\begin{array}{l}\text { native speaker of } \\
\text { Mansi }\end{array}$ & $\begin{array}{l}\text { media- } \\
\text { worker }\end{array}$ \\
\hline 21 & $\mathrm{~F}$ & Mansi & young adult & $\begin{array}{l}\text { Mansi } \\
\text { settlement in } \\
\text { Berezovskiy } \\
\text { rayon }\end{array}$ & $\begin{array}{l}\text { native speaker of } \\
\text { Mansi }\end{array}$ & $\begin{array}{l}\text { media- } \\
\text { worker }\end{array}$ \\
\hline 22 & $\mathrm{~F}$ & Mansi & young adult & $\begin{array}{l}\text { Mansi } \\
\text { settlement in } \\
\text { Berezovskiy } \\
\text { rayon }\end{array}$ & $\begin{array}{l}\text { native speaker of } \\
\text { Mansi }\end{array}$ & $\begin{array}{l}\text { media- } \\
\text { worker }\end{array}$ \\
\hline 23 & $\mathrm{M}$ & Mansi & young adult & $\begin{array}{l}\text { Mansi } \\
\text { settlement in } \\
\text { Berezovskiy } \\
\text { rayon }\end{array}$ & $\begin{array}{l}\text { native speaker of } \\
\text { Mansi }\end{array}$ & $\begin{array}{l}\text { media- } \\
\text { worker }\end{array}$ \\
\hline 24 & $\mathrm{~F}$ & Mansi & young adult & $\begin{array}{l}\text { Mansi } \\
\text { settlement in } \\
\text { Berezovskiy } \\
\text { rayon }\end{array}$ & $\begin{array}{l}\text { attanded Mansi } \\
\text { classes at school }\end{array}$ & teacher \\
\hline 25 & $\mathrm{~F}$ & Mansi & child & $\begin{array}{l}\text { Mansi } \\
\text { settlement in } \\
\text { Berezovskiy } \\
\text { rayon }\end{array}$ & $\begin{array}{l}\text { native speaker of } \\
\text { Mansi }\end{array}$ & student \\
\hline 27 & $\mathrm{~F}$ & Mansi & pensioner & $\begin{array}{l}\text { Mansi } \\
\text { settlement in } \\
\text { Berezovskiy } \\
\text { rayon }\end{array}$ & $\begin{array}{l}\text { native speaker of } \\
\text { Mansi }\end{array}$ & $\begin{array}{l}\text { scientific } \\
\text { worker }\end{array}$ \\
\hline 28 & $\mathrm{~F}$ & Mansi & young adult & $\begin{array}{l}\text { Khanty- } \\
\text { Mansiysk }\end{array}$ & $\begin{array}{l}\text { attended Mansi } \\
\text { classes at school }\end{array}$ & teacher \\
\hline 29 & $\mathrm{M}$ & Mansi & child & $\begin{array}{l}\text { Khanty- } \\
\text { Mansiyk }\end{array}$ & $\begin{array}{l}\text { speaks Russian } \\
\text { only }\end{array}$ & student \\
\hline 30 & $\mathrm{~F}$ & Mansi & young adult & $\begin{array}{l}\text { Mansi } \\
\text { settlement in } \\
\text { Berezovskiy } \\
\text { rayon }\end{array}$ & $\begin{array}{l}\text { native speaker of } \\
\text { Mansi }\end{array}$ & teacher \\
\hline 35 & $\mathrm{~F}$ & Mansi & young adult & $\begin{array}{l}\text { Mansi } \\
\text { settlement in }\end{array}$ & $\begin{array}{l}\text { native speaker of } \\
\text { Mansi }\end{array}$ & teacher \\
\hline
\end{tabular}




\begin{tabular}{|c|c|c|c|c|c|c|}
\hline & & & & $\begin{array}{l}\text { Berezovskiy } \\
\text { rayon }\end{array}$ & & \\
\hline 36 & $\mathrm{M}$ & Tajik & $\begin{array}{l}\text { middle- } \\
\text { aged }\end{array}$ & Tajikistan & $\begin{array}{l}\text { speaks Russian } \\
\text { only }\end{array}$ & $\begin{array}{l}\text { physical } \\
\text { worker }\end{array}$ \\
\hline 37 & $\mathrm{M}$ & Mansi & young adult & $\begin{array}{l}\text { Khanty- } \\
\text { Mansiysk }\end{array}$ & $\begin{array}{l}\text { speaks Russian } \\
\text { only }\end{array}$ & $\begin{array}{l}\text { physical } \\
\text { worker }\end{array}$ \\
\hline 40 & $\mathrm{~F}$ & Mansi & young adult & $\begin{array}{l}\text { Khanty- } \\
\text { Mansiysk }\end{array}$ & $\begin{array}{l}\text { attended Mansi } \\
\text { classes at school }\end{array}$ & student \\
\hline 41 & $\mathrm{~F}$ & Mansi & child & $\begin{array}{l}\text { Khanty- } \\
\text { Manisyk }\end{array}$ & $\begin{array}{l}\text { attended Mansi } \\
\text { classes at school }\end{array}$ & student \\
\hline 42 & $\mathrm{M}$ & Mansi & $\begin{array}{l}\text { middle- } \\
\text { aged }\end{array}$ & $\begin{array}{l}\text { Mansi } \\
\text { settlement in } \\
\text { Berezovskiy } \\
\text { rayon }\end{array}$ & $\begin{array}{l}\text { native speaker of } \\
\text { Mansi }\end{array}$ & $\begin{array}{l}\text { scientific } \\
\text { worker }\end{array}$ \\
\hline 43 & $\mathrm{~F}$ & Tatar & $\begin{array}{l}\text { middle- } \\
\text { aged }\end{array}$ & $\begin{array}{l}\text { Bashkortosta } \\
\mathrm{n}\end{array}$ & $\begin{array}{l}\text { speaks Russian } \\
\text { only }\end{array}$ & $\begin{array}{l}\text { physical } \\
\text { worker }\end{array}$ \\
\hline 48 & $\mathrm{M}$ & Mansi & young adult & $\begin{array}{l}\text { Bashkortosta } \\
\mathrm{n}\end{array}$ & $\begin{array}{l}\text { attended Mansi } \\
\text { classes at school }\end{array}$ & $\begin{array}{l}\text { scientific } \\
\text { worker }\end{array}$ \\
\hline 50 & $\mathrm{M}$ & Mansi & child & $\begin{array}{l}\text { Khanty- } \\
\text { Mansiysk }\end{array}$ & $\begin{array}{l}\text { speaks Russian } \\
\text { only }\end{array}$ & student \\
\hline 51 & $\mathrm{~F}$ & Mansi & child & $\begin{array}{l}\text { Khanty- } \\
\text { Mansiysk }\end{array}$ & $\begin{array}{l}\text { speaks Russian } \\
\text { only }\end{array}$ & student \\
\hline 52 & $\mathrm{~F}$ & Mansi & young adult & $\begin{array}{l}\text { Mansi } \\
\text { settlement in } \\
\text { Berezovskiy } \\
\text { rayon }\end{array}$ & $\begin{array}{l}\text { native speaker of } \\
\text { Mansi }\end{array}$ & $\begin{array}{l}\text { scientific } \\
\text { worker }\end{array}$ \\
\hline 53 & $\mathrm{~F}$ & Mansi & pensioner & $\begin{array}{l}\text { Mansi } \\
\text { settlement in } \\
\text { Berezovskiy } \\
\text { rayon }\end{array}$ & $\begin{array}{l}\text { attended Mansi } \\
\text { classes at school }\end{array}$ & $\begin{array}{l}\text { scientific } \\
\text { worker }\end{array}$ \\
\hline 54 & $\mathrm{M}$ & Mansi & young adult & $\begin{array}{l}\text { Mansi } \\
\text { settlement in } \\
\text { Berezovskiy } \\
\text { rayon }\end{array}$ & $\begin{array}{l}\text { speaks Russian } \\
\text { only }\end{array}$ & artist \\
\hline 58 & $\mathrm{M}$ & Mansi & young adult & $\begin{array}{l}\text { Mansi } \\
\text { settlement in } \\
\text { Berezovskiy } \\
\text { rayon }\end{array}$ & $\begin{array}{l}\text { speaks Russian } \\
\text { only }\end{array}$ & artist \\
\hline 59 & $\mathrm{M}$ & Mansi & young adult & $\begin{array}{l}\text { Mansi } \\
\text { settlement in } \\
\text { Berezovskiy } \\
\text { rayon }\end{array}$ & $\begin{array}{l}\text { native speaker of } \\
\text { Mansi }\end{array}$ & artist \\
\hline
\end{tabular}




\begin{tabular}{|c|c|c|c|c|c|c|}
\hline 60 & $\mathrm{M}$ & Mansi & young adult & $\begin{array}{l}\text { Mansi } \\
\text { settlement in } \\
\text { Berezovskiy } \\
\text { rayon }\end{array}$ & $\begin{array}{l}\text { native speaker of } \\
\text { Mansi }\end{array}$ & artist \\
\hline 61 & $\mathrm{M}$ & Mansi & young adult & $\begin{array}{l}\text { Mansi } \\
\text { settlement in } \\
\text { Berezovskiy } \\
\text { rayon }\end{array}$ & $\begin{array}{l}\text { native speaker of } \\
\text { Mansi }\end{array}$ & artist \\
\hline 62 & $\mathrm{~F}$ & Mansi & pensioner & $\begin{array}{l}\text { Mansi } \\
\text { settlement in } \\
\text { Berezovskiy } \\
\text { rayon }\end{array}$ & $\begin{array}{l}\text { native speaker of } \\
\text { Mansi }\end{array}$ & $\begin{array}{l}\text { scientific } \\
\text { worker }\end{array}$ \\
\hline 63 & $\mathrm{~F}$ & Mansi & \begin{tabular}{|l|} 
pensioner \\
\end{tabular} & $\begin{array}{l}\text { Mansi } \\
\text { settlement in } \\
\text { Berezovskiy } \\
\text { rayon }\end{array}$ & $\begin{array}{l}\text { native speaker of } \\
\text { Mansi }\end{array}$ & $\begin{array}{l}\text { scientific } \\
\text { worker }\end{array}$ \\
\hline 64 & $\mathrm{~F}$ & Mansi & young adult & $\begin{array}{l}\text { Mansi } \\
\text { settlement in } \\
\text { Berezovskiy } \\
\text { rayon }\end{array}$ & $\begin{array}{l}\text { native speaker of } \\
\text { Mansi }\end{array}$ & $\begin{array}{l}\text { administrativ } \\
\text { e worker }\end{array}$ \\
\hline 65 & $\mathrm{~F}$ & Mansi & $\begin{array}{l}\text { middle- } \\
\text { aged }\end{array}$ & $\begin{array}{l}\text { Mansi } \\
\text { settlement in } \\
\text { Berezovskiy } \\
\text { rayon }\end{array}$ & $\begin{array}{l}\text { native speaker of } \\
\text { Mansi }\end{array}$ & $\begin{array}{l}\text { scientific } \\
\text { worker }\end{array}$ \\
\hline 66 & $\mathrm{~F}$ & Mansi & young adult & $\begin{array}{l}\text { Khanty- } \\
\text { Mansiysk }\end{array}$ & $\begin{array}{l}\text { speaks Russian } \\
\text { only }\end{array}$ & $\begin{array}{l}\text { administrativ } \\
\text { e worker }\end{array}$ \\
\hline 68 & $\mathrm{M}$ & $?$ & child & $\begin{array}{l}\text { Khanty- } \\
\text { Mansiysk }\end{array}$ & $\begin{array}{l}\text { speaks Russian } \\
\text { only }\end{array}$ & student \\
\hline 69 & $\mathrm{~F}$ & Mansi & $\begin{array}{l}\text { middle- } \\
\text { aged }\end{array}$ & $\begin{array}{l}\text { Mansi } \\
\text { settlement in } \\
\text { Berezovskiy } \\
\text { rayon }\end{array}$ & $\begin{array}{l}\text { native speaker of } \\
\text { Mansi }\end{array}$ & $\begin{array}{l}\text { administrativ } \\
\text { e worker }\end{array}$ \\
\hline 71 & $\mathrm{~F}$ & Mansi & young adult & $\begin{array}{l}\text { Mansi } \\
\text { settlement in } \\
\text { Berezovskiy } \\
\text { rayon }\end{array}$ & $\begin{array}{l}\text { attended Mansi } \\
\text { classes at school }\end{array}$ & $\begin{array}{l}\text { administrativ } \\
\text { e worker }\end{array}$ \\
\hline 75 & $\mathrm{M}$ & Mansi & young adult & $\begin{array}{l}\text { Mansi } \\
\text { settlement in } \\
\text { Berezovskiy } \\
\text { rayon }\end{array}$ & $\begin{array}{l}\text { attended Mansi } \\
\text { classes at school }\end{array}$ & artist \\
\hline 79 & $\mathrm{M}$ & Mansi & young adult & $\begin{array}{l}\text { Mansi } \\
\text { settlement in } \\
\text { Ivdelskiy } \\
\text { rayon }\end{array}$ & $\begin{array}{l}\text { native speaker of } \\
\text { Mansi }\end{array}$ & $\begin{array}{l}\text { administrativ } \\
\text { e worker }\end{array}$ \\
\hline
\end{tabular}




\begin{tabular}{|c|c|c|c|c|c|c|}
\hline 83 & $\mathrm{~F}$ & Mansi & $\begin{array}{l}\text { middle- } \\
\text { aged }\end{array}$ & $\begin{array}{l}\text { Mansi } \\
\text { settlement in } \\
\text { Oktyabrskiy } \\
\text { rayon }\end{array}$ & $\begin{array}{l}\text { native speaker of } \\
\text { Mansi }\end{array}$ & $\begin{array}{l}\text { scientific } \\
\text { worker }\end{array}$ \\
\hline 85 & $\mathrm{M}$ & Mansi & $\begin{array}{l}\text { middle- } \\
\text { aged }\end{array}$ & $\begin{array}{l}\text { Mansi } \\
\text { settlement in } \\
\text { Oktyabrskiy } \\
\text { rayon }\end{array}$ & $\begin{array}{l}\text { native speaker of } \\
\text { Mansi }\end{array}$ & $\begin{array}{l}\text { physical } \\
\text { worker }\end{array}$ \\
\hline 87 & $\mathrm{M}$ & Mansi & child & $\begin{array}{l}\text { Khanty- } \\
\text { Mansiysk }\end{array}$ & $\begin{array}{l}\text { attended Mansi } \\
\text { classes at school }\end{array}$ & student \\
\hline 88 & $\mathrm{M}$ & Mansi & young adult & $\begin{array}{l}\text { Mansi } \\
\text { settlement in } \\
\text { Kondinskiy } \\
\text { rayon }\end{array}$ & $\begin{array}{l}\text { attended Mansi } \\
\text { classes at school }\end{array}$ & $\begin{array}{l}\text { scientific } \\
\text { worker }\end{array}$ \\
\hline 91 & $\mathrm{M}$ & Mansi & young adult & $\begin{array}{l}\text { Mansi } \\
\text { settlement in } \\
\text { Kondinskiy } \\
\text { rayon }\end{array}$ & $\begin{array}{l}\text { speaks Russian } \\
\text { only }\end{array}$ & $\begin{array}{l}\text { scientific } \\
\text { worker }\end{array}$ \\
\hline 95 & $\mathrm{~F}$ & Mansi & young adult & $\begin{array}{l}\text { Khanty- } \\
\text { Mansiysk }\end{array}$ & $\begin{array}{l}\text { speaks Russian } \\
\text { only }\end{array}$ & $\begin{array}{l}\text { media } \\
\text { worker }\end{array}$ \\
\hline 96 & $\mathrm{M}$ & Mansi & child & $\begin{array}{l}\text { Khanty- } \\
\text { Mansiysk }\end{array}$ & $\begin{array}{l}\text { speaks Russian } \\
\text { only }\end{array}$ & student \\
\hline 97 & $\mathrm{M}$ & Mansi & $\begin{array}{l}\text { middle- } \\
\text { aged }\end{array}$ & $\begin{array}{l}\text { Mansi } \\
\text { settlement in } \\
\text { Berezovskiy } \\
\text { rayon }\end{array}$ & $\begin{array}{l}\text { native speaker of } \\
\text { Mansi }\end{array}$ & $\begin{array}{l}\text { physical } \\
\text { worker }\end{array}$ \\
\hline 98 & $\mathrm{~F}$ & Mansi & $\begin{array}{l}\text { middle- } \\
\text { aged }\end{array}$ & $\begin{array}{l}\text { Khanty- } \\
\text { Mansiysk }\end{array}$ & $\begin{array}{l}\text { speaks Russian } \\
\text { only }\end{array}$ & $\begin{array}{l}\text { scientific } \\
\text { worker }\end{array}$ \\
\hline 99 & $\mathrm{~F}$ & Mansi & young adult & $\begin{array}{l}\text { Khanty- } \\
\text { Mansiysk }\end{array}$ & $\begin{array}{l}\text { speaks Russian } \\
\text { only }\end{array}$ & student \\
\hline 100 & $F$ & Mansi & child & $\begin{array}{l}\text { Khanty- } \\
\text { Mansiysk }\end{array}$ & $\begin{array}{l}\text { speaks Russian } \\
\text { only }\end{array}$ & student \\
\hline 101 & $\mathrm{~F}$ & Mansi & pensioner & $\begin{array}{l}\text { Mansi } \\
\text { settlement in } \\
\text { Berezovskiy } \\
\text { rayon }\end{array}$ & $\begin{array}{l}\text { native speaker of } \\
\text { Mansi }\end{array}$ & $\begin{array}{l}\text { scientific } \\
\text { worker }\end{array}$ \\
\hline 102 & $\mathrm{~F}$ & $?$ & $\begin{array}{l}\text { middle- } \\
\text { aged }\end{array}$ & $\begin{array}{l}\text { Khanty- } \\
\text { Mansiysk }\end{array}$ & $\begin{array}{l}\text { speaks Russian } \\
\text { only }\end{array}$ & $\begin{array}{l}\text { scientific } \\
\text { worker }\end{array}$ \\
\hline 103 & $\mathrm{M}$ & Mansi & young adult & $\begin{array}{l}\text { Mansi } \\
\text { settlement in } \\
\text { Berezovskiy } \\
\text { rayon }\end{array}$ & $\begin{array}{l}\text { native speaker of } \\
\text { Mansi }\end{array}$ & $\begin{array}{l}\text { medical } \\
\text { worker }\end{array}$ \\
\hline
\end{tabular}




\begin{tabular}{|c|c|c|c|c|c|c|}
\hline 104 & $\mathrm{M}$ & Mansi & pensioner & $\begin{array}{l}\text { Mansi } \\
\text { settlement in } \\
\text { Berezovskiy } \\
\text { rayon }\end{array}$ & $\begin{array}{l}\text { native speaker of } \\
\text { Mansi }\end{array}$ & $\begin{array}{l}\text { scientific } \\
\text { worker }\end{array}$ \\
\hline 105 & $\mathrm{M}$ & Mansi & $\begin{array}{l}\text { middle- } \\
\text { aged }\end{array}$ & Leningrad & $\begin{array}{l}\text { speaks Russian } \\
\text { only }\end{array}$ & artist \\
\hline 107 & $F$ & Mansi & pensioner & $\begin{array}{l}\text { Mansi } \\
\text { settlement in } \\
\text { Berezovskiy } \\
\text { rayon }\end{array}$ & $\begin{array}{l}\text { native speaker of } \\
\text { Mansi }\end{array}$ & $\begin{array}{l}\text { scientific } \\
\text { worker }\end{array}$ \\
\hline 108 & $\mathrm{~F}$ & Mansi & $\begin{array}{l}\text { middle- } \\
\text { aged }\end{array}$ & $\begin{array}{l}\text { Mansi } \\
\text { settlement in } \\
\text { Berezovskiy } \\
\text { rayon }\end{array}$ & $\begin{array}{l}\text { native speaker of } \\
\text { Mansi }\end{array}$ & $\begin{array}{l}\text { scientific } \\
\text { worker }\end{array}$ \\
\hline 109 & $\mathrm{M}$ & Turkish & $\begin{array}{l}\text { middle- } \\
\text { aged }\end{array}$ & Turkey & $\begin{array}{l}\text { speaks Russian } \\
\text { only }\end{array}$ & $\begin{array}{l}\text { physical } \\
\text { worker }\end{array}$ \\
\hline 110 & $\mathrm{~F}$ & Mansi & young adult & $\begin{array}{l}\text { Khanty- } \\
\text { Mansiysk }\end{array}$ & $\begin{array}{l}\text { speaks Russian } \\
\text { only }\end{array}$ & student \\
\hline 111 & $\mathrm{~F}$ & Mansi & child & $\begin{array}{l}\text { Khanty- } \\
\text { Mansiysk }\end{array}$ & $\begin{array}{l}\text { speaks Russian } \\
\text { only }\end{array}$ & student \\
\hline 112 & $\mathrm{M}$ & Mansi & young adult & $\begin{array}{l}\text { Mansi } \\
\text { settlement in } \\
\text { Berezovskiy } \\
\text { rayon }\end{array}$ & $\begin{array}{l}\text { attended Mansi } \\
\text { classes at school }\end{array}$ & $?$ \\
\hline
\end{tabular}


Bibliography

Ács, Judit, Pajkossy, Katalin, and Kornai, András. 2017. Digital vitality of Uralic languages. Acta Linguistica Academica, 64 (3): 327-345.

Act N 73-03. Available: https://www.dumahmao.ru/decisions/detail.php?ID=7086 Accessed: 2 February, 2020.

Act N 89-03. Available: http://docs.cntd.ru/document/991009915 Accessed: 2 February, 2020.

Austin, Peter K. and Sallabank, Julia. 2011. Introduction. In: Austin, Peter K. and Sallabank, Julia, eds. The Cambridge handbook of endangered languages. Cambridge: Cambridge University Press, 1-24.

B. Székely, Gábor. 2013. Manysi hangarchívum [Mansi audio archive]. In: Fancsaly, Éva and B. Székely, Gábor, eds. Obi-ugor és szamojéd kutatások, magyar östörténet [Ob Ugric and Samoyed research and the prehistory of Hungarians]. Pécs: Pécsi Tudományegyetem, 223-227.

Babbie, Earl. 2010. The practice of social research. Belmont: Wadsworth

Backhaus, Peter. 2007. Linguistic landscapes. A comparative study of urban multilingualism in Tokyo. Clevedon - Buffalo - Toronto: Multilingual Matters.

Bartels, Dennis. A. and Bartels, Alice. L. 1995. When the North was red: Aboriginal education in Soviet Siberia. Montreal and Kingston: McGill-Queen's University Press.

Bíró, Bernadett and Sipőcz, Katalin. 2009. Language shift among the Mansi. In: Stanford, J. N. and Preston, Dennis R., eds. Variation in indigenous minority languages. Amsterdam: Benjamins, 321-346.

Bíró, Bernadett and Sipőcz, Katalin. 2017. Manysi nyelvről - manysi nyelven [On Mansi - in Mansi]. In: Benő, Attila and Fazekas, Noémi, eds. Élőnyelvi kutatások és a dialektológia. Válogatás a 19. Élőnyelvi Konferencia előadásaiból [Sociolinguistic research and dialectology: Selected papers from the 19th Hungarian Sociolinguistics Conference]. Kolozsvár: Erdélyi Múzeum Egyesület, 283-293.

Bloomsfield, Leonard. 1927. Literate and illiterate speech. American Speech 2, 432-439.

Brennan, Sarah and O'Rourke, Bernadett 2018 Commercialising the cupla focal. New speakers, language, ownership, and promotion of Irish as a business resource. In: Language in Society, 48(1), 125 - 145 
Buchstaller, Isabelle and Khattab, Ghada. 2014. Population samples. In: Podesva, Robert J. and Sharma, Devyani. Research methods in linguistics. Cambridge: Cambridge University Press, 74-95.

Ceberio, Klara, Gurrutxaga, Antton, Soria, Claudia, Russo, Irene, Quochi, Valeria. 2018. How to Use the Digital Language Vitality Scale. Available: http://www.dldp.eu/sites/default/files/documents/DLDP Digital-Language-Vitality-

Scale.pdf Accessed: 17 November, 2020

Census HMAО 20104 Население по национальности и владению русским языком. Online. Date of access: 15 November, $2015^{47}$

Census HМАО 20105 Владение языками насилением. Online. Date of access: 15 November, 2015.

Census HМАО 20106 Владение языками насилением наиболее многочисленных национальностей. Online. Date of access: 15 November, 2015.

Census HМАО 20107 Владение языками населением наиболее многочисленных национальностей в Ханты-Мансийском Автономном Округе - Югре. Online. Date of access: 15 November, 2015.

Census HMAО 20108 Население наиболее многочисленных национальностей по родному языку. Online. Date of access: 15 November, 2015.

Census HMAO 20109 Население наиболее многочисленных национальностей по родному языку в Ханты-Мансийском Автономном Округе - Югре. Online. Date of access: 15 November, 2015.

Census RF 20023 Население по национальности и владению русским языком по субъектам Российской Федерации Available: http://www.perepis2002.ru/ct/doc/TOM 04 03.xls, Accessed: 29 December, 2019. $\begin{array}{llllll}\text { Census } & \text { RF } & 2010 & 4 / 1 & \text { Национальный состав населения }\end{array}$ https://www.gks.ru/free_doc/new_site/perepis2010/croc/Documents/Vol4/pub-0401.xlsx Accessed: 29 December, 2019.

Census RF 2010 4/3 Население по национальности и владению русским языком https://www.gks.ru/free_doc/new_site/perepis2010/croc/Documents/Vol4/pub-0403.xlsx Accessed: 29 December, 2019.

\footnotetext{
${ }^{47}$ The data from the 2010 censuses limited to the Khanty-Mansi Autonomous District I downloaded from the home page of Regional Statistical Office, thus I have a copy of the tables. Unfortunately, since 2015 these statistics have been made inaccessible.
} 
Census RF 2010 4/5 Владение языками населением Российской Федерации, https://www.gks.ru/free doc/new site/perepis2010/croc/Documents/Vol4/pub-0405.xlsx, Accessed: 29 December, 2019.

Census RF 2010 4/8, Население наиболее многочисленных национальностей по родному языку, https:/www.gks.ru/free_doc/new_site/perepis2010/croc/Documents/Vol4/pub04-08.xlsx Accessed: 29 December, 2019.

Census 2010 4/19 Размещение населения коренных малочисленных народов Российской Федерации, https://www.gks.ru/free doc/new_site/perepis2010/croc/Documents/Vol4/pub-0419.xlsx, Accessed: 29 December, 2019.

Census RF 2010 4/20, Владение языками населением коренных малочисленных народов Российской Федерации,

https://www.gks.ru/free_doc/new_site/perepis2010/croc/Documents/Vol4/pub-04-20.xlsx

Accessed: 29 December, 2019.

Census RF 2010 4/22, Население коренных малочисленных народов Российской Федерации по родному языку,

https://www.gks.ru/free_doc/new_site/perepis2010/croc/Documents/Vol4/pub-04-22.xlsx Accessed: 29 December, 2019.

Census RF 2010 4/23 Население коренных малочисленных народов Российской Федерации по родному языку по отдельным субъектам Российской Федерации, https://www.gks.ru/free_doc/new_site/perepis2010/croc/Documents/Vol4/pub-0423.pdf, Accessed: 29 December, 2019.

Census RF 20107 Национальный состав населению по субъектам Российской Федерации, Available: https://www.gks.ru/free_doc/new_site/population/demo/per-itog/tab7.xls, Accessed: 29 December, 2019.

Census SU 1926 Всесоюзная перепись населения 1926 года. Национальный состав населения по республикам CCCP Available: http://www.demoscope.ru/weekly/ssp/ussr_nac_26.php Accessed: 29 December, 2019.

Census SU 1939 Всесоюзная перепись населения 1939 года. Национальный состав населения по республикам Available: http://www.demoscope.ru/weekly/ssp/sng_nac_39.php Accessed: 29 December, 2019.

Coulmas, Florian. 1998. Introduction. In: Coulmas, Florian, ed. The handbook of sociolinguistics. Oxford: Blackwell, 1-11.

Crystal, David. 2011. Internet linguistics: A student guide. London: Taylor \& Francis Group. 
Cummins, Jim. 2005.A proposal for action, strategies for recognizing heritage language competence as a learning resouce within the mainstream classroom. The Modern Language Journal, 89, 585-592.

Cummins, Jim. 2009. Fundamental psycholinguistic and sociological principles underlying educational success for linguistic minority students. In: Skutnabb-Kangas, Tove, Philipson, Robert, Mohanty, Ajit K. and Panda, Minati, eds. Social justice through multilingual education. Clevedon: Multilingual Matters, 19-35.

Csepregi, Márta. 2018. Cseppben a tenger: Esettanulmány a szurguti hanti nyelvi helyzetről [The bucket in a drop: A case study on the linguistic situation of the Surgut Khanty]. In: Csepregi, Márta and Salánki, Zsuzsa, ed. A többnyelvüség dinamikája: A többnyelvüség megnyilvánulásai finnugor nyelvü közösségekben [The dinamics of multilingualism: multilingual practices in Finno-Ugric communities]. Budapest: ELTE BTK Finnugor Tanszék, Numi-Tórem Finnugor Alapítvány, 13-30.

Cseresnyési, László. 2004. Nyelvek és stratégiák, avagy a nyelv antropológiája [Languages and strategies, or the anthropology of language]. Budapest: Tinta.

Dołowy-Rybińska, Nicole. 2020. No one will do this for us: The linguistic and cultural practices of young activists representing European linguistic minorities. Berlin: Peter Lang.

Duff, Patricia A. 2008. Heritage language education in Canada. In: Brinton, Donna M., Kagan, Olga and Bauckus, Susan, eds. Heritage language education. New York: Routledge, 71-90.

Duranti, Alessandro. 1997. Linguistic anthropology. Cambridge: Cambridge University Press.

Eckert, Penelope. 2014. Ethics in linguistic research. In: Podesva, Robert J. and Sharma, Devyani, eds. Research methods in linguistics. Cambridge: Cambridge University Press, 11-26.

ELDIA 2014 Laakso, Johanna, Sarhimaa, Anneli, Spiliopoulou Åkermark, Sia, Toivanen, Reetta: Summary of the research project ELDIA (European Language Diversity for All) Available: https://services.phaidra.univie.ac.at/api/object/o:304813/diss/Content/get Accessed: 30 November, 2019.

Eriksen, Thomas H. 1993. Ethnicity and nationalism. London: Pluto Press.

Fejes, László. 2010. A Narikari-szindróma [The Narikari syndrome]. In: Csernicskó, István, ed. Utazás a magyar nyelv körül [Traveling around the Hungarian language]. Budapest: Tinta, 191-195. 
Fenyvesi, Anna. 2014. Endangered languages in the digital age: Supporting and studying digital language use in them, Finnisch-Ugrische Mitteilungen, 38: 255-270.

Fishman, Joshua A. 1991. Reversing language shift. Clevedon: Multilingual Matters.

Fishman, Joshua A. 2001a. Why is it so hard to save a threatened language? In: Fishman, Joshua, ed. Can threatened languages be saved? Reversing language shift. Clevedon: Multilingual Matters, 1-22.

Fishman, Joshua A. 2001b. 300-plus years of heritage language education in the United States. In: Peyton, J., Renard, D., McGinnis, S, eds. Heritage languages in America: Preserving a national resource. Washington: Center for Applied Linguistics, 81-98.

García, Ofelia. 2008. Bilingual education in the 21st century. Oxford: Wiley-Blackwell.

García, Ofelia, Zakharia, Zeena, and Otcu, Bahar, eds. 2013. Bilingual community, education and multilingualism: Beyond heritage languages in a global city. Clevedon: Multilingual Matters.

Geertz, Clifford. 1973. Thick Description: Towards an interpretive theory of culture. In: Geertz, Clifford: The interpretation of cultures. New York: Basic Books. 3-30.

Glavatskaya, Elena, 1996. Christianization = Russification? On preserving the religious and ethnic identity of the Ob-Ugrians. In: Pentikäinen, Juha, ed. Shamanism and northern ecology. Berlin - New York: Mouton de Gruyter, 373-386.

Grenoble, Lenore A. and Whaley, Lindsay J. 2006. Saving languages: An introduction to language revitalization. Cambridge: Cambridge University Press.

Grenoble, Lenore A. 2011. Language ecology and endangerment. In: Austin, Peter K. and Sallabank, Julia, eds. The Cambridge handbook of endangered languages. Cambridge: Cambridge University Press, 27-44.

Grinevald, Colette and Bert, Michael. 2011. Speakers and communities. In: Austin, Peter K. and Sallabank, Julia, eds. The Cambridge handbook of endangered languages. Cambridge: Cambridge University Press, 45-65.

Grosjean, François. 1982. Life with two language: An introduction to bilingualism. Cambridge: Harvard University Press.

Hale, Ken. 1992. Endangered languages: On endangered languages and the safeguarding of diversity. Language 68(1): 1-44.

Hinton, Lianne. 2011. Revitalization of endangered languages. In: Austin, Peter K. and Sallabank, Julia, eds. The Cambridge handbook of endangered languages. Cambridge: Cambridge University Press, 291-311. 
Honti, László. 1998. Die wogulische Sprache. In: Sinor, Denis, ed. The Uralic languages: Description, history and foreign influences. Handbuch des Orientalistik 8/1, Leiden: Brill, 147-171.

Hornberger, Nancy H. and Wang, Shuhan C. 2008. Who are our heritage language learners? Identity and biliteracy in heritage language education in the United States. In: Brinton, Donna M., Kagan, Olga and Bauckus, Susan, eds. Heritage language education. New York: Routledge, 3-35.

Hornsby, Michael. 2015. Revitalizing minority languages: New speakers of Breton, Yiddish and Lemko. New York: Palgrave Macmillan.

Hornsby, Michael and Vigers, Dick. 2012. Minority semiotic landscapes: An ideological minefield? In: Gorter, Durk, Marten, Heiko F., and Van Mensel, Luk, eds. Minority languages in the linguistic landscape. PLACE: Palgrave Macmillan, 1-18.

Horváth, Csilla. 2010a. Élö patak: Egy manysi revitalizációs kísérlet bemutatása [Living creek: Introducing a Mansi language revitalisation attempt]. Szeged: University of Szeged, MA thesis.

Horváth, Csilla. 2010b. Szent helyek Hanti-Manszijszkban: A szekularizáció és a szakralizáció a legújabb kori manysi vallási szokásokra [Sacred places in Khanty-Mansiysk: The impact of secularisation and sacralisation on contemporary Mansi religious habits]. Szeged: University of Szeged, MA thesis.

Horváth, Csilla. 2012 A nyelvi kontaktusok hatása a manysi revitalizációs törekvésekre [The effects of language contacts on the Mansi revitalization attempts]. In: Váradi, Tamás, ed. VI. Alkalmazott Nyelvészeti Doktoranduszkonferencia $\left[6^{\text {th }}\right.$ Conference in applied linguistics for PhD-students]. Budapest. 62-68. Available: http://www.nytud.hu/alknyelvdok12/proceedings12/horvath2012.pdf, Accessed: 8 March, 2013.

Horváth, Csilla. 2016. A manysi örökségnyelv oktatási kísérletei és eredményei [Attempts and results in Mansi heritage language education]. Általános Nyelvészeti Tanulmányok, 28: 295-306.

Horváth, Csilla, Szilágyi, Norbert, Vincze, Veronika and Nagy, Ágoston. 2017. Language technology resources and tools for Mansi: An overview. In: Tyers, Francis M., Rießler, Michael, Pirinen, Tommi A. and Trosterud, Trond, eds. Proceedings of The 3rd International Workshop for Computational Linguistics of Uralic Languages. Stroudsburg: The Association for Computational Linguistics, 56-65. 
Horváth, Csilla. 2019. The "extraordinary thing": The only Mansi newspaper on online presence and social media practice. In: Pralica, Dejan and Šinković, Norbert, eds. Digitalne medijske tehnologije i društveno-obrazovne promene 8. Novi Sad: Univerzitet u Novom Sadu, 165-176.

Hunfalvy, Pál. 1872. Máté evangéliuma: A' tobolszki kormányzóságbeli kondai vogulok nyelvére leforditotta Popov G. [Gospel of Matthew: Translated into the language of the Konda Vogul in the Tomsk governorate by G. Popov]. Pest: Hoffmann és Molnár.

Huss, Leena M. 1999. Reversing language shift in the far north: Linguistic revitalization in Northern Scandinavia and Finland. Uppsala: Uppsala Universitet.

Jakobson, A 1935 Lui mat olne mir. Leningrad:. Detgiz

Janicki, Karol. 2004. The sociology of language. In: Wiegand, Herbert Ernst, ed. Sociolinguistics. HSK 3.1. New York: Walter de Gruyter, 67.

Jaworski, Adam and Thurlow, Crispin. 2010. Semiotic landscapes. London: Continuum.

Jääsalmi-Krüger, Paula. 1998. Khanty language and lower school education: Native, second or foreign language? In: Kasten, Erich, ed. Bicultural education in the North. Münster: Waxmann, 101-112.

Kannisto, Artturi and Nevalainen, Jorma. 1970. Statistik über die Wogulen. Journal de la Société Finno-Ougrienne, 70: 1-95.

Kálmán, Béla. 1976. Chrestomathia Vogulica. Budapest: Tankönyvkiadó.

Keresztes, László. 1998. Mansi. In: Abondolo, Daniel, ed. The Uralic languages. London: Routledge, 387-427.

KMNS HMAO 2019 Информация по вопросу сохранения, развития, популяризации родных языков коренных малочисленных народов Севера в Ханты-Мансийском автономном округе - Югре. Available: https://kmns.admhmao.ru/obrazovanie/rodnye-yazyki-korennykh-malochislennykh-narodov-severa/3994758/informatsiyapo-voprosu-sokhraneniya-razvitiya-populyarizatsii-rodnykh-yazykov-korennykhmalochislen Accessed: 29 December, 2019.

Kornai, András. 2013. Digital language death. PLoS ONE 8(10). Available: https://doi.org/10.1371/journal.pone.0077056 Accessed: 23 May, 2014.

Krauss, Michael. 1997. The indigenous languages of the North: A report on their present state. Northern minority languages: Problems of survival. Senri Ethnological Studies, 44:134.

Krohn, Julius. 1908 A finnugor népek pogány istentisztelete [The pagan worship among the Finno-Ugric peoples]. Budapest: Magyar Tudományos Akadémia, 
Landry, Rodrigue and Bourhis, Richard Y. 1997. Linguistic landscape and ethnolinguistic vitality: An empirical study. Journal of Language and Social Psychology, 16 (1): 2349.

Letenyei, László. 2005. Településkutatás [Settlement studies]. Budapest: L’Harmattan - Ráció Kiadó

Levon, Erez. 2014. Ethnography and recording interaction. In: Podesva, Robert J. and Sharma, Devyani, eds Research methods in linguistics. Cambridge: Cambridge University Press, 195-215.

Lewis, M. Paul and Simons, Garry F. 2010. Assessing endangerment: Expanding Fishman's GIDS, Romanian Review of Linguistics, 55: 103-120.

Marten, Heiko F., Van Mensel, Luk and Gorter, Durk, 2012. Studying minority languages in the linguistic landscape. In: Gorter, Durk, Marten, Heiko F. and Van Mensel, Luk, eds. Minority languages in the linguistic landscape. Basingstoke: Palgrave Macmillan, 1-18. Mesthrie, Rajend. 2011. Introduction: The sociolinguistic enterprise. In: Mesthrie, Rajend, ed. The Cambridge handbook of sociolinguistics. Cambridge: Cambridge University Press, $1-14$.

Montrul, Silvina. 2016. The acquisition of heritage languages. Cambridge: Cambridge University Press.

Moriarty, Máiréad. 2011. New roles for endangered languages. In: Austin, Peter K. and Sallabank, Julia, eds. The Cambridge handbook of endangered languages. Cambridge: Cambridge University Press, 446-458.

Munkácsi, Bernát. 1889. Nyelvészeti tanúlmányútam a vogulok földén 1 [My field trip in the land of the Voguls 1]. Budapesti szemle, 60: 206-237.

Munkácsi, Bernát. 1894. A vogul nyelvjárások szóragozásukban ismertetve [The Vogul dialects presented through declination and conjugation]. Budapest: MTA.

Muth, Sebastian. 2016. Street art as commercial discourse: Commercialization and a new typology of signs in the cityscapes of Chisinau and Minsk. In: Blackwood, Robert, Lanza, Elizabeth and Hirut, Woldemariam, eds. Negotiating and contesting identities in linguistic landscapes. London: Bloomsbury, 19-36. 
Nagy, Naomi and Sharma, Devyani. 2014. Transcription. In: Podesva, Robert J. and Sharma, Devyani, eds. Research methods in linguistics. Cambridge: Cambridge University Press, 235-256.

Nagy, Zoltán. 2007. Az öseink még hittek az ördögökben: Vallási változások a vaszjugani hantiknál [Our ancestors still believed in devils: Changes in religion among the Vasyugan Khanty]. Budapest: MTA Néprajzi Kutatóintézete - Pécsi Tudományegyetem Néprajz - Kulturális Antropológia Tanszéke -L’Harmattan

Nagy, Zoltán. 2016. Szibéria néprajza és a város: Akik kimaradtak az összefoglalókból [The ethnography of Siberia and the city: The people forgotten in the summaries]. In: Szeverényi, Sándor and Szécsényi, Tibor, eds. Érdekes nyelvészet [Interesting linguistics]. Available: http://ling.bibl.u-szeged.hu/erdekes/05-NagyZ.pdf Accessed: 29 April, 2016.

Nagy, Zoltán. 2020. Egy folyó több élete. Hantik és oroszok a nyugat-szibériai Vaszjugán folyó mentén [The several lives of one river: Khanties and Russians along the Vasyugan river in Western Siberia]. manuscript

Németh, Szilvia. 2018. A manysi kódváltások osztályozása [The types of code-switching used by Mansi speakers]. In: Csepregi, Márta and Salánki, Zsuzsa, eds. A többnyelvüség megnyilvánulásai finnugor nyelvü közösségekben [The dynamics of multilingualism in Finno-Ugric communities]. Budapest: ELTE BTK Finnugor Tanszék, Numi-Tórem Finnugor Alapítvány, 81-114.

Olthuis, Marja-Liisa, Kivelä, Suvi, and Skutnabb-Kangas, Tove. 2013. Revitalizing indigenous languages: How to recreate a lost generation. Clevedon: Multilingual Matters.

Ostler, Nicholas. 2011. Language maintenance, shift, and endangerment. In: Mesthrie, Rajend, ed. The Cambridge handbook of sociolinguistics. Cambridge: Cambridge University Press, 315-334.

Pasanen, Annika. 2003. Kielipesä ja revitalisaation. Karjalaisten ja inarisaamelaisten kielipesätoiminta.

Available: https://helda.helsinki.fi/bitstream/handle/10138/19690/kielipes.pdf, Accessed: 2 May, 2020 .

Pasanen, Annika. 2015. Kuávsui já peeivičuovâ 'Sarastus ja päivänvalo' Inarinsaamen revitalisaatio. Helsinki: Unigrafia Oy.

Paulston, Christina Bratt, Pow Chee Chen, and Connerty, Mary C. 1993. Language regenesis. A conceptual overview of language revival, revitalization and reversal. Journal of Multilingual and Multicultural Development, 14(4): 275-286. 
Polinsky, Maria. 2018. Heritage languages and their speakers. Cambridge: Cambridge University Press

Polinsky, Maria and Kagan, Olga. 2007. Heritage languages: in the "wild" and in the classroom. Languange and Linguistic Compass, 1: 368-395.

Pusztay, János. 2006. Nyelvével hal a nemzet [A nation dies with its language]. Budapest: Teleki László Alapítvány.

Resolution 217 A (III). Universal Declaration of Human Rights. Available: https://kmns.admhmao.ru/dokumenty/rf/300606/, Accessed: 17 September, 2014.

Resolution 61/29. Declaration on the Rights of Indigenous Peoples. Available: https://kmns.admhmao.ru/dokumenty/rf/300611/, Accessed: 17 September, 2014.

Riese, Timothy. 2001. Vogul. PLACE: Lincom Europa.

Sallabank, Julia. 2011. Language policy for endangered languages. In: Austin, Peter K. and Sallabank, Julia, eds. The Cambridge handbook of endangered languages. Cambridge: Cambridge University Press, 277-290.

Schilling, Natalie. 2014. Surveys and interviews. In: Podesva, Robert J. and Sharma, Devyani, eds. Research methods in linguistics. Cambridge: Cambridge University Press, 96-115.

Schmidt, Éva. 2006. Nyelv, nyelvjárás, írásbeliség, irodalom [Language, dialect, literacy, and literature]. Budapest: MTA Nyelvtudományi Intézet.

Siikala, Anna-Leena, Napolskikh, Vladimir, and Hoppál, Mihály, eds. 2008. Mansi mythology. Budapest - Helsinki: Akadémiai Kiadó - Finnish Literature Society

Sipos, Mária. 2004. Veszélyeztetett nyelvek - emberi jogok [Endangered languages and human rights]. Finnugor Világ, 9(3) 16-24.

Sipos, Mária. 2006. A hanti újságírás nyelvéröl [On the language of Khanty journalism]. Folia Uralica Debreceniensia, 13: 103-116.

Sipőcz, Katalin. 2005. www.perepis2002.ru. Finnugor Világ, 10(2): 23-27.

Sipőcz, Katalin. and Dolovai, Dorottya. 2001. A vogulok (manysik) [The Voguls (Mansi)]. In: Csepregi, Márta, ed. Finnugor kalauz [Finno-Ugric guide]. Budapest: Panoráma, 48-59.

Skribnik, Elena and Koshkaryova, Natalya. 2006. Khanty and Mansi: The contemporary linguistic situation. In: Pentikäinen, Juha, ed. Shamanism and northern ecology. The Hague: Mouton de Gruyter, 207-218.

Skutnabb-Kangas, Tove and Phillipson, Robert. 1994. Linguicide. In: Asher, Ronald E and Simpson, James M. Y., eds. The encyclopedia of language and linguistics. New York: Pergamon Press \& Aberdeen University Press, 2211-2212. 
Skutnabb-Kangas, Tove, Philipson, Robert, Mohanty, Ajit K. and Panda, Minati, eds. 2009.

Social justice through multilingual education. Clevedon: Multilingual Matters.

Śernecov, Valerij 1932 Ilpi L,oyhh. Moskva - Leningrad: Ucpedgiz.

Śrnecov, Valerij 1934 Lovintane mages kniga. Moskva - Leningrad: Ucpedgiz.

Szalontai-Dmitrijev, [sic!] Judit. 2005. Magyartanítás Hanti-Manszijszkban [Teaching Hungarian in Khanty-Mansiysk]. Finnugor Világ, 10(4): 19-22.

Szokolszky, Ágnes. 2004. Kutatómunka a pszichológiában [Research in psychology]. Budapest: Osiris.

Tambi, Vladimir. 1937. Elmholas numbl jalujkve humḷe haņsuvlas. Moskva-Leningrad: Komsomol Centr Komitet N̦avram Kniga Varmaḷ.

Touluze, Eva. 1999. The development of a written culture by the aboriginal peoples of Western Siberia. Arctic Studies 2, Pro Ethnologia 7: 53-85. Available http://kodu.ut.ee/ roma1956/images/stories/artiklid/the\%20development\%20of\%20a \%20writing1998.pdf. Accessed: 22 June, 2019.

Trudgill, Peter. 2004. Sociolinguistics: An overview. In: Wiegand, Herbert Ernst, ed. Sociolinguistics. HSK 3.1. New York: Walter de Gruyter, 1-5.

UNESCO 2003 Language vitality and endangerment. Document submitted to the International Expert Meeting on UNESCO Programme Safeguarding of Endangered Languages. Paris, 10-12 March 2003 Available: http://www.unesco.org/new/fileadmin/MULTIMEDIA/HQ/CLT/pdf/Language_vitalit y_and_endangerment_EN.pdf Accessed: 4 March, 2019.

UNESCO 2011 UNESCO’s Language Vitality and Endangerment Methodological Guideline: Review of Application and Feedback since 2003. Available: http://www.unesco.org/new/fileadmin/MULTIMEDIA/HQ/CI/CI/pdf/unesco_languag e_vitaly_and_endangerment_methodological_guideline.pdf Accessed: 4 March, 2019. Valdés, Guadalupe. 2001. Heritage language students: profiles and possibilities. In: Peyton, J., Renard, D., McGinnis, S, eds. Heritage languages in America: Preserving a national resource. Washington: Center for Applied Linguistics, 37-77.

Ventsel, Aimar. 2009. Introduction: Generation P in the tundra. Young People and the Russian North. Folklore, 41: 9-32.

Ventsel, Aimar and Dudeck, Stephan. 1998. Do the Khanty need a Khanty curriculum? In: Kasten, Erich., ed. Bicultural education in the North. Münster: Waxmann, 89-100. 
Virtanen, Susanna. 2020. A word-formational approach to neologisms in modern Northern Mansi: Bilingual compound names of professions, documents and institutions. Studia Uralo-altaica, 54: 2-13.

Wardhaugh, Ronald. 2006. An introduction to sociolinguistics. Oxford: Whiley-Blackwell.

Webb, John B. and Miller, Barbara L. 2000. Teaching heritage learners: Voices from the classroom. Yonkers: American Council on the Teaching of Foreign Languages.

Zamyatin, Konstantin. 2012. The education reform in Russia and its impact on teaching of the minority languages: An effect of nation-building? Journal on Ethnopolitics and Minority Issues in Europe, 11(1): 17-47.

Zamyatin, Konstantin. 2014. An official status for minority languages? A study of state languages in Russia's Finno-Ugric republics. Helsinki: Suomalais-Ugrilainen Seura.

Zamyatin, Konstantin. 2017. Indigenous peoples and education in the Russian Federation. State of the World's Indigenous Peoples, 3: 187-206.

Zamyatin, Konstantin. 2018. A Russian-speaking nation? The promotion of the Russian language and its significance for ongoing efforts at the Russian nation-building. In: Grin, François and Kraus, Peter A., eds. The politics of multilingualism: Linguistic governance, globalisation and Europeanisation. Amsterdam: John Benjamins, 39-64.

Zuḷov, P.N. 1933. Lovintan małbs kniga. Moskva-Leningrad: Uçpedgiz.

Арефьев Александр Леонардович. 2018. Социология языка. Языки коренных малочисленных народов Севера, Сибири и Дальнего Востока. Москва: Юрайт.

Афанасьева, Клавдия Васильевна. 2013. Мансийская азбука. Санкт-Петербург: ООО «Альмаз-Граф».

Афанасьева, Клавдия Васильевна and Акбаш, Елена Устиновна. 2007. Словарь-минимум по мансийскому языку для 1-4 классов общеобразовательных учреждений. Ханты-Мансийск: Полиграфист.

Баландин, Алексей Николаевич. 1964. Маньси букварь. Маньси латың учебник. МоскваЛенинград: Издательство «Просвещение».

Бударин, Михаил Ефимович. 1952. Прошлое и настоящее народов Северо-Западной Сибири. Омск: Омское областное государственное издательство

В городе Якутске открывается «языковое гнездо» для юкагиров. Available: http://yakutiakmns.org/archives/7945 Accessed: 30 March, 2020.

В Коми двенадцать детских садов превратятся в «языковые гнезда». Available: https://komiinform.ru/news/75625/, Accessed: 30 March, 2020. 
Владыкин, Владимир Емельянович and Розенберг Наталия Абрамовна 2004. Этнофутуризм: воспоминание о будущем? In: Владыкин, Владимир Емельянович, ed. Удмуртская мифология. Ижевск: Удмуртия, 146-158.

Гайдар, Аркадий Петрович. 1955. Тимур ос тав командатэ. Ленинград: Учпедгиз.

Гемуев Измаил Нухович and Сагалаев Андрей Маркович 1986. Религия народа манси. Новосибирск: Издательство «Наука».

Герасимова, Дина Васильевна. 2004. Мансийский язык в таблищах. Пособие для учащцихся 5-9 классов общееоразовательных учреждений. Санкт-Петербург: Филиал издательства «Просвещения»

Герасимова, Светлана Алексеевна. 2015. Мансийский язык. 2 класс. Tесты. ХантыМансийск: Югорский формат.

Герасимова, Светлана Алексеевна, Динисламова Светлана Селиверстовна and Кумаева Мария Владимировна. 2016. Сборник олимпиадных заданий по мансийскомй языку. Ханты-Мансийск: ООО «Формат»

Гончарова, Елена Владимировна and Мулчанов, Рустам Равильевич. 2005. Tресколье. Сургут: ООО Минэлла.

Демографические процессы. 2013. Коренные малочисленние народы ХантьМансийского Автономного Округа - Югры: История и расселение. http://www.kmns.admhmao.ru/wps/portal/kmn/home/istoriya_i_rasselenie Date of access: 13 October, 2013.

«Древо мудрости» манси. Available: https://ugra-news.ru/article/drevo_mudrosti_mansi/

Accessed: 23 November, 2020

Динисламова, Светлана Селиверстовна. 2004. Витсам. Ханты-Мансийск: Полиграфист.

Динисламова Светлана Селиверстовна. 2014. Занимательная математика на мансийском языке. Ханты-Мансийск: Югорский формат.

Динисламова, Светлана Селиверстовна. 2015. Ма̄ньщи литература о̄вылтыт. Вестник угроведения, 22(3): 32-35.

Динисламова, Светлана Селиверстовна. 2017. Нйврамыт, па̄ща о̄лэ̄н. Bитсам 3(1): 3.

Епископ Никанор. 1903. Азбука для вогул приуральских. Москва: Синодальная Типография

Закон о реестре коренных малочисленных народов принят во втором чтении! Available: http://www.raipon.info/info/news/4093/ Accessed: 3 February, 2020.

Иностранец? Снимай часы! троицкий вариант Available: https:/trvscience.ru/2019/08/13/inostranec-snimaj-chasy/ Accessed: 29 November, 2019. 
Карьялаинен, К. Ф. 1995. Религия обско-угорских народов 2. Томск: Издательство Томского университета.

Конькова, Анна Митрофановна. 1991. Элт миныл Ивыр. Свердловск: Среднеуральское книжное издательство

Кумаева, Мария Владимировна - Нахрачева Галина Леонидовна. 2014а. Занимательная грамматика мансийского языка 2. Ханты-Мансийск: Югорский формат.

Кумаева, Мария Владимировна - Нахрачева Галина Леонидовна. 2014b. Занимательная грамматика мансийского языка 3. Ханты-Мансийск: Югорский формат.

Кумаева, Мария Владимировна, Нахрачева Галина Леонидовна, and Шиянова Анастасия Антоновна. 2015. Мансийский язык. 5 класс. Тесты для обобщающегго контроля. Ханты-Мансийск: Югорский формат.

Кумаева, Мария Владимировна and Соловар Валентина Николаевна. 2015а. Мансийский язык. 5 класс. Проверочные работы. Ханты-Мансийск: Югорский формат.

Кумаева, Мария Владимировна and Соловар Валентина Николаевна. 2015b. Мансийский язык. 5 класс. Дидактический материал. Ханты-Мансийск: Югорский формат.

Кумаева, Мария Владимировна and Шиянова Анастасия Антоновна. 2014a Занимательная грамматика мансийского языка 1. Ханты-Мансийск: Югорский формат.

Кумаева, Мария Владимировна and Шиянова Анастасия Антоновна. 2014b. Занимательная грамматика мансийского языка 4. Ханты-Мансийск: Югорский формат.

Кумаева, Мария Владимировна, Шиянова Анастасия Антоновна, and Нахрачева Галина Леонидовна. 2014. Занимательная грамматика мансийского языка 5. ХантыМансийск: Югорский формат.

Лалаева, Майя Ефимовна. 2005. Мансийский язык в соииокультурном пространстве Югры. Available: http://lingsib.iea.ras.ru/ru/round_table/papers/lalaeva.shtml Accessed: 29 September, 2014.

Иванова, В. С. 2000. Марк хум хансум ёмас лйххал. Helsinki-Stockholm: Institute for Bible Translation.

Маленькие югорчане воспитываются в «языковых гнездах. Available: https://ugra.mk.ru/amp/social/2019/04/02/malenkie-yugorchane-vospityvayutsya-vyaykovykh-gnezdakh.html Accessed: 30 March, 2020.

Матпіинэл и Маркнэл елпынг евангеліи 1882 Гельсингфорсъ: Типографія Финскаго Литературнаго Общества. 
Маяковский, Владимир Владимирович. 1955. Манырман ёмас, манырман люль. Ленинград: Учпедгиз.

Министр культуры РФ: «Финно-угорские народы России - это часть русского мира. Available: http://finugor.ru/node/24548, Accessed: 30 March, 2020

Нахрачева Галина Леонидовна, Шиянова Анастасия Антоновна, and Кумаева Мария Владимировна. 2012. Мансийский язык 1-4 классы: Тесты для обобщающего контроля. Ханты-Мансийск: Издательский дом «Новости Югры».

Необходимо вернутся к практике «языковых гнезд» для сохранения языков коренных народов Югры. Available: http://www.finnougoria.ru/news/publications/57201/ Accessed: 30 March, 2020.

Новая линия учебных пособий для юных манси появится в школах к началу учебного года. 2017. Просвещение. Available: https://prosv.ru/news/show/3148.html, Accessed: 11 April, 2019.

Норова, Ольга Мартыновна. 2010. Мансийский в картинах. «Учимся читать». ХантыМансийск.

Норова, Ольга Мартыновна. 2011. «Вит сам». Образовательная программа для детей дошкольного возраста. Ханты-Мансийск.

Опыт Красноярского края в сфере дошкольного образования для детей из числа коренных народов. Available: http://www.raipon.info/kids/krasnoyar_krai.php, Accessed: 30 March, 2020.

Опыт Ханты-Мансийского автономного округа - Югры в сфере дошкольного обрпзования детей из числа коренных народов Севера. Available: http://www.raipon.info/kids/khanty man aut okr.php Accessed: 30 March, 2020.

Панченко Людмила Николаевна. 2013. Мансийская азбука. Ханты-Мансийск: Издательство ... [sic!].

Попова, Светлана Алексеевна. 2001. Са̄ль уррнэ ойка мо̄йтыт. Томск: Издательство Томского университета.

Попова, Светлана Алексеевна. 2003. Обряды перехода в традиционной культуре манси. Томск: Издетельство Томского Университета.

Попова, Светлана Алексеевна - Ромбандеева Светлана Матвеевна. 2010. Ворраян ма̄хум мо̄йтыт. Ханты-Мансийск: Печатное дело.

Программа по сохранению языков ханты и манси разрабатывается в Югре. Available: https://t-1.ru/92670.html Accessed: 30 March, 2020. 
Проект «языковое гнездо» заинтересовал в НАО учителей ненецкого языка. Available: http://finugor.ru/node/22568 Accessed: 30 March, 2020

Рещетникова, Раиса Германовна. 2015. Ща̄нь ла̄тныт элаль тотавет. Available: http://www.khanty-yasang.ru/luima-seripos/no-91099/2961 Accessed: 30 March, 2020.

Ромбандеева, Евдокия Ивановна. 1960. Методические указания к учебнику родного языка. Ленинград: Государтсвенное учебно-педагогическое издетельство министерства просвещения РСФСР Ленинградское отделение.

Ромбандеева, Евдокия Ивановна, and Вахрушева, Матрена Панкратьевна. 1984. Мансийский язык. Ленинград: Просвещение.

Ромбандеева, Евдокия Ивановна. 2005. Русско-мансийский словарь. Санкт-Петербург: Миралл.

Ромбандеева, Евдокия Ивановна. 2004. Йис порат ма̄ньси ма̄хум семьят ва̄рыглам писяныл. In: Ромбандеева, Евдокия Ивановна and Харамзин Терентий Герасимович, eds. Сохранение традиционной культуры коренных малочисленных народов Севера и проблемы устойчивого развития: материалы международной научной-практической конференции. Москва: Икар, 220-223.

Сайнахова, Анастасия Ильинична. 2001. Ма̄ньси ла̄mыıу 2. Мансийский язык. Учебник для 2 класса. Санкт-Петербург: Филиал издательства «Просвещение».

Светлой памяти, Герой. 2020. Ханты-Манси Мир. Available: http://www.khantyyasang.ru/news/9856 Accessed: 2 February, 2020.

Секей, Габор. 2012. Экспедиции к ивдельским манси. Вопросы ономастики, 12(1): 95101.

Систему учета представителей коренных малочисленных народов Севера создадут в Юrpe. TACC, 2017. június 15. https://tass.ru/obschestvo/4337641 Accessed: 29 November, 2019.

Скачко, Анатолий Евгеневич. 1931 Земля Югорская и Обдорская в лето 1930. г. (Историческая справка). Советский Север 1931/2 58-113.

Слинкина, Татьяна Дмитриевна. 2013. Кар ос осься урығу ю̄нтуn. Ханты-Мансийск: Юграфика.

Соловар, Валентина Николаевна and Кумаева Мария Владимировна. 2012. Мансийский язык. Тестовые задания. Ханты-Мансийск: Югорский формат.

Сподина, Виктория Ивановна 2011. Ханты-Мансийский автономный округ: этнические языки в вузах и школах регионах. In: Тишков, Валерий Александрович, ed. 
Правовой статус финно-угорских языков и этнокультурные потребности российской школьы. Москва: Этноконсалтинг, 211-240.

Торгашин, Я. 1940. М. Горький. Перевели на мансийский язык П. Чейматов и И. Яркин под редакцией В. Чернецова. Ленинград: Государственное учебно-педагогическое издательство Наркомпроса РСФСР.

Хакназаров, Саидмурод Хамдамович. 2013. Родные языки коренных народов Нефтеюганского района Югры в контексте социологических исследований. Вестник угроведения, 3(1): 82-90.

Чепреги, Марта. 2017. Сургутский диалект хантыйского языка. Ханты-Мансийск: ОУИПИиР

Чернецов, Валерий Николаевич. 1933. Книга для чтения. Часть первая. Перевод с мансийского языка В.Н. Чернецова. Ленинград: Учпедгиз.

Чернецов, Валерий Николаевич. 1937. Мансийский (вогульский) язык. In: Прокофьев, Георгий Николаевич, ed.: Языки и письменность народов Севера I. МоскваЛенинград: Государственное учебно-педагогическое издательство. 163-182.

Чернецов, Валерий Николаевич and Чернецова Ирина Яковлевна. 1936. Краткий мансийско-русский словарь. Москва - Ленинград: Учпедгиз.

Чтоб родной язык не стал «латынью». Ямальцев заинтересовала идея «языковых гнезд». Available: $\quad$ https://sever-press.ru/2019/08/09/chtob-rodnoj-jazyk-ne-stal-latynjujamalcev-zainteresovala-ideja-jazykovyh-gnezd/amp/ Accessed: 30 March, 2020.

Шафранов-Куцев, Геннадий Филиппович, ed. 2000. Югория. Энщиклопедия ХантыМансийского автономного округа I-III. Ханты-Мансийск: Сократ.

Шесталова, Елена Владимировна. 2011. Изучение родного языка и литературы в школах с этнокультурной составляющей образования 01.09.2011 год. Available: http://doinhmao.ru/KMNS/stat/. Accessed: 17 May, 2014.

Шесталова, Елена Владимировна. 2012. Изучение родного языка и литературы в школах c этнокультурной составляющей образования 01.09.2012 год. Available: http://doinhmao.ru/KMNS/stat/ Accessed: 17 May, 2014.

Шумихин Г. С. and Борисова, Е. П. 1975. Создание материальных и духовных предпосылок для становления нового быта у народов Обского Севера в годы строительства социализма. In: Идеологическая работа партийных организаций Западной Сибири и Урала в условиях строительства сочииалима и коммунизма. Тюмень. 42-61.

Югра - электронный регион. 2014. Международный IT-форум 2014 Югра. 
«Языковые гнезда» для юных манси и ханты откроют в Березовском районе Югры. Available: http://finugor.ru/node/22926 Accessed: 30 March, 2020.

«Языковые гнезда» не разрешены в России, у нас есть свой богатый опыт преподаваний родных языков. Available: http://finugor.ru/news/aleksandr-zhuravskiy-yazykovyegnezda-ne-razresheny-v-rossii-u-nas-est-svoy-bogatyy-opyt, Accessed: 30 March, 2020 .

«Языковые гнезда» появятся в девяти детсадах и школах в Карелии. Available: https://www.gumilev-center.ru/yazykovye-gnezda-poyavyatsya-v-devyati-detsadakhi-shkolakh-v-karelii/. Accessed: 30 March, 2020.

«Языковые гнезда» спасут карельский и вепсский языки? Available: https://stolicaonego.ru/news/182988/, Accessed: 30 March, 2020. 